\title{
DISRUPÇÃO DAS ORFS XF-810, XF-818, XF-1940, XF-2359 E XF-2708 DE Xylella fastidiosa-CVC POSSIVELMENTE RELACIONADAS À PATOGENICIDADE DA BACTÉRIA
}

\author{
SIMONE GUIDETTI GONZALEZ \\ Engenheira Agrônoma
}

Orientadora: Profa. Dra. HELAINE CARRER

\begin{abstract}
Dissertação apresentada à Escola Superior de Agricultura "Luiz de Queiroz", Universidade de São Paulo, para obtenção do tútulo de Mestre em Ciências, Área de concentração: Fisiologia e Bioquímica de Plantas.
\end{abstract}

P I R A C I C A B A

Estado de São Paulo - Brasil

Junho - 2004 
Dados Internacionais de Catalogação na Publicação (CIP) DIVISĀO DE BIBLIOTECA E DOCUMENTAÇĀO - ESALQ/USP

\section{Guidetti Gonzalez, Simone}

Disrupção das ORFs Xf-810, Xf-818, Xf-1940, Xf-2359 e Xf-2708 de Xylella fastidiosa CVC possivelmente relacionadas à patogenicidade da bactéria I Simone Guidetti Gonzalez. - Piracicaba, 2004.

113 p. : il.

Dissertação (mestrado) - - Escola Superior de Agricultura Luiz de Queiroz, 2004.

Bibliografia.

1. Bactérias fitopatogênicas - Patogenicidade 2. Clorose variegada dos citros 3. Enzima microbiana 4. Transformação genética I. Titulo

CDD 589.9

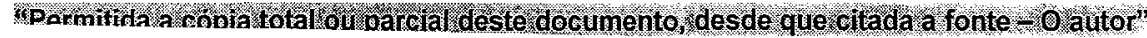




\section{ERRATA}

\begin{tabular}{|c|c|c|c|}
\hline Página & Linha & Onde se lê: & $\begin{array}{l}\text { Leia-se: } \\
\end{array}$ \\
\hline xvi & 11 & $\begin{array}{l}\text {...primer "reverse" que é complementar à } \\
\text { porção 3' do gene }\end{array}$ & $\begin{array}{l}\text {...primer "reverse" que é complementar à } \\
\text { porção 3' de uma seqüência de DNA }\end{array}$ \\
\hline xix & 7 & Variegated Clorose of the citros... & Citrus Variegated Chlorosis... \\
\hline 4 & 24 & ...gram-negativas... & ...Gram-negativas... \\
\hline 7 & 12 & ...Lopes et al. (1999) em São Paulo... & $\begin{array}{l}\text {...Lopes et al. (1999) nas análises } \\
\text { realizadas com amostras do estado de São } \\
\text { Paulo... }\end{array}$ \\
\hline 8 & 12 & ...encurtamento dos internódios... & ...encurtamento dos entrenós... \\
\hline 8 & 21 & $\begin{array}{l}\text {...Este bloqueio dos vasos pelas células } \\
\text { bacterianas é associado com alterações } \\
\text { fisiológicas... }\end{array}$ & $\begin{array}{l}\text {...Sugeriu-se que este bloqueio dos vasos } \\
\text { pelas células bacterianas pode estar } \\
\text { associado com alterações fisiológicas... }\end{array}$ \\
\hline 9 & 15 & ...para detectar raça de $X$. fastidios $\ldots . .$. & $\begin{array}{l}\text {...para detectar linhagem de } X . \\
\text { fastidiosa... }\end{array}$ \\
\hline 12 & 10 & ...ela é incapaz de crescer mais rápido... & $\begin{array}{l}\text {....apresenta baixa velocidade de } \\
\text { replicaçãocelular... }\end{array}$ \\
\hline 12 & 13 & ...mas nutricionalmente diluído... & ...mas nutricionalmente mais pobre... \\
\hline 15 & 17 & $\begin{array}{l}\text {...Na planta, a adesão na parede do } \\
\text { xilema... }\end{array}$ & $\begin{array}{l}\text {...Acredita-se que na planta a adesão na } \\
\text { parede do xilema... }\end{array}$ \\
\hline 16 & 9 & ...100 raças de bactérias... & ...100 linhagens de bactérias... \\
\hline 19 & 13 & ...Actinobacillus... & ...Actinobacillus $\mathrm{sp} .$. \\
\hline 19 & 23 & ...um pedaço desses genes... & ...fragmentos desses genes... \\
\hline 20 & 10 & ... FimA ${ }^{-}$e FimF, estes mutantes... & $\begin{array}{l}\text {... FimA" e FimF" analisado "in vitro". } \\
\text { Estes mutantes... }\end{array}$ \\
\hline 21 & 14 & $\begin{array}{l}\text {...que apesar de ideal é inapropriada, está } \\
\text { no fato de que o desenvolvimento dos } \\
\text { sintomas... }\end{array}$ & $\begin{array}{l}\text {...está no fato de que o desenvolvimento } \\
\text { dos sintomas... }\end{array}$ \\
\hline 24 & 12 & ...é restrito às membranas... & ...é restrito às membranas de pontuação... \\
\hline 28 & 3 & ...exoplissacarídeos... & ...exopolissacarídeos... \\
\hline 28 & 27 & ....MsrA de raças... & ...MsrA de linhagens... \\
\hline 36 & 19 & A transformação dos produtos de ligação... & $\begin{array}{llll}\text { Os produtos de ligação } & \text { foram } \\
\text { transformados... }\end{array}$ \\
\hline 47 & 1 & ...Parafilme... & ...filme PVC... \\
\hline 59 & 18 & $\ldots 11.845 \mathrm{pb} . .$. & $\ldots 8.454$ pb... \\
\hline 60 & $\begin{array}{c}10 \\
\text { (Fig.9) }\end{array}$ & $\ldots 11845 \mathrm{pb} .$. & ...8.454 pb... \\
\hline 71 & 22 & $\begin{array}{l}\text {...Estes resultados demonstram que estas } \\
\text { bactérias apresentam as ORFs alvo } \\
\text { interrompidas pelo gene } y f p \text {, conforme } \\
\text { seus respectivos plasmídeos } \\
\text { transformantes... }\end{array}$ & $\begin{array}{l}\text {...Estes resultados demonstram que estas } \\
\text { bactérias foram transformadas com os } \\
\text { plasmídeos contendo as ORFs alvo } \\
\text { interrompidas pelo gene } y f p . . .\end{array}$ \\
\hline 76 & 27 & $\begin{array}{l}\text {...que se mostrou importante no processo } \\
\text { de manutenção da adesão... }\end{array}$ & $\begin{array}{l}\text {...que hipoteticamente é importante no } \\
\text { processo de manutenção da adesão... }\end{array}$ \\
\hline 82 & 21 & $\ldots 0 \mathrm{Kam}^{K} \ldots$ & ...resistência a canamicina... \\
\hline 83 & 19 & ...ou até mesmo em plantas de citros... & ...ou em plantas de citros... \\
\hline
\end{tabular}


Ao meu avô Alfredo Guidetti (in memoriam), pela sabedoria e exemplo de vida;

Aos meus pais Marcos e Odete, pela minha formação moral e intelectual que permitiram meu desenvolvimento pessoal e profissional, OFEREÇO

Tantas vezes pensamos ter chegado

Tantas vezes é preciso ir além (Fernando Pessoa)

Aos meus dois grandes amores:

Meu marido Gustavo por ser meu porto seguro e pelo incentivo, paciência e amor, E meu filho Gabriel:

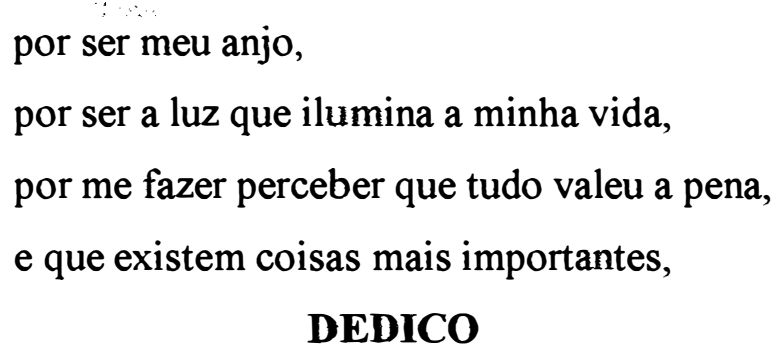




\section{AGRADECIMENTOS}

A força maior, que ilumina o meu caminho.

A ESALQ por me fornecer uma excelente formação acadêmica na graduação e no Mestrado.

A Profa. Helaine Carrer por me abrir às portas da biotecnologia e pela orientação.

Aos meus pais, por todo auxilio e por me ajudarem a cuidar do meu filho desde o início.

A minha sogra Angélica por seu cuidado com meu filho nos intermináveis finais de semana dos últimos meses do Mestrado, nos quais estive ausente.

A toda minha amada família: minha vó Dulce, vó Cacilda, meu irmão Cleyton, meus cunhados e cunhadas, meus primos, tios e meus queridos sobrinhos, pelas alegrias proporcionadas.

A Sílvia Cuco e o Mateus do Depto. de Genética ESALQ/USP, pelo auxílio no uso do microscópio de fluorescência.

A Fundecitrus pelo isolado de Xylella fastidiosa concedido. A Elaine Cristina Martins, técnica da Fundecitrus, pelo seu auxílio no ensino do manuseio da bactéria.

A Renata por iniciar as construções com a ORF Xf-1940.

A todos os estagiários, pós-graduandos e funcionários do CEBTEC, pelo convivio e lições aprendidas, especialmente: Valesca, Henrique, Keine, Carlos, Irving, Solizéte, Amaral, a Fátima pelas construções pVF2 e pVF4 e pelo auxílio constante, e a Danila e o Adriano, companheiros de trabalho nesta jornada. 
A todos os mestrandos do curso de Fisiologia e Bioquímica de Plantas, em especial a todas as estudantes que se tornaram mães e que sabem o quanto é dificil e prazeroso ser mãe e pós-graduanda.

Ao Conselho Nacional de Desenvolvimento Científico e Tecnológico (Cnpq) pela bolsa concedida.

A todos que de forma direta ou indireta auxiliaram neste trabalho.

Ao meu marido e meu filho por compreenderem os momentos em que estive ausente. 


\section{SUMÁRIO}

Página

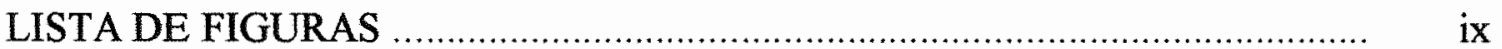

LISTA DE TABELAS …..........................................................................

LISTA DE SIGLAS, ABREVIATURAS E SÍMBLOS...............................

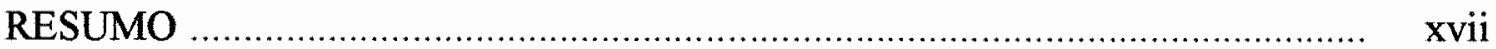

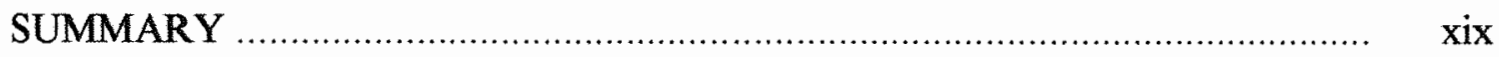

1 INTRODUÇÃO

2 REVISÃO DE LITERATURA........................................................... 3

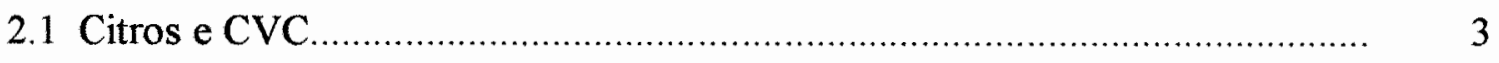

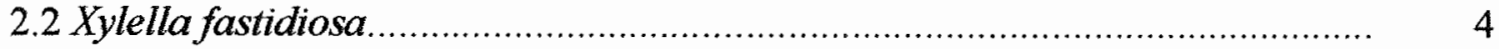

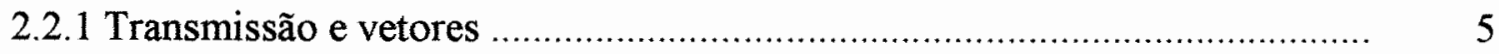

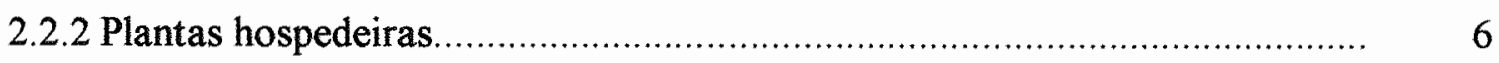

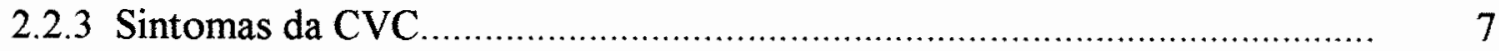

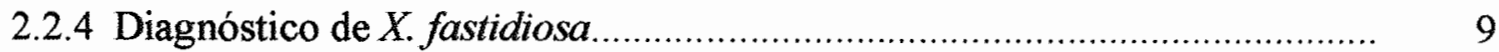

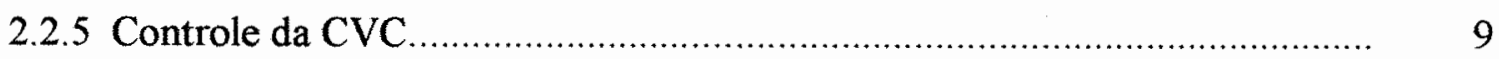

2.2.6 Algumas características do genoma da Xylella fastidiosa .......................... 10

2.3 A utilização de mutações para o estudo funcional de genes............................ 16

2.4 Transformação da bactéria Xylella fastidiosa e obtenção de mutantes............. 18

2.5 Hospedeiros alternativos para o estudo da patogênese de Xylella fastidiosa.... 21

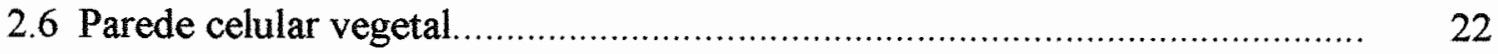

2.7 Fatores relacionados a patogenicidade e enzimas degradadoras da parede

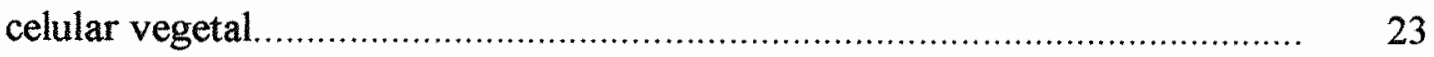

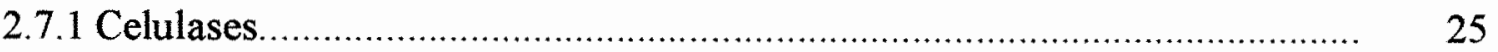




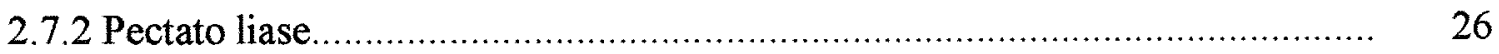

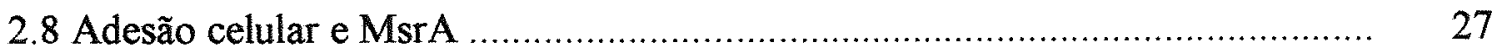

3 MATERIAL E MÉTODOS ............................................................... 30

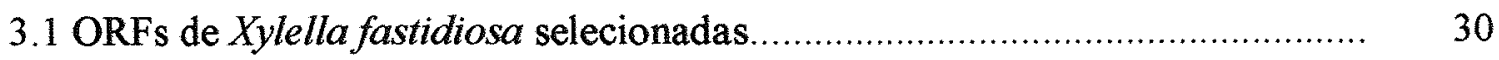

3.2 Extração de DNA cosmidial e plasmidial................................................... 31

3.3 Obtenção das ORFs alvo por Reação em Cadeia da Polimerase (PCR).......... 32

3.4 Clonagem dos fragmentos amplificados por PCR ……................................. $\quad 35$

3.5 Transformação de E. coli com os produtos de ligação........................................ 36

3.6 Construção dos vetores para disrupção de Xylella fastidiosa ........................... 37

3.6.1 Estratégia de disrupção por substituição da ORF pelo gene $y f p \ldots \ldots \ldots \ldots \ldots \ldots \ldots . . . . . . . . . . .37$

3.6.2 Estratégia de disrupção por inserção do cassete $l a c Z-\mathrm{Km}^{\mathrm{R}}$......................... 40

3.7 Confirmação da identidade dos plasmídeos de disrupção de $X$. fastidiosa....... 43

3.8 Análise da expressão dos genes $y f p$ e $l a c Z-\mathrm{Km}^{\mathrm{R}}$ das construções finais em $E$.

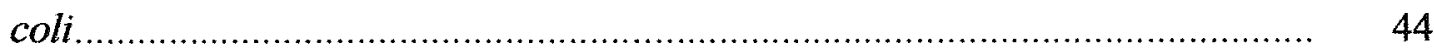

3.9 Cultivo da bactéria Xylella fastidiosa......................................................... 45

3.10 Preparo de células competentes e transformação de Xylella fastidiosa.......... 46

3.11 Extração de DNA de X. fastidiosa ............................................................. 47

3.12 Confirmação do isolado de $X$. fastidiosa ................................................... 48

3.13 Confirmação da obtenção de $X$. fastidiosa transformada ............................... 48

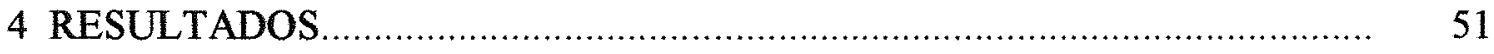

4.1 ORFs alvo selecionadas e as estratégias de disrupção destas ORFs em $X$. fastidiosa..

4.2 Construção dos vetores para disrupção das ORFs por substituição pelo gene $y f p$

4.2.1 PCR e clonagem dos fragmentos 3' e 5' .............................................. 52

4.2.2 Clonagem dos fragmentos 3' em vetor PEYFP-SK ................................... 55

4.2.3 Clonagem dos fragmentos 5' nos vetores pSG3, pSG13, pSG23 e pVF4..... 57

4.3 Construção dos vetores para disrup̧̧ão das ORFs Xf-810 e Xf-1940 utilizando o cassete $l a c Z-\mathrm{Km}^{\mathrm{R}}$ 
4.4 Clonagem da origem de replicação (OriC) de Xylella fastidiosa...................... 62

4.5 Confirmação das construções finais por seqüenciamento ............................... 62

4.6 Análise da expressão dos genes $y f p$ e $l a c Z-\mathrm{Km}^{\mathrm{R}}$ das construções finais em $E$.

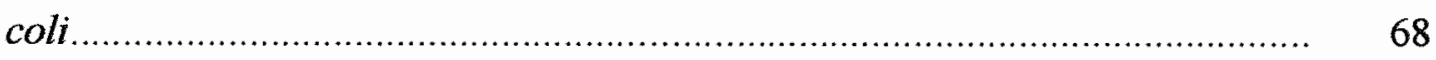

4.7 Confirmação do isolado de $X$. fastidiosa e da obtenção de bactérias mutantes. $\quad 70$

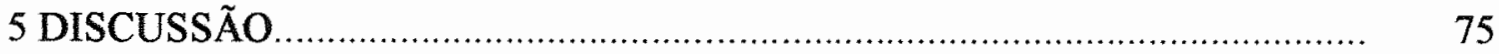

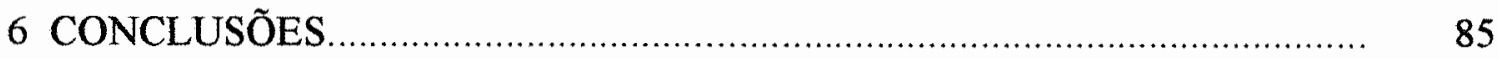

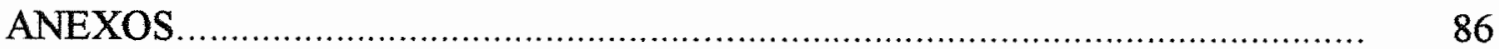

REFERÊNCIAS BIBLIOGRÁFICAS .................................................. 92 


\section{LISTA DE FIGURAS}

1 Esquema para a construção dos plasmídeos vetores para a disrupção das ORFs de Xylella por substituição pelo gene $y f p$. A. Amplificação dos fragmentos 5' e 3' das ORFs de interesse do genoma de $X$. fastidiosa por PCR. B. clonagem dos fragmentos 5' e 3' flanqueando a região codificadora do gene $y f p$ no plasmídeo pEYFP-SK e introdução da OriC de $366 \mathrm{pb}$ do vetor p16Kori. C. Representação do plasmídeo final que foi utilizado na transformação da bactéria $X$. fastidosa.

2 Esquema para a construção dos plasmídeos vetores para a disrupção das ORFs Xf-810 e Xf-1940, utilizando o cassete lacZ-Km ${ }^{\mathrm{R}}$. A. Representação do plasmídeo pKOK6, progenitor do cassete lacZ-Km ${ }^{\mathrm{R}}$. B. Representação dos plasmídeos vetores contendo as ORFs de interesse, demonstrando o sítio interno específico das enzimas de restrição, BgIII ou PstI, local de inserção do cassete lacZ-Km ${ }^{\mathrm{R}}$. C. Demonstração da inserção da OriC de $366 \mathrm{pb}$ ou de 1,9 kb no sítio da BamHI externo à ORF. D. Representação do plasmídeo final para transformação de $X$. fastidiosa.

3 Obtenção dos fragmentos 3' e 5' das ORFs de interesse amplificados através de PCR e separados em gel de agarose $1 \%$. Foram empregados os iniciadores descritos na Tabela 2. Linhas de 1 a 4: apresentam os fragmentos 3' das ORFs Xf-818 (537 pb), Xf-2708 (606 pb), 1940 (603 pb) e Xf-2359 (424 pb). Linhas de 5 a 8: apresentam os fragmentos 5' das ORFs Xf-818 (563 pb), Xf-2708 (540 pb), Xf-1940 (504 pb) e Xf$2359(819 \mathrm{pb}) . \quad \mathrm{M}$ - Marcador de massa molecular $1 \mathrm{~kb}$ plus DNA 
respectivamente, nos plasmidios pSG4, pSG14, pSG25 e pSG57.

9 Confirmação das construções para disrupção utilizando lacZ-Km ${ }^{\mathrm{R}}$. A. Linha 1 pNAW22 digerido com NdeI e HindIII, linha 2 pNAW22 digerido com BglII, linha 3 pSG30 digerido com PstI confirmando a clonagem do lacZ-Km ${ }^{\mathrm{R}}$ (4,7 $\mathrm{kb}$ e $3.612 \mathrm{pb}$ do restante do vetor), linha 4 pSG30 digerido com BamHI (11845 pb). B. Linha 1 fragmento de 1152 pb contendo a ORF Xf-1940 amplificada via PCR. C. Linha 1 pSG50 digerido com BamHI confirmando a presença do inserto de $1.152 \mathrm{pb}$ e do vetor de $2.686 \mathrm{pb}$, linha 2 pSG51 digerido com EcoRV confirmando que a ORF e o LacZ estão na mesma orientação (7.343 pb e 1.228 pb)....

10 Esquemas representando os plasmídeos pSG30 e pSG51. A. Disrupção da ORF Xf-810 pelo cassete lacZ-Km ${ }^{\mathrm{R}}$ (pSG30). B. Disrupção da ORF Xf-1940 pelo cassete lacZ-Km ${ }^{\mathrm{R}}$ (pSG51)

11 Digestão parcial do pSG51. Linha $1-2 \mu \mathrm{L}$ do pSG51 não digerido. Linha 2 - pSG 51 digerido totalmente com BamHI. Linha 3 - pS51 linearizado com Sall. Linhas 4 a 9 digestão parcial do pSG51 com BamHI a $37^{\circ} \mathrm{C}$ por $1,2,5,10,15$ e 30 minutos respectivamente. $\mathrm{M}$ marcador de massa molecular $1 \mathrm{~kb}$ plus DNA Ladder (Gibco BRL).......

12 Confirmação das clonagens da OriC. Linhas 1 a 7 : digestão dos plasmídeos pSG5, pSG15, pSG26, pSG31, pSG52, pSG53 e pSG59 com BamHI confirmando a clonagem da OriC de 366 pb (pSG5, pSG15, pSG26, pSG31, pSG52 e pSG59) ou 1,9 kb (pSG53). M marcador de massa molecular $1 \mathrm{~kb}$ plus DNA Ladder (Gibco BRL).

13 Esquemas representando as plasmídeos finais pSG5, pSG15, pSG26 e pSG57 para a disrupção ORFs Xf-818, Xf-2359, Xf-2708 e Xf-1940 com o gene $y f p$

14 Esquemas representando as plasmídeos finais pSG31, pSG52 e pSG53 para a disrupção ORFs Xf-810 e Xf-1940 com o cassete lacZ-Km ${ }^{\mathrm{R}}$ 
15 Seqüência do quadro aberto de leitura dos plasmídeos pSG5, pSG15, pSG26 e pSG59. O ATG (códon de iniciação da tradução) das ORFs estão no mesmo quadro aberto de leitura com relação ao ATG do gene $y f p$, nos plasmídeos vetores de disrupção de $X$. fastidiosa. O primeiro ATG refere-se a ORF alvo; a seqüência AGATCC refere-se aos sitios $\mathrm{Bg} / \mathrm{II} / \mathrm{BamH}$ I onde as ORFs foram fusionadas; o segundo $\underline{\mathrm{ATG}}$ refere-se ao gene $y f p$

16 Expressão do gene $y f p$ em microscópio de fluorescência. Bactérias contendo os plasmídeos pSG5 (A) e pSG59(B) fluorescendo (aumento de 1000x)

17 Expressão do cassete lacZ- $\mathrm{Km}^{\mathrm{R}}$. Bactérias E. coli contendo os plasmídeos pSG31 (A) e pSG53 (B) que cresceram em meio LB contendo canamicina e produziram um precipitado de cor azul

18 DNA genômico e produto da amplificação do DNA de $X$. fastidiosa com primers CVC1 e CVC272int. Linhas 1 a 6: $2 \mu \mathrm{L}$ de DNA total de seis culturas de Xylella fastidiosa Jla12. Linhas 7 a 12: fragmentos de $500 \mathrm{pb}$ confirmando as culturas de $X$. fastidiosa. $\mathrm{M}$ - marcador de massa molecular $1 \mathrm{~kb}$ plus DNA Ladder (Gibco BRL).

19 Confirmação da presença das ORFs interrompidas pelo gene $y f p$ por PCR. Linhas 1, 3, 5 e 8: DNA de $X$. fastidiosa não transformada utilizando os mesmos primers que para as transformações com os plasmídeos pSG5, pSG15, pSG26 e pSG59, respectivamente (controles negativos). Linha 2: $X$. fastidiosa transformada com pSG5 (681 pb). Linha 4: $X$. fastidiosa transformada com pSG15 (933 pb). Linha 6: $X$. fastidiosa transformada com pSG26 (654 pb). Linha 7: $X$. fastidiosa transformada com pSG59 (637 pb)

20 Confirmação da disrupção das ORFs de $X$. fastidiosa. Linhas $1,4,5,7$, 9 e 11: PCR com DNA de $X$. fastidiosa não transformdas utilizando os 
mesmos primers que para as transformações com os plasmídeos pSG5, pSG15, pSG31, pSG52, pSG53 e pSG59, respectivamente (controles negativos). Linha 2: $X$. fastidiosa transformada com pSG5 (900 pb). Linha 3: $X$. fastidiosa transformada com pSG15 (1.050 pb). Linha 6: $X$. fastidiosa transformada com pSG31 (700 pb). Linha 8: X. fastidiosa transformada com pSG52 (600 pb). Linha 10: X. fastidiosa transformada com pSG53 $(600 \mathrm{pb})$. Linha 12: X. fastidiosa transformada com pSG59 $(655 \mathrm{pb})$ 


\section{LISTA DE TABELAS}

Página

1 Genes de $X$. fastidiosa (ORFs) selecionados

2 Primers* preparados para amplificação de fragmentos de DNA das ORFs selecionadas

3 Primers utilizados para a confirmação da disrupção das ORFs de interesse.

4 Conjunto de primers utilizados para a confirmação da transformação de $X$. fastidiosa e os tamanhos de fragmentos esperados. 


\section{LISTA DE SIGLAS, ABREVIATURAS E SÍMBOLOS}

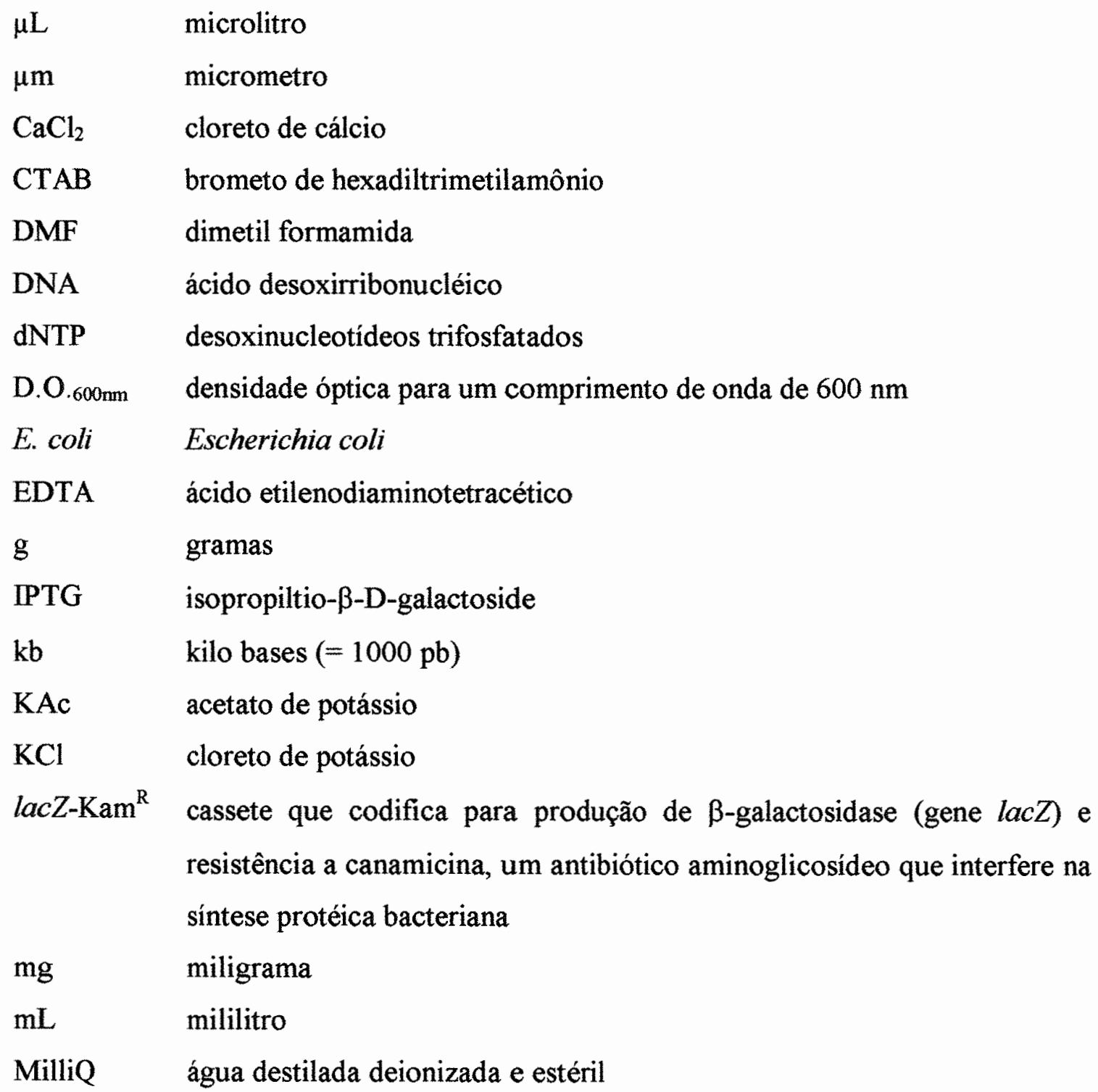




\begin{tabular}{|c|c|}
\hline $\mathrm{MnCl}$ & cloreto de manganês \\
\hline MOPS & ácido 3-[N-morfolino] propaneusulfonico \\
\hline $\mathrm{NaCl}$ & cloreto de sódio \\
\hline $\mathrm{NaOH}$ & hidróxido de sódio \\
\hline ng & nanograma \\
\hline ORF & quadro aberto de leitura (Open Reading Frame) \\
\hline $\mathrm{pb}$ & pares de bases \\
\hline PCR & reação em cadeia da polimerase (Polymerase Chain Reaction) \\
\hline Primer & oligonucleotídeo iniciador \\
\hline Primer (F) & primer "forward" que se anela no sentido da transcrição \\
\hline Primer (R) & primer "reverse" que é complementar à porção 3' do gene \\
\hline $\mathrm{rpm}$ & rotações por minuto \\
\hline $\mathrm{RbC}:$ & cloreto de rubídio \\
\hline SDS & $\begin{array}{l}\text { duodecil sulfato de sódio ou lauril sulfato de sódio (Sodium Duodecyl } \\
\text { Sulfate) }\end{array}$ \\
\hline Tris & Tris(hidroximetil)aminometano \\
\hline UV & ultra-violeta \\
\hline$v: v$ & volume:volume \\
\hline $\mathrm{xg}$ & múltiplos de força gravitacional terrestre (rcf) \\
\hline X-Gal & 5-bromo-4-cloro-3-indolil- $\beta$-D-galactoside \\
\hline YFP & proteína amarela fluorescente \\
\hline
\end{tabular}




\title{
DISRUPÇÃO DAS ORFS XF-810, XF-818, XF-1940, XF-2359 E XF-2708 DE Xylella fastidiosa-CVC POSSIVELMENTE RELACIONADAS À PATOGENICIDADE DA BACTÉRIA
}

\author{
Autora: SIMONE GUIDETTI GONZALEZ \\ Orientadora: Profa. Dra. HELAINE CARRER
}

\section{RESUMO}

Clorose variegada dos citros (CVC), também conhecida como amarelinho, é uma das doenças de citros mais severas da citricultura brasileira. A CVC é causada pela bactéria limitada ao xilema Xylella fastidiosa. Esta bactéria afeta principalmente as variedades de laranja doce e foi relatada pela primeira vez em 1987 nos estados de São Paulo e Minas Gerais. $O$ genoma de $X$. fastidiosa linhagem 9a5c foi completamente seqüenciado e revelou muitos genes provavelmente envolvidos na patogenicidade desta bactéria. Entre estes genes estão as endoglicanases, que são enzimas degradadoras de componentes da parede celular vegetal do hospedeiro e as adesinas, que são proteínas envolvidas na adesão das células bacterianas no xilema, como também auxiliam na formação de agregados bacterianos que causam a obstrução dos vasos do xilema, interferindo no transporte de água e sais minerais para todas as partes da planta, levando ao aparecimento dos sintomas relacionados a CVC. O objetivo deste trabalho foi a obtenção de mutantes de $X$. fastidiosa linhagem J1a12, pela disrupção das ORFs Xf-810, Xf-818 e Xf-2708, que apresentam função putativa de endoglicanases, da ORF Xf-2359 
possivelmente relacionada à uma pectate liase e da ORF Xf-1940, que apresenta similaridade de seqüência à metionina sulfoxido redutase, proteína identificada com a função de possuir adesão funcional na superfície da célula bacteriana. Neste trabalho, duas estratégias foram utilizadas para a construção dos vetores de disrupção das ORFs selecionadas no genoma de $X$. fastidosa: (1) substituição das ORFs pelo gene $y f p$, que codifica a proteína fluorescente amarela e, (2) inserção do cassete lacZ-Kam ${ }^{R}$ interrompendo a região codificadora das ORFs. Estes vetores foram usados para transformar $X$. fastidiosa linhagem J1a12 por eletroporação e confirmou-se a obtenção das bactérias mutantes por reações em cadeia da polimerase (PCR) com oligonucleotídeos específicos. 


\title{
DISRUPTION OF THE ORFS XF-810, XF-818, XF-1940, XF-2359 E XF-2708 OF Xylella fastidiosa-CVC PROBABLY RELATED TO PATHOGENICITY OF THE BACTERIA
}

\author{
Author: SIMONE GUIDETTI GONZALEZ \\ Adviser: Profa. Dra. HELAINE CARRER
}

\section{SUMMARY}

Variegated Clorose of the citros (CVC), also known as "amarelinho", is one of the more severe diseases of citrus of the Brazilian Citrus plantation. CVC is caused by Xylella fastidiosa, a limited bacteria to the xylem. This bacterium affects mainly sweet orange varieties and it was reported for the first time in 1987 in the states of São Paulo and Minas Gerais. The genoma of $X$. fastios $a$ strain $9 \mathrm{a} 5 \mathrm{c}$ was completely sequenced and it revealed many genes probably involved in the patogenicity of the bacteria. Among the genes, are the endoglucanases, that are degradative enzymes of the host cell wall components and the adesins, that are proteins involved in the adhesion of the bacterial cells in the xylem, as well as they aid in the formation of bacterial aggregation that cause the obstruction of the xylem vessels interfering in the transport of water and mineral salts for all the parts of the plant, providing the emergence of the symptoms related to CVC. The objective of this work was to produce mutants of $X$. fastidiosa strain J1a12, by disruption of the ORFs Xf-810, Xf-818 and Xf-2708, that present putative function of endoglucanases, Xf-2359 possibly related to a pectate liase and of Xf-1940, that presents 
sequence similarity to the methionine sulfoxide reductase, identified protein with the functional function of adhesion in the surface of the bacterial cell. In this work, two strategies were used for the construction of the disruption vectors of the selected ORFs in the X. fastidosa genome: (1) substitution of the ORFs for the $y f p$ gene, that codifies for the yellow fluorescent protein and, (2) insertion of the lacZ-Kam ${ }^{\mathrm{R}}$ cassette into the coding region of the ORFs. These vectors were used to transform $X$. fastidiosa strain J1a12 by electroporation and the mutants produced were confirmed by polymerase chain reactions (PCR) with specific oligonucleotids. 


\section{INTRODUÇÃo}

O Brasil é o maior produtor de frutas cítricas do mundo, dominando a maioria do mercado internacional, comercializando suco de laranja concentrado. Mais de $80 \%$ da produção do país concentra-se no estado de São Paulo, onde a indústria de citros e atividades associadas geram 3,4 milhões de empregos e mais de 1,5 bilhões de dólares por ano (Araújo et al., 2002). Acredita-se que, globalmente, um quinto do potencial rendimento de colheita é perdido por ano devido a doenças (Dow \& Daniels, 2000). E entre as muitas doenças que afetam esta cultura está a clorose variegada dos citros (CVC), a qual foi relatada pela primeira vez no Brasil em 1987 (Rossetti et al., 1990) e se disseminou para pelo menos $90 \%$ dos pomares do estado de São Paulo (Lambais et al., 2000).

A rápida disseminação da $\mathrm{CVC}$ entre os pomares brasileiros e o alto nível de dano causado por esta doença resultou em grandes perdas econômicas para os citricultures e para a indústria de suco de laranja (Della Coletta-Filho \& Machado, 2002).

A bactéria Xylella fastidiosa causadora da CVC foi o primeiro patógeno de plantas a ter o seu genoma completamente seqüenciado e esta escolha ocorreu devido a sua importância econômica e biológica (Simpson et al., 2000).

Uma caracteristica que parece ser importante na patogenicidade de $X$. fastidiosa é a presença de genes que codificam para enzimas como, celulases, pectato liase e proteases, que degradam a parede celular vegetal, e auxiliam a movimentação da bactéria através dos vasos do xilema durante a colonização do hospedeiro. Proteínas como adesinas, responsáveis pela adesão da bactéria ao xilema e no 
sistema digestivo dos insetos vetores parece também ser importante para patógenos como $X$. fastidiosa.

Muitos genes associados a fímbrias bacterianas, proteínas de adesão e exoenzimas conhecidas em outros patógenos bacterianos como relacionados a patogenicidade, foram identificados no genoma de $X$. fastidiosa (Simpson et al., 2000, Dow \& Daniels, 2000; Van Sluys et al., 2002), podendo ser alvos importantes para estudos de patogenicidade da bactéria.

Após identificação de supostas funções de genes por similaridade de seqüência com outros genes conhecidos em outros organismos, é necessário comprovar a função desses genes no organismo de interesse. Uma metodologia de estudo para elucidar a função dos supostos genes na patogenicidade de microorganismos é através de disrupção gênica por transformação genética. E utilizando os conhecimentos gerados sobre as complexas interações entre planta, patógeno e inseto vetor, espera-se contribuir com o desenvolvimento de tecnologias que permitam um controle mais efetivo da doença da CVC.

Sendo assim, os objetivos do presente trabalho foram: (a) o desenvolvimento de vetores para a disrupção das ORFs Xf-810, Xf-818, Xf-1940, Xf-2359 e Xf-2708 e (b) a transformação de $X$. fastidiosa por disrupção destas ORFs. 


\section{REVISÃO DE LITERATURA}

\subsection{Citros e CVC}

As plantas cítricas ocupam o primeiro lugar na produção mundial de frutas, desempenhando um papel de acentuada importância sócio-econômica mundial. Esta posição de destaque deve-se à grande aceitação dos citros na alimentação humana, na forma de fruta fresca e suco. O Brasil é um dos maiores produtores mundiais de laranja, e a estimativa da safra 2004 é de aproximadamente 17 milhões de toneladas em uma área plantada de aproximadamente 811 mil hectares (IBGE, 2004).

Entre os vários problemas que afetam a citricultura a ocorrência de doenças é o fator que mais contribue para baixar a produtividade. Entre elas, a Clorose Variegada dos Citros (CVC), causada pela bactéria Xylella fastidiosa, tem sido detectada nas várias regiões citrícolas do país, causando sérios prejuízos econômicos. Todas as cultivares comerciais de laranja doce são afetadas pela CVC, independente do porta-enxerto utilizado (Carvalho et al., 1995). Entretanto, plantas da cultivar pêra expressaram reações de resistência à colonização por $X$. fastidiosa, pelo acúmulo de cristais no lúmen dos vasos do xilema e pela deposição de substância semelhante a goma e de possivelmente compostos fenólicos nos espaços intercelulares das folhas (Alves, 2003).

Em 2003, 10,38 \% das plantas de laranja das variedades Pêra Rio, Valência, Natal e Hamlin do estado de São Paulo e parte do Triângulo Mineiro apresentaram sintomas de CVC de nível 1 (plantas com sintomas restritos às folhas) e $33,18 \%$ apresentaram sintomas de nível 2 (plantas com sintomas foliares e frutos miúdos; a 
distribuição desses frutos de tamanho reduzido pode ocorrer em uma área da planta assim como na planta toda), ou seja, pelo menos $43,56 \%$ das plantas estavam infectadas pela $X$. fastidiosa, sem considerar as plantas contaminadas que ainda não apresentaram sintomas (Fundecitrus, 2004).

Segundo dados da Fundecitrus (http://www.fundecitrus.com.br) observa-se a tendência no aumento da incidência da CVC ano a ano (de 1996 a 2003), o que revela a importância de se estudar o patógeno para se poder estabelecer estratégias eficientes de controle.

\subsection{Xylella fastidiosa}

Xylella fastidiosa é uma bactéria gram-negativa, sendo a única espécie do gênero e consiste de muitos patovares que causam doenças em culturas economicamente importantes como alfafa, amendoeira, uva, pêssego e ameixeira (Hopkins, 1989; Purcell \& Hopkins, 1996). Esta bactéria pode ser diferenciada em subespécies ou patovares dependendo de critérios como especificidade da planta hospedeira e patogenicidade (Hopkins, 1989; Chen et al., 1995; Pooler \& Hartung, 1995a; Banks et al., 1999).

Todas as estirpes da bactéria formam uma única espécie por tratar-se de um grupo de organismos com grande homologia genética (75 - 100\%) (Wells et al., 1987), especialmente na região $16 \mathrm{~S}$ do rDNA (Chen et al., 2000). E linhagens de $X$. fastidiosa isoladas de citros e café no Brasil podem incitar sintomas de doença, após inoculação mecânica, em sete variedades comerciais de videira (Vitis vinifera) crescendo no Brasil e Califórnia (Li et al., 2002).

As bactérias agrupadas nesta espécie possuem formato de bastonetes com cerca de $0,3-0,5 \times 1,0-3,5 \mu \mathrm{m}$, são atriquias, com parede celular enrugada formada por três camadas, aeróbicas estritas, gram-negativas limitadas ao xilema, fastidiosas e são adaptadas a concentrações diluídas de nutrientes (Chagas et al., 1992). 
A palavra fastidiosa é aplicada aos microorganismos que requerem meio de cultura complexo para o seu adequado crescimento in vitro e mesmo neste meio de cultura apresentam crescimento muito lento (Lemos et al., 2003).

$\mathrm{Na}$ década de 50 acreditava-se que a doença causada por $X$. fastidiosa em videira tinha natureza viral e utilizando plantas de alfafa e videira como plantas indicadoras foi demonstrado que mais de 100 espécies de plantas eram hospedeiras (Purcell \& Hopkins, 1996), e em 1973 dois trabalhos descreveram a associação da doença a organismos do tipo Rickettsia (Hopkins \& Mollenhaver, 1973; Goheen et al., 1973) mais tarde apropriadamente referidos como Bactérias Limitadas ao Xilema (XLB) (Chen et al., 1992). Somente em 1987 foi criado o gênero Xylella incluindo somente uma espécie, Xylella fastidiosa, como sendo uma bactéria relacionada ao gênero Xanthomonas spp. (Wells et al., 1987).

Xylella fastidiosa infecta uma ampla gama de plantas de diferentes grupos taxonômicos e causa doenças economicamente importantes, incluindo clorose variegada dos citros (CVC). Quando CVC foi descrita pela primeira vez (Rossetti et al., 1990) no Estado de São Paulo, ela já tinha se disseminado para as regiões de citricultura do Brasil e da Argentina (Brlansky et al., 1991).

Os postulados de Koch para a CVC foram primeiramente completados por Chang et al. (1993) e Hartung et al.(1994) e assim confirmou-se que a $X$. fastidiosa é o agente causal da CVC.

\subsubsection{Transmissão e vetores}

Em contraste com a maioria das bactérias fitopatogênicas, que tem o vento e a água como importantes agentes de disseminação, $X$. fastidiosa depende, exclusivamente, de insetos vetores para sua disseminação natural e penetração em tecido hospedeiro. Além da transmissão no campo de planta para planta através de cigarrinhas vetoras, 
pode ocorrer infecção também em viveiro não protegido e também durante a enxertia utilizando material vegetal contaminado (Carlos et al., 1997).

Os vetores de $X$. fastidiosa são cigarrinhas da família Cicadellidae, subfamília Cicadellinae e Cercopidae, que se alimentam da seiva bruta das plantas (Purcell \& Hopkins, 1996). Em plantas de citros, as espécies predominantes e comprovadamente transmissoras da bactéria são: Acrogonia terminalis, Oncometopia facialis, Dilobopterus costalimai, apesar de muitas outras espécies terem este potencial (Yamamoto, 2000).

As células bacterianas encontram-se na parte anterior do tubo digestivo das cigarrinhas (estomadéu), aderidas ao forro cuticular do pré-cibário, cibário e da porção anterior do esôfago, ou nas peças bucais (Purcell \& Hopkins, 1996). E estas células ganham acesso ao xilema quando o inseto se alimenta da seiva bruta (Lambais et al., 2000).

Não existe um período latente entre a aquisição e a inoculação pelo vetor. As cigarrinhas adultas, uma vez infectadas, podem transmitir $X$. fastidiosa, ao longo de suas vidas, devido à capacidade desta bactéria se multiplicar nos vetores (Hill \& Purcell, 1995). Ninfas também podem transmitir $X$. fastidiosa, mas perdem a capacidade de transmissão após as ecdises, quando ocorre mudança de ínstar ou passagem para o estádio adulto (Purcell, 1979). Suspeita-se que a aderência de $X$. fastidiosa ao estomadéu das cigarrinhas seja possivel devido à presença de fímbrias (filamentos extra celulares a célula bacteriana) e a ocorrência de uma matriz extracelular na qual as bactérias estão embebidas (Purcell \& Hopkins, 1996).

\subsubsection{Plantas hospedeiras}

Xylella fastidiosa apresenta uma ampla gama de hospedeiros que compreende pelo menos 30 famílias de plantas (Sherald \& Kostka, 1992). Além de CVC X. fastidiosa causa outras doenças de importância econômica como doença de Pierce na videira (Davis et al., 1978) que limita a produção comercial de cachos de uva (Vitis vinifera) na Flórida e nas regiões do sudeste dos Estados Unidos (Hopkins, 1989), nanismo do 
pessegueiro (Wells et al., 1983), nanismo da alfafa (Goheen et al., 1973), requeima da cafeeiro (Lima et al., 1998), requeima da ameixeira (Raju et al., 1982), requeima da pereira (Leu \& Su, 1993), requeima da amoreira (Kostka et al., 1986), requeima da maçã (Sherald et al., 1987), escaldadura da folha da cerejeira (Wells et al., 1980) e da amendoeira (Mircetich et al., 1976), entre outras.

Esta bactéria também apresenta hospedeiros alternativos. No Brasil, Leite et al. (1997), investigaram a presença de $X$. fastidiosa em plantas invasoras ocorrendo naturalmente em pomares de ameixeira, encontrando 11 espécies hospedeiras, muitas delas comuns em todo o território nacional como, capim-marmelada (Brachiaria plantaginea), capim-colchão (Digitaria sp.), capim-quicuio (Pennisetum clandestimum), capim-estrada (Paspalum urvillei), poaia branca (Richardia sp.) e assa-peixe (Vernonia sp.). Lopes et al. (1999) em São Paulo encontraram outros hospedeiros alternativos da bactéria, como: apaga-fogo (Alternanthera tenella), braquiária (Brachiaria decumbens), capim-carrapicho (Cenchrus echinatus), capim amargoso (Digitaria insularis), erva de Santa Luzia (Euphorbia hirta), erva-quente (Spermacoce latifolia), maria pretinha (Solanum americanum), picão (Bidens pilosa) e trapoeraba (Commelina benghalensis). Como pôde ser observado a gama de hospedeiros de Xylella fastidiosa é muito extensa e diversificada.

\subsubsection{Sintomas da CVC}

Clorose variegada dos citros (CVC) é uma doença causada pela bactéria gramnegativa Xylella fastidiosa (Chang et al., 1993; Hartung et al., 1994). O patógeno tem sido observado no xilema de plantas infectadas e em cigarrinhas vetoras (Brlansky et al., 1983).

Os sintomas de CVC são bastante evidentes nas folhas, ramos e frutos. A clorose foliar, um dos sintomas desta doença, se apresenta inicialmente nas regióes mediana e superior da copa, podendo ocorrer desfolha dos ramos ponteiros. Os sintomas foliares 
podem se restringir a alguns setores nas plantas afetadas ou evoluir, de modo disperso, atingindo toda a copa (Rossetti \& De Negri, 1990).

Nas folhas, surgem manchas cloróticas, de bordos irregulares e que contrastam com o verde do limbo, assemelhando-se a uma variegação (De Negri \& Garcia Junior, 1993). Mais de um tipo de clorose podem ser observados nas folhas maduras, como a clorose internerval brilhante típica de deficiência de zinco, afetando uniformemente todo o limbo foliar (Beretta et al., 1997) e a clorose variegada ou pontual de distribuição ao acaso no limbo foliar, com ou sem formação de tecido corticoso de aspecto ligeiramente saliente na face inferior, congruente às manchas cloróticas. As manchas pontuais podem coalescer formando áreas necrosadas estendendo-se até a borda do limbo foliar. Nas folhas também se observa redução da expansão foliar, afilamento e encurvamento para cima, e nos ramos ocorre encurtamento dos internódios (Machado et al., 1992).

Os sintomas nos frutos surgem após o aparecimento dos sintomas foliares e apenas em ramos afetados ocorrendo pegamento excessivo e anormal de frutos em ramos floríferos, formando pencas de frutos com acentuada redução de tamanho, amadurecimento precoce, consistência enrijecida e com suscetibilidade a queimaduras de sol (Lee et al, 1991)

Kostka et al. (1986) atribuíram a disfunção do xilema em doenças causadas por $X$. fastidiosa devido ao acumulo de polissacarídeos bacterianos, a produção de géis, gomas e tiloses pelo hospedeiro em resposta a infecção, e/ou acumulo de células bacterianas que fisicamente obstrui os vasos do xilema. Este bloqueio dos vasos pelas células bacterianas é associado com alterações fisiológicas, como a acumulação de toxinas (Hopkins, 1989), seqüestro de nutrientes importantes (Leite et al., 2002) e deficiência hormonal (Simpson et al, 2000) que são freqüentemente presentes na explicação da evolução da doença.

McElrone et al. (2001) confirmou que o estresse de água acentua a severidade dos sintomas em plantas de Parthenocissus quinquefolia infectadas com $X$. fastidiosa. Os resultados de análises físicas da interação entre estresse de água e a infecção de $X$. fastidiosa mostraram que esses fatores atuam conjuntamente em plantas de videira (McElrone et al., 2003). 
Alves (2003) observou que número de vasos do xilema colonizados por $X$. fastidiosa apresenta uma relação direta com o aparecimento de sintomas necróticos em folhas de ameixeira e cafeeiro, mas não com os sintomas em folhas de laranjeira caipira.

\subsubsection{Diagnóstico de $X$. fastidiosa}

O uso de métodos de diagnósticos para identificar a presença de $X$. fastidiosa em plantas é um passo importante na implementação de medidas de restrição da disseminação da doença no campo e em áreas não infectadas (Ferreira et al., 1999).

Tradicionalmente, $X$. fastidiosa tem sido isolada de tecidos sintomáticos e identificada pelo seu crescimento lento e pelas pequenas colônias opalescente em meios de cultura especialmente enriquecidos. Patovares podem ser identificados por testes de patogenicidade. Entretanto, testes de patogenicidade requerem tempo e trabalho intensivo (Hopkins, 1988). Muitas técnicas baseadas no DNA tem sido aplicadas para diferenciar patovares de Xylella (Albibi et al., 1998; Chen et al., 1992; Chen et al., 1995; Pooler \& Hartung, 1995a; Pooler \& Hartung, 1995b; Pooler et al., 1997) e "primers" específicos para PCR foram desenvolvidos para detectar raça de $X$. fastidiosa causadora da clorose variegada dos citros (Pooler \& Hartung, 1995b) e causadora da doença de Pierce (Banks et al., 1999).

\subsubsection{Controle da CVC}

A utilização de mudas livres do patógeno, o monitoramento da população de cigarrinhas com a aplicação de inseticidas e a poda de ramos doentes são as medidas principais empregadas para o controle da CVC (Donadio \& Moreira, 1997). E a Fundecitrus também recomenda a erradicação de plantas com menos de 2 anos que apresentam sintomas. 


\subsubsection{Algumas características do genoma da Xylella fastidiosa}

O genoma de $X$. fastidiosa, linhagem 9a5c, é composto por um cromossomo circular de $2.679 .305 \mathrm{pb}$, e dois plasmídeo o pXF51 e pXF1.3 com respectivamente $51.158 \mathrm{pb}$ e $1.285 \mathrm{pb}$, e apresenta $52,7 \%$ de G+C (Simpson et al., 2000).

Das 2.904 ORFs (quadro aberto de leitura - "open reading frames") 47\% apresentam similaridade de seqüência com proteínas conhecidas permitindo inferir funções putativas. Supostos genes de patogenicidade, virulência e adaptação foram atribuidos a 147 ORFs (Simpson et al., 2000). Com a caracterização de novos genes em outros organismos e o aperfeiçoamento dos programas de computador, Bhattacharyya et al. (2002) alisaram novamente o genoma de $X$. fastidiosa e observaram a existência de 2.985 ORFs, dos quais $58 \%$ apresentam função putativa.

O genoma da linhagem Temecula de $X$. fastidiosa isolada de videiras naturalmente infectadas e com sintomas de doença de Pierce (PD) também foi seqüenciado (Van Sluys et al. 2003) e apresenta um cromossomo circular com 2.519 .802 $\mathrm{pb}$ e apenas um pequeno plasmídeo de $1.345 \mathrm{pb}$, e das 2.066 ORFs $65,9 \%$ apresentam função putativa. Comparando-se com o genoma de $X$. fastidiosa causadora da CVC, 9a5c (Simpson et al., 2000) observou-se que $98 \%$ das ORFs presentes em Temecula também são encontradas na linhagem $9 \mathrm{a} 5 \mathrm{c}$, e a média de identidade de aminoácidos nas ORFs é de $95,7 \%$. X. fastidiosa PD apresenta 41 genes específicos, enquanto a 9a5c apresenta 152 genes específicos da linhagem. Os autores concluíram que estes dois organismos apresentam funções metabólicas idênticas e parece que usam um conjunto de genes em comum na colonização da planta e na patogenicidade, sendo assim o estudo de genoma funcional dos dois organismos poderia compartilhar mecanismos comuns para as duas linhagens, e a integração dos conhecimentos adquiridos individualmente poderia acelerar os avanços no combate a PD e CVC.

Ambas as linhagens de $X$. fastidiosa (PD e CVC) apresentam conjuntos de caminhos biossintéticos que permitem a síntese de todos os amonoácidos, purinas, pirimidinas, e nucleotídeos, e sistemas de transporte incluindo aqueles para carboidratos, 
íns, aminoácidos e peptídeos e também para a expulsão de drogas e toxinas (Simpson et al., 2000; Van Sluys et al. 2003). Entre os genes com funções determinadas por similaridade de seqüência que exibem alto nível de divergência entre as duas linhagens estão, por exemplo, os que podem estar envolvidos na interação $X$. fastidiosa-planta hospedeira, incluindo aqueles responsáveis pela adesão e agregação celular, resistência a drogas e enzimas de modificação e restrição de DNA (Van Sluys et al. 2003).

A presença de um gene precursor de poligalacturonase intacto na linhagem PD, que é um gene essencial para a síntese de enzimas de degradação da parede celular facilitando a migração entre os vasos, poderia ser responsável pela maior agressividade desta linhagem em relação à linhagem CVC (Almeida et al., 2001).

Analisado o genoma de algumas linhagens diferentes de $X$. fastidisoa, utilizando microarray, Nunes et al. (2003) observaram que a similaridade entre esses genomas é muito grande, apresentando mais de $90 \%$ de ORFs conservadas entre a linhagem 9a5c de citros e as linhagens que causam doença em ameixa, erva de Santiago, uva, amora, olmo e amendoeira. A conservação das ORFs aumenta para aproximadamente $97 \%$ quando a linhagem 9a5c é comparada com a linhagem de café e para aproximadamente $99 \%$ quando comparada com outros isolados de citros. Essencialmente, todos os genes envolvidos nos principais caminhos bioquímicos e funções celulares estão presentes em todas as linhagens de $X$. fastidiosa analisadas, sugerindo que a adaptação para viver no xilema de plantas é dependente de genes altamente conservados, responsáveis pelas principais características fisiológicas que envolvem um mecanismo para gerar energia utilizando carboidratos, incluindo enzimas para degradação de celulose (Nunes et al., 2003). E as diferenças na patogenicidade e gama de hospedeiros ocorrem devido às relativas pequenas diferenças genéticas entre os diferentes isolados de $X$. fastidiosa.

A análise da seqüência do genoma de $X$. fastidiosa revelou um grande número de genes cujas seqüências de aminoácidos apresentam alta similaridade com genes de Xanthomonas spp., particularmente Xanthomonas campestris pv. campestris (Xcc) (Simpson et al., 2000) e muitos desses genes estão envolvidos na patogenicidade ou virulência (Dow \& Daniels, 2000; Lambais et al., 2000). Esta similaridade na seqüência 
de aminoácidos entre Xanthomonas e $X$ fastidiosa não é surpreendente, já que estas duas espécies estão intimamente relacionadas (Wells et al., 1987). As diferenças entre os tamanhos dos genomas de $X$. fastidiosa $(\sim 2,7 \mathrm{Mb})$ e Xcc $(\sim 5,5 \mathrm{Mb})$, provavelmente refletem as diferenças nas estratégias para causar a infecção e na capacidade de crescimento dos dois organismos. Xylella fastidiosa depende de cigarrinhas para sua transmissão e é limitada ao xilema das plantas, enquanto Xcc pode infectar plantas intactas e é capaz de crescer e sobreviver na superficie de follhas de plantas e também no solo (Dow \& Daniels, 2000).

Quando $X$. fastidiosa é colocada para crescer em meio de cultura nutricionalmente rico, ela é incapaz de crescer mais rápido, e há evidências de que o pequeno tamanho relativo do genoma dessa bactéria, faltando capacidade metabólica de obter vantagens de nutrientes adicionais, faz com que ela seja adaptada para sobreviver em ambiente constante, mas nutricionalmente diluído (Van Sluys et al., 2002). Xanthomonas axonopodis pv. citri, Xanthomonas campestris pv. campestris, Ralstonia solanacearum e Agrobacterium tumefaciens apresentam genomas maiores do que $X$. fastidiosa, contendo genes para um extenso arsenal de caminhos metabólicos, e isso reflete na adaptação a diferentes condições ambientais. Além de colonizar o interior da planta hospedeira Xanthomonas é capaz de viver de forma epifeta, enquanto Ralstonia solanacearum e Agrobacterium tumefaciens vivem livremente no solo (Van Sluys et al., 2002).

Sistemas de secreção possuem importância fundamental para a correta translocação de proteínas e outras moléculas da bactéria patogênica para a célula hospedeira. Existem cinco diferentes formas de sistemas de secreção denominados como tipos I, II, III, IV e V (Lee \& Schneewind, 2001). O tipo I está envolvido na secreção de toxinas e o tipo IV está envolvido na exportação de macromoléculas, como proteínas de transferência conjugal, responsáveis pela mobilização de plasmídeo entre bactérias (Cao \& Saier, 2001; Van Sluys et al., 2002), e genes que codificam para estes dois sistemas de secreção estão presentes no genoma de $X$. fastidiosa (Simpson etal., 2000). Esta bactéria também apresenta genes que codificam para adesinas associadas a superficie, que são 
auto-transportadas pelo sistema de secreção do tipo V (Simpson et al., 2000; Van Sluys et al., 2002).

Muitas bactérias fitopatogências utilizam o sistema de secreção do tipo III (SSTIII) para causar doença em seus hospedeiros (He \& Jin, 2003). Proteínas bacterianas são liberadas dentro da célula do hospedeiro pelo SSTIII, onde funcionam como fatores de virulência modulando a maquinaria genética do hospedeiro suscetível para o seu próprio benefício (Chang et al., 2004). Muitos desses fatores de virulência podem atuar na supressão da resposta de defesa da planta e conseqüentemente promove a doença, enquanto outros podem atuar promovendo a liberação de nutrientes da célula vegetal (Dow \& Daniels, 2000). Plantas resistentes apresentam genes que codificam proteínas $\mathbf{R}$, que reconhecem proteínas bacterianas liberadas pelo SSTIII, resultando na indução de resposta de defesa da planta, incluindo a resposta de hipersensibilidade (RH), tornando o patógeno avirulento (Dangl \& Jones, 2001). As proteínas bacterianas identificadas por sua habilidade de engatilhar esta resposta de defesa da planta são considerados como determinantes de avirulência (Avr) (Dow \& Daniels, 2000; Chang et al., 2004).

Uma das diferenças entre $X$. fastidiosa e Xanthomonas spp. é a ausência na primeira do sistema de secreção do tipo III. E a análise do genoma de $X$. fastidiosa não identificou nenhum gene com seqüência de aminoácidos apresentando similaridade com produtos de genes de avirulência (genes avr) conhecidos (Simpson et al., 2000). A transmissão mediada por inseto, a restrição vascular e o lento crescimento da bactéria, podem ser conseqüências da falta da dependência da patogênese de $X$. fastidiosa com o sistema de secreção do tipo III (Dow \& Daniels, 2000).

As enzimas capazes de degradar a parede celular vegetal são secretadas pelo sistema de secreção do tipo II. Este sistema é requerido para a virulência de $X$. campestris pv. campestris e X. oryzae pv. oryzae (Dow et al., 1987; Ray et al., 2000). Em $X$. c. pv. campestris foram identificados um agrupamento de 11 genes denominados $x p s E F G H I J K L M N D$, que possuem função nesta secreção de proteínas e patogenicidade (Dums et al., 1991). A mesma organização gênica encontrada em X.c. pv. campestris 
ocorre em $X$. fastidiosa, e a maioria dos produtos dos genes possui alta similaridade na sequêencia de aminoácidos (Dow \& Daniels, 2000).

Em X. fastidiosa o sistema de secreção do tipo II está provavelmente envolvido na exportação de enzimas que degradam a parede celular, incluindo celulases e proteases. Possiveis funções para estas enzimas na patogênese da bactéria é na degradação da membrana de pontuação, permitindo a bactéria se mover para vasos não previamente colonizados e também na mobilização da parede celular para propósitos nutricionais ou para inibir a defesa da planta (Dow \& Daniels, 2000).

A produção de enzimas e polissacarídeos extracelulares por $X . c$. pv. campestris é estritamente regulada durante o crescimento em meio líquido e durante a doença. Foram identificados um grupo de genes que atuam na regulação da síntese desses fatores de virulência (Dow \& Daniels, 2000). Este grupo de genes, que é chamado de $r p f$ (fatores de regulação da patogenicidade) compreende nove genes (rpfA-I), sendo localizado dentro de uma região de $21,9 \mathrm{~kb}$ do cromossomo de $X$. c. pv. campestris (Barber et al., 1997; Tang et al., 1991; Dow et al., 2000). Enquanto em X. c. pv. campestris estes genes estão organizados em cluster, em $X$. fastidiosa genes com similaridade de seqüência aos rpf estão parcialmente localizados em cluster e não foram encontrados genes com similaridade a rpfD e rpfI (Dow \& Daniels, 2000).

O gene $r p f A$ codifica a principal aconitase de $X . c$. pv. campestris, a qual está envolvida na homeostase de ferro e também atua na regulação da expressão gênica de algumas enzimas extracelulares e de exopolissacarídeo (Wilson et al., 1998). Os genes $r p f B$ e rpfF estão envolvidos na regulação da síntese de moléculas sinal difusível de baixo peso molecular (DSF), a qual pode estar envolvida na comunicação entre as bactérias (Barber et al., 1997). RpfG, RpfH e RpfC podem estar envolvidos no sistema de transdução de sinal na percepção de sinais ambientais, e de DSF, na ativação da expressão de genes de patogenicidade e na regulação da síntese de DSF (Slater et al., 2000). 
A sinalização célula a célula mediada por DSF apresenta um importante papel na regulação de diversos processos fisiológicos, incluindo virulência para plantas e animais, nos distantes gêneros de bactérias (Kaiser \& Losick, 1993). Sinais de célula a célula permite a bactéria conduzir-se em um padrão de grupo, coordenando mudanças na expressão dos genes em resposta a mudanças ambientais e na população de células em crescimento, um fenômeno chamado de "quorum sensing" (Dow \& Daniels, 2000).

Xylella fastidiosa possui genes que apresentam alta similaridade a nove dos doze genes gum presentes em $X$. c. pv. campestris, que são responsáveis pela biossíntese de goma xantana. Sugerindo que a goma fastidiosa produzida por $X$. fastidiosa seja menos viscosa que a goma xantana produzido por $X$. c. pv. campestris (Simpson et al., 2000; Silva et al., 2001). Mudanças no último estádio da biossíntese da goma xantana levam a uma redução na virulência de $X$. c. pv. campestris (Katzen et al., 1998).

Embora o exato mecanismo de patogenicidade não seja conhecido, a adesão e a secreção de proteínas podem ser considerados elementos importantes. Uma importante característica de $X$. fastidiosa é a necessidade de se aderir na planta hospedeira e no inseto vetor. Para colonizar o inseto vetor, $X$. fastidiosa precisa se aderir no tecido do inseto e então resistir ao alto fluxo de seiva do xilema que o inseto suga. Na planta, a adesão na parede do xilema deve possibilitar condições apropriadas para o crescimento bacteriano e formação do biofilme (Smolka et al., 2003). Um importante aspecto da patogênese bacteriana é a agregação celular (interação bactéria-bactéria), que leva a obstrução vascular do xilema, causando estresse de água e nutrientes na planta (Purcell $\&$ Hopkins, 1996; Hopkins, 1989). Além disso, proteínas secretadas como proteases, celulases e lipases podem estar envolvidas no processo de infecção por degradarem o tecido da planta e permitindo, assim, a disseminação da bactéria através do sistema vascular (Hopkins, 1989). Proteínas tóxicas também podem ser secretadas e podem estar envolvidas no desenvolvimento da doença (Smolka et al., 2003). 


\subsection{A utilização de mutações para o estudo funcional de genes}

A relação entre fenótipos e os correspondentes genótipos é freqüentemente obtido por análises do fenótipo de mutantes e a subseqüente caracterização do gene. Alternativamente, uma análise genética reversa consiste na construção de mutações em genes específicos e a investigação do fenótipo nos mutantes gerados. Mutações aleatórias podem ser criadas por produtos químicos ou por mutagênese utilizando transposon, enquanto mutações específicas são normalmente geradas por recombinação homóloga no cromossomo de bactérias (Philippe et al., 2004).

O genoma de mais de 100 raças de bactérias está completamente seqüenciado. As ORFs (open reading frames) representam $90 \%$ do cromossomo bacteriano, mas a função de 40 a $60 \%$ dos genes não é conhecida (Philippe et al., 2004). A construção de mutantes é uma estratégia que pode ser utilizada para se decifrar a função desses genes.

Alguns métodos são utilizados para a obtenção de mutantes como: mutagênese por inserção-deleção, troca alélica e mutagênese utilizando transposon. Este último método não é utilizado para a disrupção de genes específicos, o que pode ser feito com a recombinação homóloga (mutagênese por inserção-deleção e troca alélica).

A troca alélica resulta na troca do gene selvagem por uma cópia interrompida por um marcador de seleção. Esta estratégia envolve a recombinação homóloga com duas permutas. A grande vantagem da troca alélica é o fato dessa estratégia gerar mutantes mais estáveis do que a mutagênese por inserção-deleção (Souza, 2002). Este método já foi utilizado em bactérias como Escherichia coli (Philippe et al., 2004), Mycobacterium tuberculosis (Malhotra et al., 2004) e Xylella fastidiosa (Gaurivaud et al., 2002). A disrupção gênica por troca alélica pode ser feita utilizando cassettes que confiram resistência a antibiótico e expressão da enzima $\beta$-galactosidase e também genes repórteres, como $y f p$ (proteína amarela fluorescente). A introdução de gene repórter no lugar do gene em estudo é muito interessante, pois assim torna-se possivel à monitoração da expressão do gene.

A mutagênese por inserção-deleção envolve a recombinação homóloga com uma permuta entre o gene selvagem no cromossomo bacteriano e uma cópia truncada desse 
gene, resultando na inserção do vetor plasmidial inteiro entre duas cópias do gene alvo que sofreu uma duplicação (Morrison et al., 1984). Este método de mutagênese tem sido usado para Streptococcus pneumoniae por mais de vinte anos (Lee et al., 1998) e também já foi utilizado em vários outros organismos como Neisseria gonorrhoeae (Hamilton et al., 2001), Mycobacterium smegmatis (Baulard et al., 1996) e Xylella fastidiosa (Monteiro et al., 2001b; Silva Neto et al., 2002; Gaurivaud et al., 2002).

Genes repórteres são amplamente utilizados para estudos de funções de genes. A proteína verde fluorescente (GFP) é codificada por um gene repórter, e é caracterizada pela habilidade de emitir fluorescência verde quando excitada por luz UV ou azul (Cody et al., 1993), sendo uma ferramenta poderosa para análises na célula através da emissão de fluorescência de suas proteínas, permitindo análises em tempo real de eventos moleculares que ocorrem na célula (Kain, 1999).

A GFP é uma proteína pequena encontrada na água viva Aequorea Victoria, é um excelente marcador para estudos de interações entre planta e patógeno (Xi et al., 1999), já que para a análise no microscópio de fluorescência é necessário apenas preparações simples e a integridade da estrutura da planta e da bactéria permanecem bem preservadas (Ramos et al., 2002).

Existem os variantes de GFP que apresentam as propriedades espectrais alteradas nos comprimentos de onda de excitação e emissão máximas, apresentando um aumento na intensidade da cor da fluorescência, por exemplo, azul (EBFP) (Kain, 1999), verde (EGFP) e amarelo (EYFP) (Stuurman et al., 2000). Uma característica dos variantes de $g f p$ é a habilidade de emitirem também fluorescência verde (Kain, 1999).

A expressão do gene $y f p$ tem sido utilizada para estudos com microorganismos(Griesbeck et al., 2001, Miller et al., 2000, Stuurman et al. 2000), células de plantas (Nowak et al., 2004, Tse et al., 2004, Bolte et al., 2004), de animais (Narayan \& Greif, 2004), e em células de humanos (Kretzschmar et al., 2004, Sorkina et al., 2003). 


\subsection{Transformação da bactéria Xylella fastidiosa e obtenção de mutantes}

Muitos genes supostamente relacionados com a patogenicidade estão presentes no genoma de $X$. fastidiosa, mas pouco se sabe experimentalmente sobre os mecanismos de patogenicidade comparados com outras bactérias gram-negativas. Para o estudo desses genes é necessária a utilização de métodos de disrupção, para se poder inferir a importância desses genes na interação planta-patógeno.

Em 2001 iniciou-se o desenvolvimento da tecnologia de transformação dessa bactéria através da publicação de três trabalhos desenvolvidos separadamente (Guilhabert et al., 2001; Monteiro et al., 2001b; Qin \& Hartung 2001).

Transformação de $X$. fastidiosa relatado por Qin \& Hartung (2001) mostrou ser instável, assim o plasmídeo vetor utilizado pode ser útil para a complementação de estudos in vitro de mutantes de $X$. fastidiosa, mas não em estudos in planta.

O primeiro relato de transformação estável de $X$. fastidiosa foi feita por Monteiro et al. (2001b) através do desenvolvimento de vetores contendo uma parte da origem de replicação da bactéria (OriC) de 366 pb (que compreende a região intergência entre os genes $d n a A$ e $d n a N$ ) ou a OriC inteira de aproximadamente $1,9 \mathrm{~kb}$ (contendo gene $d n a A$ e as regiões que o flanqueiam) e o gene que confere resistência a canamicina sob a ação do promotor do gene que codifica o RNA ribossômico $16 \mathrm{~S}$, também de $X$. fastidiosa. Os autores testaram a transformação em cinco isolados de $X$. fastidiosa causadora de CVC e dois isolados de café, mas somente conseguiram sucesso na transformação de apenas dois isolados de CVC (J1a12 e B111) e após alguns repiques ocorreu a integração dos plasmídeos vetores na região promotora do gene do RNA ribossômico $16 \mathrm{~S}$ por recombinação homóloga. Os autores mostraram que a mutação de um gene específico é possível nessa bactéria.

Guilhabert et al. (2001) obtiveram $X$. fastidiosa de uva transformada através de transposição utilizando transpossomos. O transpossomo é a associação de uma transposase hiperativa com um fragmento de DNA linear contendo as seqüências de 
reconhecimento da enzima transposase e um gene marcador. Após seqüenciamento de dez mutantes os autores observaram que em dois deles a inserção do gene de resistência ao antibiótico canamicina ocorreu em regiões intergênicas e em oito ocorreram em ORFs conhecidas ou hipotéticas. Assim os autores obtiveram mutantes resistentes a canamicina e os transpossomos se mostraram eficientes para a transformação de $X$. fastidiosa.

Os primeiros relatos de disrupção gênica em $X$. fastidiosa-CVC foram publicados por Silva Neto et al. (2002) e Gaurivaud et al. (2002). Silva Neto et al. (2002) construíram um vetor de transformação de $X$. fastidiosa ligando o plasmídeo nativo de $X$. fastidiosa pXF1.3 no plasmídeo comercial pBluescript, e adicionando também o gene que confere resistência a canamicina sob a ação do promotor do gene do RNA ribossômico 16S. Como o pXF1.3 apresenta uma ORF com alta similaridade com uma proteína de replicação de Actinobacillus, foi possível a obtenção de mutantes após a clonagem de parte do gene xps $D$. Os autores obtiveram uma porcentagem de $10 \%$ de mutantes apresentado o gene $x p s D$ interrompido devido a integração de todo o plasmídeo no meio do gene, por recombinação homóloga com uma permuta. Os autores escolheram esse gene para a disrupção devido ao fato de que a proteína codificada por ele faz parte do sistema de secreção do tipo II e em fitopatógenos proteínas secretadas através deste sistema são principalmente enzimas hidrolíticas, que apresentam um importante papel na patogênese de microorgasnismos.

Já Gaurivaud et al. (2002) utilizaram a origem de replicação cromossômica de $X$. fastidiosa nos vetores construídos para a disrupção por inserção-deleção dos genes bga e $c v a B$, e um pedaço desses genes. O gene bga codifica a enzima $\beta$-galactosidase que apresenta fenótipo de fácil visualização (coloração azul da colônia) foi utilizado como um modelo para a disrupção e o gene $c v a B$ apresenta homologia com um componente do sistema $\mathrm{ABC}$ de transporte de colicina $\mathrm{V}$, possivelmente envolvido na patogenicidade dessa bactéria (Simpson et al., 2000). Os autores também obtiveram a disrupção do gene bga através de troca alélica, interrompendo o gene por inserção do gene que confere resistência ao antibiótico canamicina. 
A adesão de Xylella fastidiosa ao vaso de xilema e ao inseto vetor pode ser requerida para a virulência e transmissão da bactéria, com esta observação Feil et al (2003) fizeram a disrupção dos genes fim $A$ e fim $F$ que codificam a principal proteína que apresenta fímbria FimA e homólogo da fímbria adesina MrkD, para determinar suas funções no processo de adesão. Fímbrias são filamentos que se estendem da superfície bacteriana (Soto \& Hultgren, 1999) e podem servir como uma âncora ao substrato e também na agregação entre as células. Estes autores obtiveram mutantes de linhagem de $X$. fastidiosa que causa doença em videira, através de troca alélica, utilizando o plasmídeo pUC18 com a sua origem de replicação e fizeram a disrupção dos genes pela inserção do gene de resistência ao antibiótico canamicina. Foi observado, com o auxilio de microscópio eletrônico, que o tamanho e número das fímbrias, agregação celular e número de células diminuíram para os mutantes FimA $^{-}$e FimF-, estes mutantes permaneceram patogênicos a videira, porém apresentaram uma população de células reduzida quando comparada com os tipos selvagens.

Guilhabert \& Kirkpatrick (2003) construíram vetor para transformação de $X$. fastidiosa causadora de doença em videira, que se replica de forma autônoma na bactéria, se mantendo estável geneticamente, mas após inoculação das linhagens transformadas em plantas de videira, a bactéria perde o plasmídeo. Assim este vetor só poderia ser utilizado para estudos in vitro.

Koide et al. (2004) obtiveram $X$. fastidiosa-CVC resistentes a canamicina utilizando mutagênese através de transposons. Este sistema permitiu inserções aleatórias e a geração de um grande número de mutantes de uma só vez. Os autores obtiveram mutantes apresentando a disrupção de diferentes genes e mostraram que este sistema de transformação não tem preferência por inserção em seqüências específicas.

Através de disrupção do gene $r p f F$ de $X$. fastidiosa que causa doença em uva, Newman et al. (2004) observaram que este gene é importante na comunicação entre as células devido a produção de uma molécula sinal difusível de baixo peso molecular (DSF). Os mutantes apresentaram baixa transmissão pelas cigarrinhas vetoras, e as cigarrinhas que se alimentaram de plantas infectadas com os mutantes eram capazes de 
se "limparem" dos mutantes, isso se deve ao fato desses mutantes não formarem o biofilme para se fixarem no interior do inseto, pois DSF regula a produção de exopolissacarídeos para a formação do biofilme. Os autores observaram que na planta a formação do biofilme não é afetada nos mutantes, esta diferença pode ser devido ao tipo de ambiente a ser colonizado pela bactéria no inseto e na planta e tal diferença na arquitetura do biofilme está sob o controle da bactéria e do ambiente.

Transformação genética de Xylella fastidiosa pode permitir a análise das funções dos genes com a geração de mutantes defectivos em diversos processos, permitindo assim um melhor entendimento dos mecanismos moleculares da patogenicidade de $X$. fastidiosa e, talvez, possibilitando o surgimento de tratamentos eficientes para o controle de doenças causadas por esta bactéria.

\subsection{Hospedeiros alternativos para o estudo da patogênese de Xylella fastidiosa}

Uma das dificuldades para o estudo de potenciais genes de patogenicidade de $X$. fastidiosa em plantas de citros, que apesar de ideal é inapropriada, está no fato de que o desenvolvimento dos sintomas em plantas inoculadas ocorre somente após seis meses a um ano (Hartung et al., 1994). Para solucionar este problema é necessária a utilização de hospedeiros alternativos que apresentem resposta rápida para os testes de patogenicidade.

Inoculando $X$. fastidiosa em plantas de tabaco (Nicotiana tabacum cultivar RP1) Lopes et al. (2000) observaram os primeiros sintomas em poucas plantas depois de seis semanas após a segunda inoculação, e em todas as plantas após oito semanas. Os sintomas se caracterizaram por lesões pequenas de cor laranja-escuro, que apareceram inicialmente na margem de folhas mais velhas. Já Alves et al. (2003) estudando três diferentes cultivares de Nicotiana tabacum (TNN, Havana e RP1) observaram que os sintomas foliares nas cultivares RP1 e Havana eram similares aos descritos por Lopes et al. (2000) e o sintoma na cultivar TNN se caracterizava principalmente pela clorose 
internerval. Mas os sintomas em Havana eram mais pronunciados e as folhas com sintomas permaneciam na planta por um período de tempo maior do que nas outras duas cultivares, demonstrando assim que a cultivar Havana é mais apropriada para ser um hospedeiro experimental de $X$. fastidiosa do que as outras duas cultivares estudas.

Plantas de vinca (Catharanthus roseus) também podem ser hospedeiras sintomáticas da linhagem de $X$. fastidiosa causadora da CVC, como demonstrado por Monteiro et al. (2001a). Estes autores observaram os primeiros sintomas nas plantas inoculadas com a bactéria após dois meses, e após quatro meses todas as plantas inoculadas apresentaram sintomas. Os sintomas observados inicialmente foram deformação das folhas jovens e redução no porte das plantas, ocorreu também o aparecimento de manchas cloróticas marginais e ao longo das nervuras das folhas mais velhas, estas folhas sofriam abscisão mais cedo e em casos extremos as plantas retinham apenas as folhas apicais. Os autores também confirmaram que Xylella fastidiosa reduz sua virulência com o cultivo continuado em laboratório, mas não perde a patogenicidade devido aos repiques, pois os sintomas se manifestaram primeiro em maior porcentagem nas plantas inoculadas com a bactéria que foi menos repicada.

\subsection{Parede celular vegetal}

Nas paredes celulares vegetais estão presentes a parede celular primária, a lamela média e pode estar presente a parede celular secundária. A lamela média compreende os espaços entre as paredes primárias e as células adjacentes, sendo constituída principalmente de pectina, pectato e hemicelulose. A parede secundária, que pode ou não estar presente, fornece um suporte estrutural à célula, apresentando também lignina (Prade et al., 1999). As paredes primárias, de um modo geral, não são uniformes na espessura e áreas mais finas, denominadas de campos primários de pontuação, estão presentes (Raven et al., 2001). Nas células condutoras e de sustentação a parede secundária estabelece-se somente sobre uma parte da parede primária não cobrindo 
também os campos primários da parede primária, do que decorrem essas características pontuações (Raven et al., 2001).

Polissacarídeos da parede celular vegetal são os mais abundantes compostos orgânicos encontrados na natureza. Eles representam $90 \%$ da parede celular vegetal e podem ser divididos em três grupos: celulose, hemicelulose e pectina (McNeill et al., 1984).

Celulose consiste de cadeias lineares de $\beta$ - D-glicopiranosil ligadas por pontes glicosídicas $\beta-1 \rightarrow 4$, que são condensadas por pontes de hidrogênio na estrutura cristalina, chamada de microfibrilas (Kolpak \& Blackwell, 1976). Estas microfibrilas consistem de cadeias com mais de 250 glicoses e são ligadas pelas hemiceluloses (Carpita \& Gibeaut, 1993). Em adição a estrutura cristalina, a celulose contém regiões não cristalinas dentro das microfibrilas (regiões amorfas) (Vries \& Visser, 2001).

Hemiceluloses são polissacarídeos mais heterogênios e depois da celulose são os polissacarídeos mais abundantes na parede celular vegetal. Pectina forma outro grupo de heteropolissacarídeos e consiste de cadeia linear de unidades de ácido D-galacturônico (Vries \& Visser, 2001).

Hemicelulose e polissacarídeos de pectina, e também lignina, interagem com as fibras de celulose, criando uma estrutura rígida fortalecendo a parede celular vegetal (Vries \& Visser, 2001).

\subsection{Fatores relacionados a patogenicidade enzimas degradadoras da parede celular vegetal}

Os principais grupos de substâncias secretadas por bactérias, que parecem estar envolvidas no desenvolvimento de doenças, tanto direta como indiretamente, são enzimas, toxinas, reguladores de crescimento e polissacarídeos (Long \& Staskawics, 1993). Foi demonstrado em alguns patógenos a produção de compostos que atuam como supressores da resposta de defesa das plantas hospedeiras e enquanto outros que 
produzem substâncias que fazem com que a bactéria se adere a planta para assim crescer e colonizá-la (Leite et al., 2001).

Observações de cortes longitudinais de pecíolos de folhas de videira com doença de Pierce, revelaram nos elementos traqueais do xilema a presença de $X$. fastidiosa formando agregados bacterianos (Tyson et al., 1985), que podem funcionar como uma rede atraindo nutrientes para a colônia, causando deficiências nutricionais em plantas afetadas (Leite et al., 2002). Os agregados bacterianos, juntamente com goma do hospedeiro, obstruem os vasos do xilema resultando em estresse de água (Beretta et al., 1997).

Análises através de microscopia de tecidos vasculares de diferentes plantas colonizadas por $X$. fastidiosa mostram que o movimento da bactéria de célula para célula é restrito às membranas do xilema. O movimento da bactéria de um vaso para outro vaso do xilema sugere a produção de enzimas que degradam a membrana e a parede celular vegetal (Hill \& Purcell, 1995, Alves, 2003). Os sintomas parecem estar dependentes com a taxa e extensão da colonização (Hill \& Purcell, 1995).

Muitos fitopatógenos são capazes de produzir enzimas degradadoras da parede celular vegetal como celulases, xilanases, pectinases e proteases, que podem ser importantes fatores de patogenicidade (Norman-Setterblad et al., 2000). Genes que codificam precursor de poligalacturonase, celulases e muitas proteases, como também a completa maquinaria necessária para a secreção das enzimas degradadoras da parede celular vegetal, foram identificados no genoma de Xylella fastidiosa (Simpson et al., 2000).

Em $X$. fastidiosa, enzimas secretadas que degradam a parede celular vegetal podem desempenhar um papel importante na migração entre os vasos, através da degradação da parede celular primária das pontuações dos vasos do xilema (Alves, 2003). Alternativamente, a degradação localizada da parede celular vegetal pode liberar carboidratos necessários para o crescimento bacteriano no xilema (Lambais et al., 2000). 


\subsubsection{Celulases}

As celulases apresentam importante papel na patogenicidade de muitos microorganismos fitopatogênicos, auxiliando na dispersão dos mesmos no interior da planta e assim, favorecendo a colonização. Estas enzimas também podem ser utilizadas para explorar a energia e o carbono disponível na celulose, por organismos como fungos e bactérias que produzem uma mistura de celulases que atuam em conjunto (Teeri, 1997).

Quatro classes de enzimas estão envolvidas na biodegradação da celulose. Endoglicanases (EC 3.2.1.4) catalisam a hidrólise interna de ligações B-1,4-Dglicosídicas da celulose. Celobiohidrolase (EC 3.2.1.91) libera celobiose a partir de celulose cristalina. $\beta$-Glicosidases (EC 3.2.1.21) degrada oligossacarídeo a glicose. Exoglicanases libera glicose a partir das extremidades da cadeia de celulose (Vries \& Visser, 2001).

A patogenicidade do patógeno de milho Cochliobolus carbonum mutante para a celulase CEL1 não foi alterada, comparando-se com o tipo selvagem, indicando que esta enzima, por si só, não é um determinante para a doença (Sposato et al., 1995). Para Erwinia chrysanthemi as celulases celZ e celY não são essenciais para o desenvolvimentos dos sintomas em folhas de Saintpaulia ionantha, embora com os mutantes celY os sintomas demorem mais para aparecerem (Boccara et al., 1994).

Já em Erwinia carotovora subsp. carotovora nos mutantes para celulase CelV1 ocorreu redução na virulência, sugerindo que este gene possa aumentar a habilidade da bactéria em macerar o tecido (Mae et al., 1995).

Em Clavibacter michiganensis subsp. michiganensis a transformação do mutante celA $A^{-}$com este gene restabeleceu a atividade desta celulase (endoglicanase) e o fenótipo patogênico, sugerindo que esta endoglicanase desempenha um importante papel na patogenicidade deste microorganismo (Jahr et al., 2000).

Muller et al. (1997) observaram que a celulase CEL1 de Claviceps purpurea é induzida durante os primeiros dias da infecção de centeio. Esta enzima pode estar 
envolvida na penetração e degradação da parede celular do hospedeiro, desempenhando papel no processo de infecção.

Com o seqüenciamento do genoma de Xylella fastidiosa foram identificados genes apresentando homologia com endoglicanases de Xanthomonas campestris pv. campestris (ORFs Xf-810 e Xf-818) e de Ralstonia solanacearum (ORF Xf-2708) (Wulff, 2002), que possivelmente atuam na patogenicidade da bactéria.

\subsubsection{Pectato liase}

Pectinas são heteropolissacarídeos complexos que contem duas diferentes regiões definidas (Perez et al., 2000). A região "lisa" consiste de esqueleto de ácido Dgalacturônico e a região que apresenta ramificações com diferentes açúcares (Vries \& Visser, 2001).

A diferença estrutural entre a principal cadeia das regiões ramificadas e não ramificadas da pectina tem implicações nas enzimas envolvidas na degradação destas regiões. $O$ esqueleto da região não ramificada pode ser hidrolisado por pectina liases (EC 4.2.2.10), pectato liases (EC 4.2.2.2) e poligalacturonases (EC 3.2.1.15 e EC 3.2.1.67) (Vries \& Visser, 2001).

Pectina liase prefere substratos com alto grau de metil-esterificação, enquanto que pectato liases preferem substratos com baixo grau de esterificação. Uma diferença entre estes dois tipos de enzimas é a necessidade de íons $\mathrm{Ca}^{2+}$ para a catálise por pectato liase e o não requerimento pela pectina liase. Seis genes de pectina liase foram identificados no genoma de Aspergillus niger e apenas uma pectato liase (Vries \& Visser, 2001).

Pectinases são conhecidas por causarem maceração do tecido, como no caso da maioria de Erwinia spp. (Hendawy et al., 1997). Entre as enzimas que degradam a pectina a pectato liase é a principal delas e apresenta papel importante no desenvolvimento de doenças de podridão mole da raiz. Em Erwinia chrysanthemi, nove pectato liases extracelulares foram identificadas (Bekri et al., 1999). Enquanto em todas 
as linhagens de Pseudomonas viridiflava estudadas por Liao (1989) uma única enzima péctica é necessária para a maceração do tecido vegetal, sendo esta uma pectato liase.

Nectria hematococca, um fungo patógeno de ervilha, apresenta dois genes que codificam para pectato liases pelA e pelD, sendo pelA induzido por pectina enquanto pelD é induzido somente in planta. A disrupção tanto de pelA ou pelD sozinhos não acarreta na diminuição da virulência, mas a disrupção de ambos os genes causa uma redução drástica na virulência do patógeno, demonstrando que pectato liase é um fator de virulência para este fungo (Rogers et al., 2000).

Um gene com grau de similaridade de $1 \mathrm{e}^{-10} \mathrm{com}$ pectato liase de Pseudomonas viridiflava (Liao et al., 1988) foi verificado no genoma de $X$. fastidiosa, mas os 236 aminoácidos da proteína de $X$. fastidiosa é similar somente a porção $\mathrm{C}$ terminal da proteína de 896 aminoácidos de $P$. viridiflava.

\subsection{Adesão celular e MsrA}

O contato célula a célula é um processo essencial para o estabelecimento da interação planta-patógeno e desenvolvimento da doença. Durante o processo de infeç̧ão e desenvolvimento da CVC, $X$. fastidiosa interage com o seu inseto vetor e células da planta hospedeira, e também com outras células da bactéria em microcolônias. Polissacarídeos extracelulares e adesinas que apresentam ou não fimbrias, desempenham papéis importantes como mediadores desse contato célula a célula de $X$. fastidiosa (Lambais et al., 2000).

Fímbrias do Tipo IV são estruturas polares filamentosas observadas em muitos patógenos bacterianos (Fernandez \& Berenguer, 2000). Genes codificando proteínas responsáveis pela biogênese das fímbrias do tipo IV foram identificadas no genoma da $X$. fastidiosa (Simpson et al., 2000). Estas fímbrias podem ser necessárias para a ligação polar de $X$. fastidiosa à parede do intestino do inseto vetor, contribuindo para a colonização do vetor e sobrevivências das células bacterianas, e também na aderência de $X$. fastidiosa à parede celular do xilema, bem como para a formação de microcolônias 
nos vasos do xilema e/ou movimentação da bactéria no sistema vascular da planta (Lambais et al., 2000).

Além de exoplissacarídeos e fímbrias do tipo IV foram identificados três genes no genoma de $X$. fastidiosa que codificam supostas adesinas, homólogos a adesinas de Haemophilus influenzae e Moraxella catharrhalis (Simpson et al., 2000). Em patógenos de animais e humanos adesinas estão envolvidas na aderência ao tecido epitelial (Kerr, 1999). Em fitopatógenos, adesinas são importantes na aderência ao tecido do vetor e do hospedeiro.

Uma das adesinas encontradas no genoma de $X$. fastidiosa é a enzima denominada metionina sulfoxido redutase (MsrA; EC 1.8.4.6) que é uma enzima de manutenção da adesão, que auxilia na preservação da aderência de alguns patógenos bacterianos de humanos (Leite et al., 2002).

Leite et al. (2002) utilizando microanálise de raio $X$ demonstraram a presença de enxofre elementar em células de $X$. fastidiosa crescendo in vitro e em células encontradas dentro de vasos do xilema. Picos de cálcio e magnésio foram detectados em associação com enxofre em vasos obstruídos. Os autores propuseram que radicais tióis (SH), mantidos pela enzima MsrA, podem ser ativados na superfície da bactéria e parece promover a agregação célula a célula, através da ligação dissulfeto com grupos tióis da superficie de células adjacentes ou por ligação de grupos de enxofre através de íons divalentes (S-Ca-S, S-Mg-S). Ocorreriam interações entre as células de $X$. fastidiosa e os vasos do xilema nas porções hidrofóbicas de ambos os lados e adicionalmente ocorreriam interações entre o enxofre da superficie de $X$. fastidiosa e cargas localizadas no xilema diretamente ou por pontes através de cálcio e magnésio. Após adesão inicial, a bactéria iniciaria a produção de goma fastidiosa, que estaria envolvida na arquitetura do biofilme formado pela $X$. fastidiosa no interior dos vasos do xilema, causando a obstrução.

A falta de capacidade de produzir MsrA de raças de Streptococcus pneumoniae, Neisseria gonorrhoeae e Escherichia coli acarretou na redução da habilidade de adesão quando comparado com suas respectivas raças selvagens (Wizemann et al., 1996). Dhandayuthapani et al. (2001) através de disrupção do gene $m s r A$, também observaram 
redução da aderência do patógeno de humano Mycoplasma genitalium a eritrócitos de carneiro e redução da virulência.

Uma característica importante de MsrA é que ela é também uma enzima de reparo antioxidante, catalisando a redução de resíduos de metionina sulfoxido de proteinas em metionina (Dhandayuthapani et al., 2001).

Oxigênio reativo pode causar dano a muitos componentes celulares e é correlacionado com muitas doenças. As células desenvolveram uma variedade de mecanismos que destroem estas moléculas reativas ou reparam o dano quando ele ocorre. Em proteína um dos aminoácidos mais facilmente oxidado é a metionina, que é convertida a metionina sulfoxido. Sendo a enzima MsrA um importante antioxidante, e há evidências que esta enzima desempenha papel importante na proteção das células contra danos oxidativos (Weissbach et al., 2002).

Hassouni et al. (1999) observaram que o patógeno de planta Erwinia chrysanthemi mutante para MsrA eram mais sensiveis ao estresse oxidativo, eram menos móveis em superficie sólida, os mutantes apresentaram a virulência reduzida em folhas de chicória e nenhuma invasão sistêmica foi observada quando estes mutantes eram inoculados em plantas de Saintpaulia ionantha. Sugerindo que as plantas respondem a patógenos virulentos produzindo espécies ativas de oxigênio, e a enzima MsrA, reparando danos oxidativos, permite a sobrevivência do patógeno no ambiente interno do hospedeiro, suportando a teoria de que espécies ativas de oxigênio desempenham um papel importante na defesa da planta (Hassouni et al., 1999). 


\section{MATERIAL E MÉTODOS}

\subsection{ORFs de Xylella fastidiosa selecionadas}

$O$ banco de dados de Xylella fastidiosa, isolado 9a5c, (http://watson.fapesp.br/onsa/genoma3.htm) (Simpson et al., 2000) foi utilizado para a obtenção da seqüência das ORFs (Open Reading Frames - Quadro aberto de leitura) deste trabalho.

Foram selecionadas as ORFs $\mathrm{Xf}-810, \mathrm{Xf}-818$ e $\mathrm{Xf}-2708$ que apresentam atividade celulásica comprovada, mais especificamente de endoglicanases (Wulff, 2002), a ORF Xf-1940 que apresenta similaridade com genes que são essenciais para a produção e manutenção de adesinas funcionais na superficie da célula e a ORF Xf-2359, que foi classificada como uma proteína hipotética no genoma de $X$. fastidiosa, mas que apresenta similaridade $\left(1 \mathrm{e}^{-10}\right)$ com pectato liase de Pseudomonas viridiflava (Liao et al., 1988).

$\mathrm{Na}$ Tabela 1 estão listadas as ORFs alvo selecionadas, o nome do cosmídeo usado para amplificar a sequencia de nucleotídeos de cada ORF, a função putativa, o número de pares de bases $(\mathrm{pb})$ e o valor de similaridade destas ORFs com relação a proteínas de outros organismos. 
Tabela 1. Genes de X. fastidiosa (ORFs) selecionados

\begin{tabular}{|c|c|c|c|c|}
\hline $\begin{array}{l}\text { ORFs e coordenada } \\
\text { cromossomal }^{1}\end{array}$ & Cosmídeo & Função putativa & $\begin{array}{c}\text { Tamanho } \\
(\mathrm{pb})\end{array}$ & e-value ${ }^{2}$ \\
\hline $\begin{array}{c}\text { Xf }-810 \\
(761713-763410 U)\end{array}$ & XF-07H04 & endoglicanase & 1698 & $3 \mathrm{e}^{-50}$ \\
\hline $\begin{array}{c}\text { Xf }-818 \\
(769640-771418 \mathrm{C})\end{array}$ & $\mathrm{XF}-07 \mathrm{H} 04$ & endoglicanase & 1779 & $1 e^{-145}$ \\
\hline $\begin{array}{c}\mathrm{XF}-1940 \\
(1842787-1843437 \mathrm{C})\end{array}$ & $\mathrm{XF}-03 \mathrm{H} 12$ & adesina & 651 & $2 e^{-67}$ \\
\hline $\begin{array}{c}\text { Xf }-2708 \\
(2588067-2589137 U)\end{array}$ & $\mathrm{XF}-07 \mathrm{~B} 07$ & endoglicanase & 1071 & $2 e^{-85}$ \\
\hline $\begin{array}{c}\text { Xf-2359 } \\
(2.235 .666-2.234 .956 \mathrm{C})\end{array}$ & $\mathrm{XF}-07 \mathrm{~A} 02$ & pectato liase & 711 & $1 e^{-10}$ \\
\hline
\end{tabular}

${ }^{1}$ A coordenada cromossomal refere-se a posição do gene no genoma de $X$. fastidiosa 9a5c (http://aeg.lbi.ic.unicamp.br/xf/).

${ }^{2}$ Wulff et al. (2003), exceto e-value de Xf-1940 (http://aeg.lbi.ic.unicamp.br/xf/).

\subsection{Extração de DNA cosmidial e plasmidial}

Para extração de DNA cosmidial e plasmidial as bactérias $E$. coli foram crescidas em meio LB (Anexo A) e alíquotas de $1,5 \mathrm{~mL}$ foram transferidas para microtubos de centrífuga, que foram centrifugados à $19.000 \times$ xg por 5 minutos a $4{ }^{\circ} \mathrm{C}$. O precipitado foi ressuspendido com $100 \mu \mathrm{L}$ de solução 1 (glicose $50 \mathrm{mM}$, Tris- $\mathrm{HCl} 25 \mathrm{mM} \mathrm{pH} \mathrm{8,0,}$ EDTA $10 \mathrm{mM}$ pH 8,0) gelada, em seguida foi adicionado $200 \mu \mathrm{L}$ da solução $2(\mathrm{NaOH}$ $0,2 \mathrm{~N}$, SDS $1 \%$ ) e homogeneizado por inversão dos tubos. Os tubos foram mantidos no gelo por 10 minutos, e então foi adicionado $150 \mu \mathrm{L}$ da solução 3 (acetato de potássio $5 \mathrm{M}, 11,5 \mathrm{~mL}$ ácido acético glacial, $28,5 \mathrm{~mL}$ água deionizada), misturando-se por 
inversão. Os tubos foram mantidos novamente no gelo por 10 minutos e, após este período, foram centrifugados a $19.000 \times$ xg por 20 minutos à $4^{\circ} \mathrm{C}$. $\mathrm{O}$ sobrenadante foi transferido para novos tubos e adicionou-se $1,5 \mu \mathrm{L}$ de RNAse $(10 \mathrm{mg} / \mathrm{mL})$. Os tubos foram incubados a $37^{\circ} \mathrm{C}$ por 20 minutos. O DNA foi precipitado com $1 \mathrm{~mL}$ de etanol absoluto gelado. Centrifugou-se a $19000 x g$ por 15 minutos à $4^{\circ} \mathrm{C}$, e o precipitado foi lavado com $750 \mu \mathrm{L}$ de etanol $70 \%$ centrifugando à $19000 x g$ por 15 minutos. O DNA precipitado foi seco a $37^{\circ} \mathrm{C}$ e ressuspendido em $30 \mu \mathrm{L}$ de água MilliQ esterilizada.

A extração de DNA foi observada através de eletroforese em gel de agarose $1 \%$ com tampão TAE $1 \mathrm{X}$ (Tris $40 \mathrm{mM}$ pH 7,6, ácido acético $20 \mathrm{mM}$, EDTA $1 \mathrm{mM}$ ) acrescido de $1 \mu \mathrm{L}$ de brometo de etídeo $(0,5 \mu \mathrm{g} / \mathrm{mL})$ para cada $100 \mathrm{~mL}$ de TAE $1 X$. O gel foi fotografado, depois da corrida, com fotodocumentador Kodak Digital Science ID, sob luz ultra-violeta (UV).

\subsection{Obtenção das ORFs alvo por Reação em Cadeia da Polimerase (PCR)}

Para obtenção das seqüências de DNA das ORFs selecionadas, foram preparados primers tomando-se por base a sequiência original das ORFs. $O$ grau de autocomplementariedade dos pares de primers foi avaliado através do programa Vector NTI $^{\otimes}$ Suíte (InforMax, Inc.). Nos primers foram inseridos seqüências de reconhecimento de enzimas de restrição, para facilitar a clonagem dos fragmentos de DNA nos plasmídeos vetores. A síntese foi feita em escala de 50 nmoles pela Life Technologies do Brasil Ltda (São Paulo, SP). A seqüência dos primers utilizados para amplificar cada ORF é apresentado na Tabela 2. 
Tabela 2. Primers* preparados para amplificação de fragmentos de DNA das ORFs selecionadas

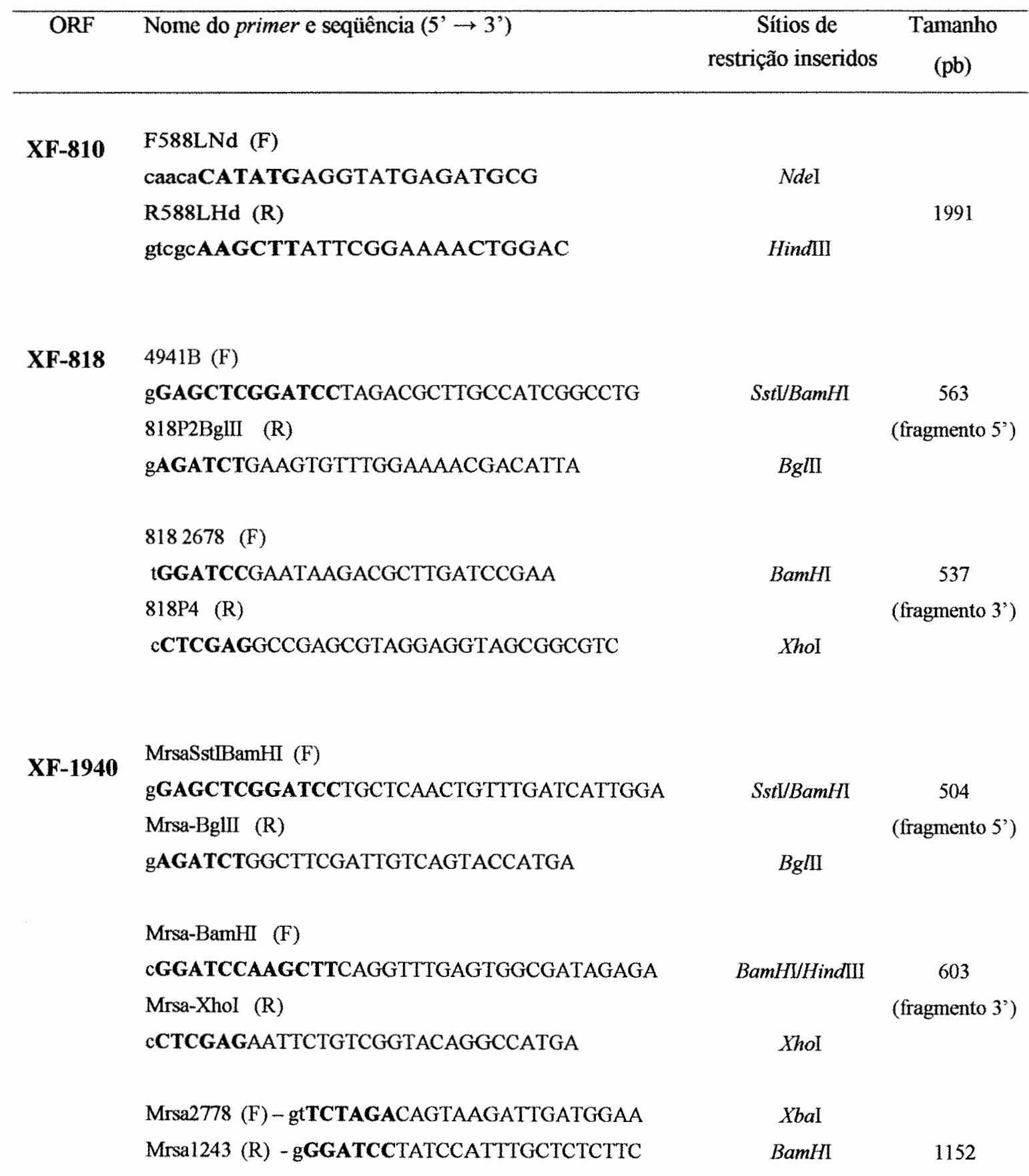


Tabela 2. Primers* preparados para amplificação de fragmentos de DNA das ORFs selecionadas

\begin{tabular}{|c|c|c|c|}
\hline ORF & Nome do primer e seqüência $\left(5^{\prime} \rightarrow 3^{\prime}\right)$ & $\begin{array}{c}\text { Sítios de } \\
\text { restrição inseridos }\end{array}$ & $\begin{array}{c}\text { Tamanho } \\
(\mathrm{pb})\end{array}$ \\
\hline XF-2708 & $\begin{array}{l}\text { 2708P1SstBamHI (F) } \\
\text { gGAGCTCGGATCCCACTGTACGAGGTGGGTCGT } \\
\text { 2708P2BgIII (R) } \\
\text { gAGATCTGCATAGAAAGGAAATAGGCATAG }\end{array}$ & $B g I I I$ & $\begin{array}{c}540 \\
\text { (fragmento 5') }\end{array}$ \\
\hline & $\begin{array}{l}2708 P 3(\mathrm{~F}) \\
\text { cGGATCCAAGCTTGATTATCCATTTAACCTG } \\
2708 \mathrm{P} 4 \text { (R) } \\
\text { cCTCGAGGGTGAGCTGTACTGAGCTG }\end{array}$ & $\begin{array}{c}\text { BamHI/HindIII } \\
\text { XhoI }\end{array}$ & $\begin{array}{c}606 \\
\text { (fragmento 3') }\end{array}$ \\
\hline XF-2359 & $\begin{array}{l}\text { PectatoP1SstBamHI (F) } \\
\text { gGAGCTCGGATCCCAATAAACTCAATCTGCGGTA } \\
\text { PectatoP2BgIII (R) } \\
\text { gAGATCTGTGATGTGGAGATTCGGTCATCG }\end{array}$ & Sst $\mathrm{I} / \mathrm{BamHI}$ & $\begin{array}{c}819 \\
\left.\text { (fragmento } 5^{\prime}\right)\end{array}$ \\
\hline & $\begin{array}{l}\text { Pectato2473 (F) } \\
\text { cGGATCCACGAAGCCATCAAAGACCTGC } \\
\text { Pectato2876 (R) } \\
\text { gCTCGAGGTGCGTTGTTTGATTTTATGT }\end{array}$ & XhoI & $\begin{array}{c}424 \\
\left.\text { (fragmento } 3^{\prime}\right)\end{array}$ \\
\hline
\end{tabular}

* Na seqüência de nucleotídeos dos primers as letras minúsculas representam os nucleotídeos adicionados para facilitar a amplificação do gene de interesse e a digestão do fragmento amplificado pelas enzimas de restrição, letras em negrito denotam sítios de restrição inseridos no primer. (F) - Primer "forward" se anela no sentido da transcrição. (R) - Primer "reverse" que é complementar à porção 3' do gene. 
Os primers foram diluídos em água para obter a concentração de $10 \rho$ moles $/ \mu \mathrm{L}$ e foram mantidos a $-20^{\circ} \mathrm{C}$. As reações de amplificação foram preparadas seguindo o padrão abaixo:

DNA $1 \mu \mathrm{L}(\sim 50 \mathrm{ng})$

Tampão PCR 1X (Gibco-BRL) $3 \mu \mathrm{L}$

$\mathrm{MgCl}_{2}(25 \mathrm{mM})$ $1 \mu \mathrm{L}$

dNTPs (Gibco-BRL) $(200 \mu \mathrm{M}$ de cada) $\ldots 1 \mu \mathrm{L}$

Primer "forward" $1 \mu \mathrm{L}$

Primer "reverse" $1 \mu \mathrm{L}$

Taq DNA polimerase (Gibco-BRL) ....... 1,5 U

Cada reação foi completada com água para se obter um volume final $30 \mu \mathrm{L}$.

As amplificações foram realizadas em termociclador PTC 100 (MJ Research) e foram iniciadas com desnaturação a $94^{\circ} \mathrm{C}$ por 3 minutos, seguidas de 35 ciclos de desnaturação a $94^{\circ} \mathrm{C}$ por 45 segundos, pareamento a $60^{\circ} \mathrm{C}$ por 30 segundos e extensão a $72{ }^{\circ} \mathrm{C}$ por 90 segundos. A extensão final foi realizada a $72{ }^{\circ} \mathrm{C}$ por 10 minutos.

Após a amplificação, os fragmentos foram separados por eletroforese em gel de agarose 1\% (TAE 1X) e purificados utilizando-se diferentes Kits como, GFX PCR DNA and Gel Band Purification Kit (cat. 27-9602-01, Amersham Biosciences), Wizard ${ }^{\circledR} \mathrm{SV}$ Gel and PCR Clean-Up System (cat. A9282, Promega) ou Concert ${ }^{\mathrm{TM}}$ Gel Extraction Systems (cat. 11456, Life Technologies) de acordo com as especificações dos fabricantes.

\subsection{Clonagem dos fragmentos amplificados por PCR}

Os fragmentos de DNA de $X$. fastidiosa, amplificados via PCR, foram clonados em vetores pGEM-T (kit pGEM ${ }^{\circledR}$-T Vector System - Promega) ou pCR ${ }^{\circledR} 4-T O P O$ (TOPO TA Cloning ${ }^{\text {Kit }}$ for Sequencing - Invitrogen) ou ainda, em vetor pUC18 utilizando-se o kit "SureClone ${ }^{\mathrm{TM}}$ Ligation kit" (Amersham Pharmacia Biotech), sem 
serem digeridos com as respectivas enzimas de restrição presentes nos primers produzidos.

Os vetores pGEM-T e pCR ${ }^{\circledR} 4-T O P O$ foram utilizados principalmente para a clonagem de produtos de PCR pois estes apresentam extremidades coesivas terminadas em adeninas (A) e os vetores apresentam no seu sítio de clonagem tiaminas (T).

A clonagem em pUC18 utilizando o kit "SureClone ${ }^{\mathrm{TM}}$ Ligation kit" foi feita, basicamente, através das seguintes etapas: reparo das extremidades dos fragmentos com as enzimas Klenow e T4 Polinucleotídeo quinase, purificação do inserto utilizando a coluna micro spin, e ligação no vetor pUC18 linearizado no sítio de clonagem da enzima SmaI, presentes no kit.

Para cada etapa de clonagem e subclonagem a reação de ligação entre vetor e inserto foi realizada utilizando a proporção molar de 1:4 entre vetor e inserto, respectivamente, $1 \mathrm{U}$ da enzima T4 DNA ligase (Gibco-BRL) e $2 \mu \mathrm{L}$ do tampão de ligação $\mathrm{T} 45 \mathrm{X}$, em um volume final de $15 \mu \mathrm{L}$, as reações de ligação eram submetidas à temperatura de $16^{\circ} \mathrm{C}$ por $14-16$ horas. $\mathrm{O}$ produto da ligação era utilizado para a transformação de células competentes de $E$. coli, visando à amplificação clonal do novo plasmídio.

\subsection{Transformação de $E$. coli com os produtos de ligação}

A transformação dos produtos de ligação em células competentes de Escherichia coli DH5 $\alpha$ (Hanahan et al., 1983) foi realizada adicionando-se $10 \mu \mathrm{L}$ da reação de ligação em tubo Eppendorf de $1,5 \mathrm{~mL}$ contendo $200 \mu \mathrm{L}$ de células competentes preparadas de acordo com o Anexo B. Essa mistura permaneceu no gelo por 20 minutos, e logo em seguida sofreu um choque térmico a $42{ }^{\circ} \mathrm{C}$ por 90 segundos, e os tubos foram transferidos imediatamente para o gelo permanecendo por 3 minutos. Em ambiente asséptico foi adicionado $1 \mathrm{~mL}$ de meio LB. A mistura foi incubada a $37^{\circ} \mathrm{C}$ por 1 hora, sob agitação de $220 \mathrm{rpm}$. Em seguida foi centrifugada por 1 minuto a $2.600 \mathrm{xg}$. Cerca de $500 \mu \mathrm{L}$ do sobrenadante foram descartados e as células foram ressuspendidas no volume 
restante, com auxílio de pipeta. Aproximadamente $50 \mu \mathrm{L}$ dessa suspensão foram espalhadas em placas de petri plásticas contendo meio LB sólido suplementado com ampicilina (100 mg/L) e $50 \mu \mathrm{L}$ da solução de X-Gal/IPTG (Anexo C), para avaliação da atividade de $\beta$-galactosidase (gene lacZ) nos transformantes e seleção destes após incubação a $37^{\circ} \mathrm{C}$ por 14 - 16 horas.

\subsection{Construção dos vetores para disrupção de Xylella fastidiosa}

Duas estratégias foram usadas para a construção dos vetores para disrupção dos genes alvo de $X$. fastidiosa:

(1) Disrupção pela substituição da ORF pelo gene yfp (proteína amarela fluorescente), obtido a partir de vetor pEYFP-SK (cedido pelo Dr.Eric Lam, Rutgers University, USA), para a disrupção das ORFs Xf-818, Xf-1940, Xf-2359 e Xf-2708;

(2) Disrupção pela inserção do cassete $l a c Z-\mathrm{Km}^{\mathrm{R}}$ (gene da $l a c Z$ fusionado a região codificadora do gene de resistência ao antibiótico canamicina) clonado a partir do plasmídeo pKOK6 (Kokotec \& Lotz, 1989). Esta estratégia foi utilizada para a disrupção das ORFs Xf-810 e Xf-1940.

Após a construção dos plasmídeos vetores de disrupção de $X$. fastidiosa, foi introduzido a origem de replicação cromossomal de $X$. fastidiosa (OriC) de $366 \mathrm{pb}$ ou de $1,9 \mathrm{~kb}$, obtidos respectivamente dos plasmídeos p16Kori e p16KdAori (Monteiro et al., 2001b), para permitir a transformação da bactéria.

\subsubsection{Estratégia de disrupção por substituição da ORF pelo gene $y f p$}

A metodologia utilizada para a construção dos plasmídeos vetores utilizando a estratégia de substituição da ORF de $X$. fastidiosa pelo gene $y f p$ está representada esquematicamente na Figura 1. 
Inicialmente, foram feitas amplificações de segmentos de nucleotídeos por PCR denominada de fragmentos 5' utilizando primers para amplificar um fragmento contendo 21 nucleotídeos da região $5^{\prime}$ codificadora da ORF mais uma sequência montante (upstream) à ORF. Para as ORFs Xf-818, Xf-1940, Xf-2359 e Xf-2708 foram amplificados fragmentos 5' de 563, 504, 819 e $540 \mathrm{pb}$, respectivamente.

Da mesma forma, foram obtidos os segmentos denominados de fragmentos $3^{\prime}$. Os primers utilizados amplificam um fragmento contendo alguns nucleotídeos da região 3' da ORF e mais um segmento ajusante (downstream) à ORF. Para as ORFs Xf-818, Xf-1940, Xf-2359 e Xf-2708 foram amplificados fragmentos 3' de 537, 603, 424 e 606 $\mathrm{pb}$, apresentando 58, 9, 29 e 102 nucleotídeos da região 3' codificadora das ORFs e o restante são nucleotídeos ajusante (downstream) à ORF, respectivamente. Os cosmídeos utilizados para amplificação de cada ORF estão descritos na Tabela 1 e a seqüência dos primers estão na Tabela 2.

Após eletroforese em gel de agarose $1 \%$, os fragmentos foram purificados e ligados nos plasmídeos vetores. Os fragmentos $5^{\prime}$ foram ligados em vetores pGEM-T e os fragmentos 3' foram ligados em vetores $\mathrm{pCR}^{\circledR} 4$-TOPO, exceto o fragmento 3 ' da ORF Xf-1940 que foi ligado em vetor pUC18.

Os plasmídeos contendo os fragmentos 3' foram digeridos com as enzimas de restrição BamHI e XhoI e esses fragmentos foram clonados em vetores pEYFP-SK digeridos com $B g l I I$ e $X h o I$. As enzimas BamHI e $B g I I I$ produzem segmentos que permitem a ligação das pontas coesivas, mas não recupera nenhum destes sítios de restrição após a ligação. Os plasmídeos resultantes foram digeridos com SstI e BamHI, onde foram clonados os fragmentos 5', liberados dos seus vetores pela digestão com as enzimas $S s t \mathrm{I}$ e $B g I I I$. Após a clonagem, cada plasmídeo produzido apresenta o gene $y f p$ flanqueado pelos fragmentos 5' e 3' das ORFs de $X$. fastidiosa.

O plasmídeo p16Kori foi digerido com a enzima de restrição BamHI liberando a sequêencia da OriC de 366 pb, a qual foi clonada no sítio de restrição da BamHI de cada um dos plasmídeos descritos acima, produzindo os plasmídeos finais usados para transformar Xylella fastidiosa. 
A.

Amplificação da região 5'

Amplificação da região 3 ,

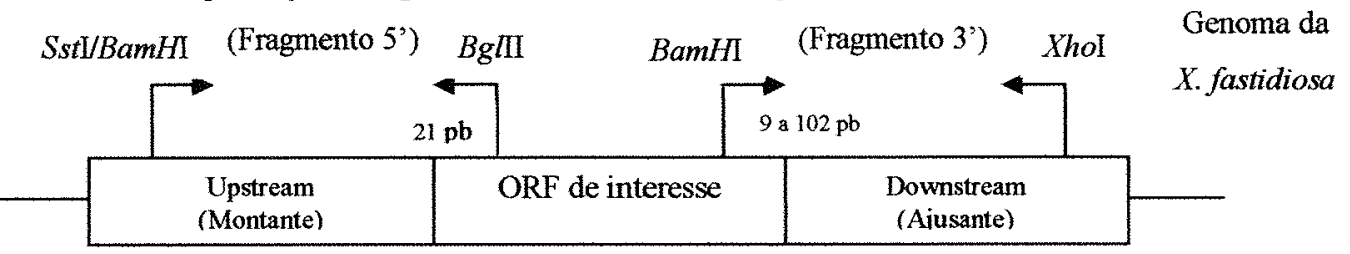

B.
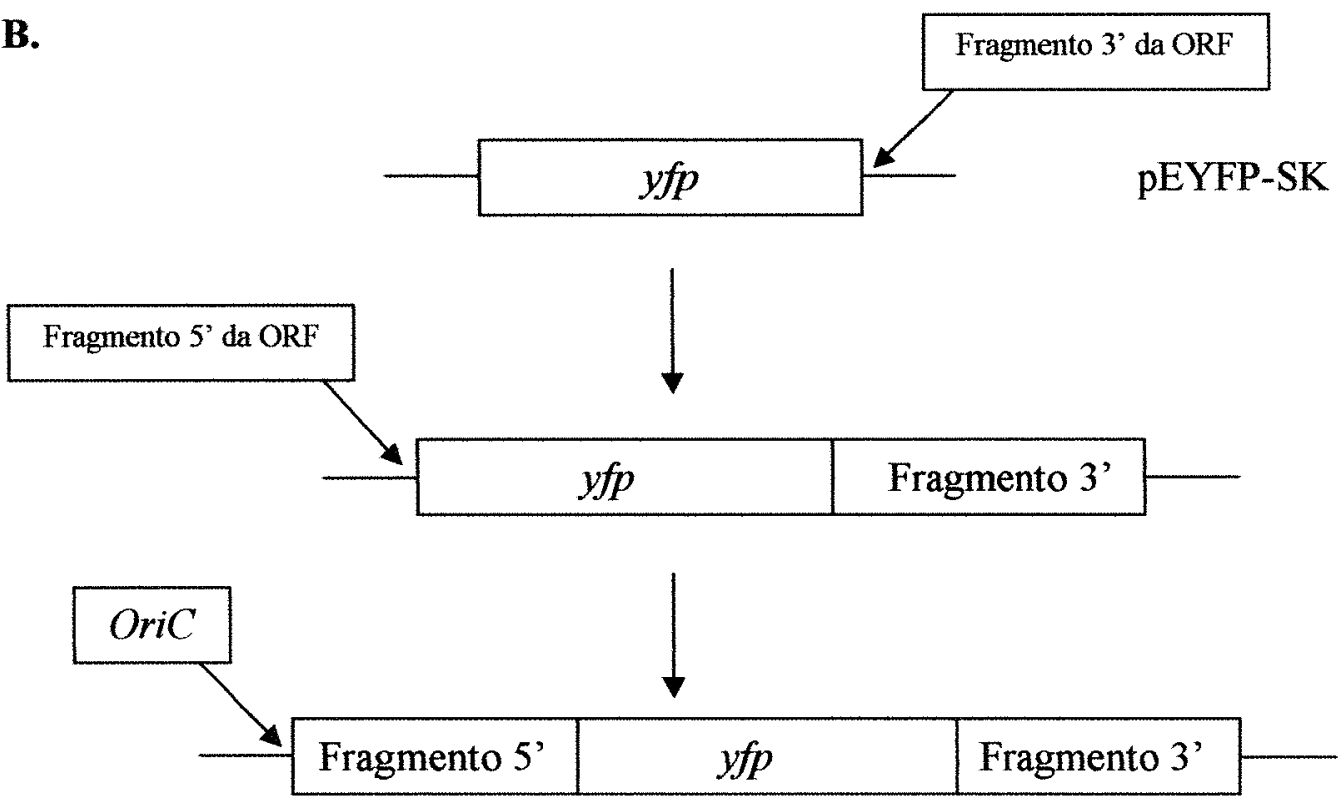

C.

\begin{tabular}{|l|l|l|l|}
\hline OriC & Fragmento 5' & $y f p$ & Fragmento 3' \\
\hline
\end{tabular}

Figura 1 - Esquema para a construção dos plasmídeos vetores para a disrupção das ORFs de Xylella por substituição pelo gene $y f p$. A. Amplificação dos fragmentos 5' e 3' das ORFs de interesse do genoma de $X$. fastidiosa por PCR. B. clonagem dos fragmentos 5' e 3' flanqueando a região codificadora do gene $y f p$ no plasmídeo pEYFP-SK e introdução da OriC de 366 pb do vetor p16Kori. C. Representação do plasmideo final que foi utilizado na transformação da bactéria $X$. fastidosa 


\subsubsection{Estratégia de disrupção por inserção do cassete lacZ-Km ${ }^{\mathrm{R}}$}

A metodologia utilizada para a construção dos plasmídeos vetores para a disrupção da ORF de $X$. fastidiosa utilizando a estratégia da inserção do cassete lacZ$\mathrm{Km}^{\mathrm{R}}$ está representada esquematicamente na Figura 2.

Foram feitas, inicialmente, amplificações de fragmentos de 1767 e $1152 \mathrm{pb}$ das ORFs Xf-810 e Xf-1940, respectivamente, utilizando os primers F588LNd e R588LHd para a ORF Xf-810 e os primers Mrsa1243 e Mrsa2778 para a ORF Xf-1940 (Tabela 2). O fragmento da ORF Xf-810 contém 69 nucleotídeos da região ajusante à ORF, enquanto o fragmento da ORF Xf-1940 contém 180 nucleotídeos da região montante e 321 nucleotídeos da região ajusante à ORF. Cada fragmento das ORFs foram clonados no sítio de restrição SmaI do vetor pUC18 ("SureClone ${ }^{\mathrm{TM}}$ Ligation kit"-Amersham Pharmacia Biotech), conforme descrito no item 3.4. O fragmento contendo a ORF Xf810 resultou no plasmideo pNAW22 preparado por Nelson Wulff (Wulff, 2002) e o fragmento da ORF Xf-1940 resultou no plasmídeo pSG50.

Como a ORF Xf-810 apresenta no seu interior dois sítios de restrição para a enzima $B g I I I$, pNAW22 foi digerido com esta enzima para inserir o cassete lacZ-Km ${ }^{\mathrm{R}}$ isolado do plasmídeo pKOK6 (Kokotec \& Lotz, 1989), pela digestão com BamHI para liberar o cassete com $4,7 \mathrm{~kb}$, que foi ligado no sítio $B g l I I$ da ORF Xf-810, e produziu o plasmídeo pSG30. Este plasmídeo apresenta o cassete $l a c Z-\mathrm{Km}^{\mathrm{R}}$ interrompendo a ORF Xf-810, dividindo o fragmento em duas regiões, a região 5' com 322 nucleotídeos e a região 3' com 384 nucleotídeos.

Para finalizar a construção do plasmídeo vetor de disrupção da ORF Xf-810 foi inserida a seqüência da OriC para permitir a transformação de $X$. fastidiosa. A OriC de $366 \mathrm{pb}$ foi digerida do plasmídeo pl6Kori com a enzima $B a m H I$ e foi inserida no mesmo sítio de restrição presente no plasmídeo pSG30, resultando no plasmídeo final pSG31.

Já o plasmídeo pSG50, apresenta dois sítios para a enzima PstI, sendo um sítio localizado no interior da ORF Xf-1940 e outro localizado no vetor adjacente a região 5' dessa ORF. Este plasmídeo foi parcialmente digerido com a enzima Pst, inserindo no sítio interno da ORF o cassete $l a c Z-\mathrm{Km}^{\mathrm{R}}$, digerido do plasmideo pKOK6 com a mesma 
enzima, PstI, resultando no plasmídeo pSG51. Este plasmídeo apresenta o cassete lacZ$\mathrm{Km}^{\mathrm{R}}$ nterrompendo a ORF e dividindo o fragmento em duas regiões a região 5' com 633 nucleotídeos e a região 3'com 519 nucleotídeos.

A partir do plasmídeo pSG51 foram construídos dois plasmídeos para disrupção da ORF Xf-1940 em $X$. fastidiosa. Primeiramente pSG51 foi parcialmente digerido com BamHI, pois apresenta dois sítios de restrição para esta enzima localizados nas extremidades dos fragmentos 5' e 3'. Em um dos sítios foi clonada separadamente a OriC de $366 \mathrm{pb}$ e outra de $1,9 \mathrm{~kb}$, digeridas também com BamHI dos plasmídeos p16Kori e p16KdAori, respectivamente. As construções finais resultantes foram os plasmídeos pSG52 (com OriC de 366 pb) e pSG53 (com OriC de 1,9 kb). 
A.

\section{BamHI/PstI}

PstI/BamHI

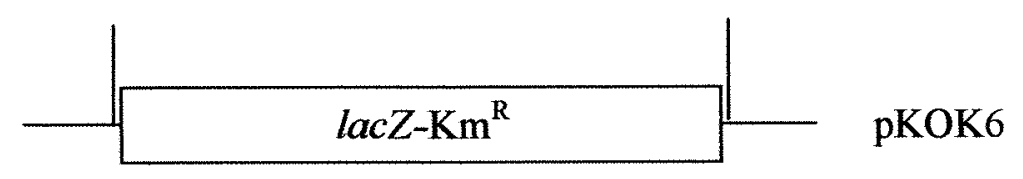

B.

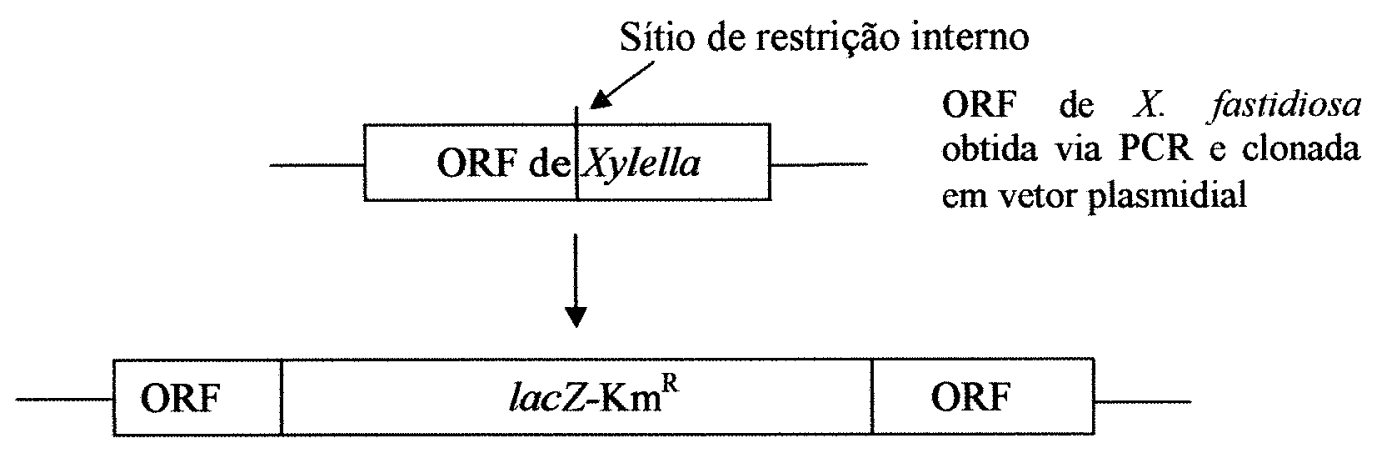

C.

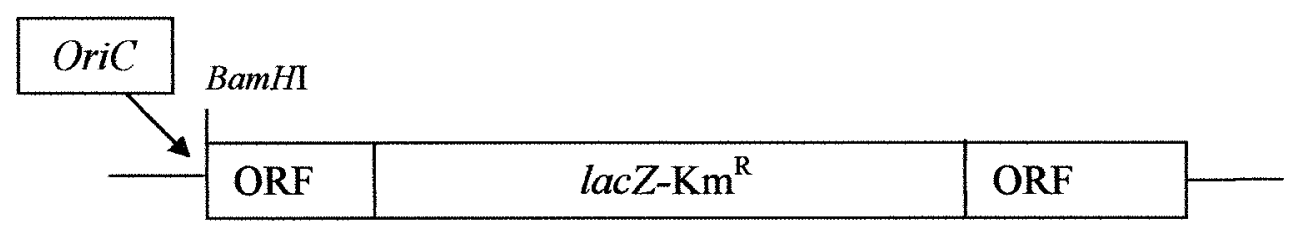

D.

\begin{tabular}{|l|l|l|l|}
\hline OriC & ORF & lacZ-Km & ORF \\
\hline
\end{tabular}

Figura 2 - Esquema para a construção dos plasmídeos vetores para a disrupção das ORFs Xf-810 e Xf-1940, utilizando o cassete lacZ-Km ${ }^{\mathrm{R}}$. A. Representação do plasmídeo pKOK6, progenitor do cassete $l a c Z-\mathrm{Km}^{\mathrm{R}}$. B. Representação dos plasmídeos vetores contendo as ORFs de interesse, demonstrando o sítio interno específico das enzimas de restrição, BgIII ou Pst $\mathrm{I}$, local de inserção do cassete lacZ-Km ${ }^{\mathrm{R}}$. C. Demonstração da inserção da OriC de $366 \mathrm{pb}$ ou de $1,9 \mathrm{~kb}$ no sítio da BamHI externo à ORF. D. Representação do plasmídeo final para transformação de $X$. fastidiosa 


\subsection{Confirmação da identidade dos plasmídeos de disrupção de $X$. fastidiosa}

Após cada etapa de clonagem os plasmídeos produzidos foram digeridos com enzimas específicas para a verificação da presença do inserto, e aqueles que apresentaram o fragmento de tamanho esperado foram seqüenciados para confirmar novamente a identidade dos clones e se as seqüências estavam de acordo com o quadro aberto de leitura, para expressão da proteína codificada pelo gene inserido.

As reações de PCR de seqüenciamento foram feitas em placa de seqüenciamento (MicroAmp ${ }^{\circledR}$ Optical 96 - Well Reaction Plate, Applied Biosystems) utilizando 10 pmoles/ $\mu \mathrm{L}$ do primer M13/pUC - Reverse (5'-AGCGGATAACAATTTCACACAGG3') ou M13/pUC-Forward (5'-CCCAGTCACGACGTTGTAAAACG-3'), ou ainda primers específicos utilizados nas amplificações por PCR dos fragmentos, dependendo do plasmídeo sendo analisado, $2 \mu \mathrm{L}$ de tampão de seqüenciamento, $100 \mathrm{ng}$ de DNA plasmidial e $2 \mu \mathrm{L}$ do reagente de seqüenciamento (kit Big Dye ${ }^{\mathrm{TM}}$ Terminator - Perkin Elmer Biosystems). O volume final foi de $10 \mu \mathrm{L}$ completado com água MilliQ. Utilizouse para as reações termociclador (GeneAmp ${ }^{\circledR}$ PCR System 9700 - Applied Biosystems) iniciando com desnaturação à $96^{\circ} \mathrm{C}$ por 2 minutos, seguidas de 35 ciclos de desnaturação à $96^{\circ} \mathrm{C}$ por 45 segundos, pareamento à $50^{\circ} \mathrm{C}$ por 30 segundos e extensão à $60^{\circ} \mathrm{C}$ por 4 minutos. A extensão final foi realizada a $60^{\circ} \mathrm{C}$ por 2 minutos.

Para retirar os sais do tampão, bem como os nucleotideos fluorescentes não incorporados, fez-se a purificação da amostra adicionando-se $60 \mu \mathrm{L}$ de isopropanol $75 \%$ (preparado no momento de utilização) ao volume de $10 \mu \mathrm{L}$ da reação de PCR e agitou-se vigorosamente 20 vezes. A placa de seqüenciamento foi mantida 20 minutos em temperatura ambiente e no escuro. Centrifugou-se por 45 minutos a $2.250 \mathrm{xg}$ e o sobrenadante foi descartado. O precipitado foi lavado com $150 \mu \mathrm{L}$ de etanol $70 \%$ (a temperatura ambiente) e centrifugado 10 minutos a $2.250 \mathrm{xg}$. O sobrenadante foi descartado e o precipitado foi seco no escuro a temperatura ambiente por 2 horas e armazenado em refrigerador $\left(4^{\circ} \mathrm{C}\right)$, até o momento do seqüenciamento. 
Imediatamente antes do seqüenciamento adicionou-se $10 \mu \mathrm{L}$ de formamida a cada reação de seqüenciamento purificada e a placa foi agitada durante 30 segundos, 0 DNA foi desnaturado por 5 minutos a $95^{\circ} \mathrm{C}$ e as reações foram colocadas no gelo. $\mathrm{O}$ seqüenciamento foi feito em seqüenciador capilar automático ABI-3100 (Applied Biosystems/Hitachi) de acordo com instruções do fabricante.

As seqüências obtidas foram comparadas com as seqüências do banco de dados da $X$. fastidiosa (http://aeg.lbi.ic.unicamp.br/xf), para confirmar a identidade da seqüência de DNA.

Para analisar se o códon de iniciação (ATG) do gene yfp estava na mesma seqüência de tradução das ORFs, foram feitos seqüenciamentos (como descrito anteriormente) utilizando separadamente os primers "forward" dos fragmentos 5' e o primer "reverse" P1EY(G)FP (Tabela 3), que se pareia na região interna do gene $y f p$. Essas seqüências foram analisadas no programa Vector NTI Suite v .6.0 (InforMax, Inc. USA).

Todas as culturas de $E$. coli contendo os plasmídeos construídos corretamente foram misturadas em igual proporção com uma solução de glicerol 100\% esterilizada por autoclavagem, e armazenadas em ultracongelador a $-80^{\circ} \mathrm{C}$, para fazer parte do estoque de clones produzidos pelo laboratório para que possam ser utilizadas em pesquisas no futuro.

\subsection{Análise da expressão dos genes $y f p$ e $l a c Z-\mathrm{Km}^{\mathrm{R}}$ das construções finais em $E$. coli}

A expressão do gene $y f p$, nos plasmídeos finais contendo este gene foi observada após inoculação das bactérias em lâmina de microscópio e observação da expressão da proteína YFP feita em microscópio Fluorescent Microscope Axioplan 2 (Zeiss), Depto. de Genética ESALQ/USP, utilizando o mesmo filtro que é utilizado para expressão do gene $g f p$ (proteína verde fluorescente), luz UV.

Para os testes de resistência ao antibiótico canamicina e expressão do gene lac $Z$, as bactérias $E$. coli transformadas com as construções contendo o cassete lacZ-Km ${ }^{\mathrm{R}}$ 
foram inoculadas em meio LB sólido suplementado com o antibiótico canamicina (50 $\mathrm{mg} / \mathrm{L}$ ) e $50 \mu \mathrm{L}$ da solução X-Gal/IPTG espalhado nas placas, 30 minutos antes da inoculação das bactérias. A confirmação ocorreu devido a resistência ao antibiótico canamicina e a visível coloração azul das colônias de bactérias $E$. coli.

\subsection{Cultivo da bactéria Xylella fastidiosa}

A linhagem de Xylella fastidiosa utilizada foi a J1a12 (Monteiro et al., 2001b). Esta linhagem foi isolada de plantas de citros, sintomáticas para a CVC, coletadas na região de Jales, estado de São Paulo.

O meio de cultura utilizado para $X$. fastidiosa foi o PW (Davis et al., 1978) que contém os ingredientes abaixo, em cada litro de meio preparado:

\begin{tabular}{|c|c|}
\hline 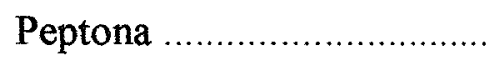 & $4 \mathrm{~g}$ \\
\hline 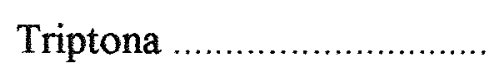 & $1 \mathrm{~g}$ \\
\hline $\mathrm{K}_{2} \mathrm{HPO}_{4} \ldots \ldots \ldots$ & $1,2 \mathrm{~g}$ \\
\hline $\mathrm{KH}_{2} \mathrm{PO}_{4} \ldots \ldots \ldots \ldots \ldots \ldots \ldots \ldots \ldots \ldots \ldots \ldots$ & $1 \mathrm{~g}$ \\
\hline $\mathrm{MgSO}_{4} .7 \mathrm{H}_{2} \mathrm{O}$ & $0,4 \mathrm{~g}$ \\
\hline Hemina clorada $(0,1 \%) \ldots \ldots$ & $10 \mathrm{~mL}$ \\
\hline Vermelho de fenol $(0,2 \%) \ldots$ & $10 \mathrm{~mL}$ \\
\hline Água destilada . & $850 \mathrm{~mL}$ \\
\hline Ágar & $10 \mathrm{~g}$ \\
\hline
\end{tabular}

Após autoclavagem (20 minutos), com o meio resfriado por volta de $60^{\circ} \mathrm{C}$, adicionou-se, sob condições assépticas, $80 \mathrm{~mL}$ de L-Glutamina (4\%), $30 \mathrm{~mL}$ de albumina de soro bovino fração V (BSA) (10\%) e $20 \mathrm{~mL}$ de solução de glicose $50 \%$. Estas soluções foram previamente esterilizadas por filtração (filtro de 0,2 $\mu \mathrm{m}$ ).

O cultivo de $X$. fastidiosa ocorreu a $28^{\circ} \mathrm{C}$ sob agitação constante de $100 \mathrm{rpm}$. A subcultura da bactéria para meio fresco foi realizada em uma diluição de $1 / 10$, a cada sete dias. 


\subsection{Preparo de células competentes e transformação de Xylella fastidiosa}

Para o preparo de células competentes, uma colônia de $X$. fastidiosa crescendo em meio sólido PW foi inoculada em $0,5 \mathrm{~mL}$ de PW liquido. Após sete dias de cultivo a $28^{\circ} \mathrm{C}$ e $100 \mathrm{rpm}$ adicionou-se $2 \mathrm{~mL}$ de meio $\mathrm{PW}$, após 7 dias novamente adicionou-se 25 $\mathrm{mL}$ de meio $\mathrm{PW}$ e 7 dias depois adicionou-se mais $250 \mathrm{~mL}$ de meio $\mathrm{PW}$, após mais 7 dias esta cultura foi utilizada para preparo de células competentes.

No preparo de células competentes todos as etapas eram feitas de maneira a deixar as células em temperaturas baixas (gelo) para aumentar a eficiência das células competentes. A cultura de $250 \mathrm{~mL}$ foi transferida para tubo de polipropileno gelado e centrifugada a $2.600 \mathrm{xg}$ por 15 minutos a $4{ }^{\circ} \mathrm{C}$. O precipitado foi ressuspendido, com auxílio de pipeta, em $200 \mathrm{~mL}$ de água MilliQ gelada e centrifugado a $2.600 \mathrm{xg}$ por 15 minutos a $4{ }^{\circ} \mathrm{C}$. As bactérias precipitadas foram ressuspendidas em $200 \mathrm{~mL}$ de solução de glicerol $(10 \%)$ gelada e foram novamente centrifugadas como descrito. O precipitado final foi ressuspendido em $1,0 \mathrm{~mL}$ de glicerol $10 \%$ e aliquotas de $100 \mu \mathrm{L}$ foram transferidas para microtubos de centrífuga, previamente gelados que foram congelados em nitrogênio liquido e estocados em ultracongelador $\left(-80^{\circ} \mathrm{C}\right)$.

Para a transformação $100 \mu \mathrm{L}$ de células competentes foram mantidas no gelo durante 10 minutos. Em seguida, adicionou-se $1 \mu \mathrm{g}$ de DNA plasmidial e a mistura de células competentes de $X$. fastidiosa e DNA foi transferida para cubeta de eletroporador de $0,2 \mathrm{~cm}$ (Bio-Rad, cat. $\mathrm{n}^{\circ}$ 165-2086), estéril e gelada. As células foram transformadas em eletroporador GenePulser (Bio-Rad), utilizando $2,5 \mathrm{kV}$ de potência, $200 \Omega$ de resistência, e um campo de $25 \mu \mathrm{F}$. Imediatamente após a aplicação da corrente elétrica as células foram ressuspendidas em $1 \mathrm{~mL}$ de meio $\mathrm{PW}$, transferidas para tubos de $15 \mathrm{~mL}$ e incubadas a $28^{\circ} \mathrm{C}$ e $100 \mathrm{rpm}$ por 24 horas. Para a seleção dos transformantes $150 \mu \mathrm{L}$ das culturas transformadas foram plaqueadas em duas placas com meio PW sólido contendo ou não o antibiótico canamicina $(5 \mathrm{mg} / \mathrm{L})$, quando utilizado o vetor para disrupção do gene com $l a c Z-\mathrm{Km}^{\mathrm{R}}$. Quando utilizado o vetor para disrupção com o gene $y f p$ não foi utilizado antibiótico no meio de seleção. As placas foram envolvidas em 
Parafilme e incubadas a $28^{\circ} \mathrm{C}$ até o surgimento das colônias. $\mathrm{O}$ restante das culturas transformadas foram cultivadas em meio PW líquido e subcultivadas a cada sete dias, para posterior extração de DNA genômico e análises da eficiência do método de transformação.

\subsection{Extração de DNA de $X$. fastidiosa}

A extração de DNA de Xylella fastidiosa foi realizada utilizando $30 \mathrm{~mL}$ de cultura de células crescidas por uma semana que foi centrifugada por 15 minutos a $9.700 \times \mathrm{xg}$ e seu sobrenadante descartado. O precipitado de células formado foi ressuspendido em $567 \mu \mathrm{L}$ de TE (Tris- $\mathrm{HCl} 10 \mathrm{mM}$ pH 8,0, EDTA $1 \mathrm{mM}$ pH 8) e em seguida adicionou-se a $30 \mu \mathrm{L}$ de SDS $10 \%, 6 \mu \mathrm{L}$ de proteinase $\mathrm{K}(10 \mathrm{mg} / \mathrm{mL})$ e $5 \mu \mathrm{L}$ de RNase $(10 \mathrm{mg} / \mathrm{mL})$. Após agitação, a mistura foi incubada a $37{ }^{\circ} \mathrm{C}$ durante 1 hora. Foram então adicionados $100 \mu \mathrm{L}$ de $\mathrm{NaCl} 5 \mathrm{M}$ e $80 \mu \mathrm{L}$ de CTAB $10 \%$ (Anexo D) e incubou-se novamente por 10 minutos à $65^{\circ} \mathrm{C}$. Em seguida adicionou-se $700 \mu \mathrm{L}$ de uma solução de clorofórmio:álcool isoamílico (24:1, v:v). A solução foi homogeneizada por agitação manual e centrifugada a $19.000 \times \mathrm{xg}$ por 10 minutos. A fase superior foi transferida para novo tubo e foi adicionado $700 \mu \mathrm{L}$ de solução de fenol:clorofórmio:álcool isoamílico (25:24:1, v:v:v), em seguida a solução foi homogeneizada por agitação e centrifugada a $19.000 \times$ g por 10 minutos. A fase superior foi novamente transferida para novo tubo e o DNA foi então precipitado, adicionando-se $500 \mu \mathrm{L}$ de isopropanol, homogeneizando-se por inversões do tubo e deixado a temperatura ambiente por 15 minutos. $O$ tubo foi então centrifugado por 15 minutos a 4 ${ }^{\circ} \mathrm{C}$ e $19.000 x g$, e o DNA precipitado foi a seguir lavado com $1,5 \mathrm{~mL}$ de etanol $70 \%$. $\mathrm{O}$ DNA foi seco e ressuspendido em $50 \mu \mathrm{L}$ de água MilliQ estéril. 


\subsection{Confirmação do isolado de $X$. fastidiosa}

Para a confirmação do isolado de Xylella fastidiosa uma alíquota do DNA obtido $(\sim 50 \mathrm{ng})$ foi utilizada para amplificação por PCR de uma região específica do genoma de $X$ fastidiosa. Para isso foram utilizados os primers CVC1 (5'AGATGAAAACAATCATGCAAA-3') e CVC272-2int. (5'GCCGCTTCGGAGAGCATTCCT-3'), que foram delineados a partir de uma inserção de 28 nucleotídeos, presente apenas nos isolados de $X$. fastidiosa que causam CVC (Pooler \& Hartung, 1995b).

As condições utilizadas para a amplificação foram: $1 \mu \mathrm{L}$ de tampão PCR $1 \mathrm{X}$ (Gibco-BRL), $1 \mu \mathrm{L}$ de $\mathrm{MgCl}_{2}(25 \mathrm{mM}$ ), $200 \mu \mathrm{M}$ de cada dNTPs (Gibco-BRL), $1 \mu \mathrm{L}$ de cada primer $(10 \rho$ moles $/ \mu \mathrm{L})$ e 1,5 U de Taq DNA polimerase (Gibco-BRL), em um volume final de $30 \mu \mathrm{L}$. A amplificação foi realizada em termociclador PTC 100 (MJ Research) e foi iniciada com desnaturação a $94^{\circ} \mathrm{C}$ por 3 minutos, seguidas de 35 ciclos de desnaturação a $94^{\circ} \mathrm{C}$ por 1 minuto, anelamento a $50^{\circ} \mathrm{C}$ por 1 minuto e extensão a 72 ${ }^{\circ} \mathrm{C}$ por 1 minuto. A extensão final foi realizada a $72{ }^{\circ} \mathrm{C}$ por 5 minutos. Os produtos do PCR foram separados por eletroforese em gel de agarose 1\% (TAE 1X).

\subsection{Confirmação da obtenção de $X$. fastidiosa transformada}

Para a confirmação da transformação de $X$. fastidiosa foi isolado DNA genômico a partir de uma cultura de $25 \mathrm{~mL}$ crescida por uma semana após a transformação, conforme item 3.10. Em seguida $1 \mu \mathrm{L}(\sim 50 \mathrm{ng})$ deste DNA foi utilizado para a reação de PCR utilizando a combinação de primers: (1) CVC1 e CVC272-2int, para confirmação do isolado de Xylella fastidiosa; (2) o primer "forward" do fragmento 5' e o primer P1EY(G)FP (interno ao gene yfp) (Tabela 3) ou (3) o primer "reverse" do fragmento 3' e o primer "forward" P2EY(G)FP (interno ao gene $y f p$ ) (Tabela 3), confirmando a 
presença do fragmento presente no plasmídeo contendo a ORF interrompida pelo gene $y f p$, na amostra de DNA analisada.

Para se ter certeza da ocorrência da integração do gene yfp e do cassete lacZ$\mathrm{Km}^{\mathrm{R}}$ no genoma da $X$. fastidiosa, foram utilizados primers específicos do genoma da bactéria em conjunto com primer PlEY(G)FP, interno ao gene $y f p$, ou primer $\mathrm{KM}$ Antisense, interno ao cassete $l a c Z-\mathrm{Km}^{\mathrm{R}}$, usados para a disrupção das ORFs alvo deste trabalho (Tabela 3).

Para a confirmação da disrupção da ORF Xf-1940 com o cassete $l a c Z-\mathrm{Km}^{\mathrm{R}}$ (pSG52 e pSG53) foi utilizado os primers Mrsa-Xhol (Tabela 2) e o KM Antisense (Tabela 3).

As bactérias $X$. fastidiosa contendo as ORFs alvo substituídas com o gene $y f p$ foram testadas com os primers: P1EY(G)FP e um primer externo à ORF, não presente no plasmídeo usado na transformação da bactéria. As bactérias $X$. fastidiosa contendo as ORFs alvo interrompidas pelo cassete $l a c Z-\mathrm{Km}^{\mathrm{R}}$ foram analisadas pela amplificação de um fragmento de DNA com os primers KM Antisense (interno à lacZ-Km ${ }^{\mathrm{R}}$ ) e um primer externo às ORFs não presente nos plasmídeos de transformação (Tabela 3). 
Tabela 3. Primers utilizados para a confirmação da disrupção das ORFs de interesse

\begin{tabular}{|c|c|}
\hline ORF & Nome do primer e seqüência $\left(5^{\prime} \rightarrow 3^{\prime}\right)$ \\
\hline \multirow[t]{2}{*}{$\mathrm{Xf}-810$} & XF810R (reverse) \\
\hline & $5^{\prime}$ - CGTTAGGCAACTGCGGAGC - 3' \\
\hline \multirow[t]{2}{*}{$X f-818$} & XF818 (forward) \\
\hline & $5^{\prime}$ - CCCATAGCCGACAAACACCA - $3^{\prime}$ \\
\hline \multirow[t]{2}{*}{$\mathrm{Xf}-2708$} & XF2708 (forward) \\
\hline & $5^{\prime}$ - GCGGGAGTACCTGCGTTGTAC - 3' \\
\hline \multirow[t]{2}{*}{ Xf-1940 } & XF1940 (forward) \\
\hline & 5' - GTGCGCCATTGATTTCCAACG - 3' \\
\hline \multirow[t]{8}{*}{$\mathrm{Xf}-2359$} & XF2359 (forward) \\
\hline & 5' - GCCTCACTCAGCGGCTGCAA - 3' \\
\hline & KM Antisense (forward) \\
\hline & $5^{\prime}$ - TCACCGAGGCAGTTCCATA - 3' \\
\hline & PIEY(G)FP (reverse) \\
\hline & 5'-GCCCTCGCCGGACACGCTG-3' \\
\hline & P2EY(G)FP (forward) \\
\hline & 5'-CGGGATCACTCTCGGCATG-3' \\
\hline
\end{tabular}




\section{RESULTADOS}

\subsection{ORFs alvo selecionadas e as estratégias de disrupção destas ORFs em $X$. fastidiosa}

A análise do genoma da $X$. fastidiosa (Simpson et al., 2000) identificou as ORFs Xf-810, Xf-818 e Xf-2708 que apresentam similaridade com endoglicanases, a ORF Xf2359 com similaridade a pectato liase e a ORF Xf-1940 apresentando similaridade com a adesina MsrA e devido a importância comprovada destas enzimas na patogenicidade de alguns microorganismos, foram escolhidas para serem estudadas neste trabalho.

Estas ORFs de $X$. fastidiosa foram clonadas a partir de cosmídeos utilizados no programa de seqüenciamento do genoma da bactéria, efetuado pela rede ONSA (http://aeg.lbi.ic.unicamp.br/xf/).

Duas estratégias foram usadas para a construção de vetores para distupção das ORFs alvo de $X$. fastidiosa e obtenção de bactérias mutantes. Uma das estratégias utilizadas foi a disrupção das ORFs Xf-818, Xf-1940, Xf-2359 e Xf-2708 pela substituição da ORF pelo gene $y f p$, que codifica a proteína amarela fluorescente. A outra estratégia foi a disrupção das ORFs pela inserção do cassete lacZ- $\mathrm{Km}^{\mathrm{R}}$, esta estratégia foi utilizada para a construção dos vetores de disrupção das ORFs Xf-810 e Xf-1940. 


\subsection{Construção dos vetores para disrupção das ORFs por substituição pelo gene $y f p$}

\subsubsection{PCR e clonagem dos fragmentos 3' e 5'}

Inicialmente foram feitos reações de PCR, com os primers descritos na Tabela 2 , para amplificação dos fragmentos $3^{\prime}$ e 5' das ORFs Xf-818, Xf-1940, Xf-2359 e Xf2708, utilizando DNA isolado dos cosmídeos XF-07H04, XF-03H12, XF-07A02 e XF07B07, respectivamente.

A Figura 3 mostra os fragmentos dos genes de interesse amplificados a partir de DNA cosmidial. Pode-se observar que os fragmentos obtidos possuem os respectivos tamanhos esperados, conforme listado na Tabela 2.

Os fragmentos 3'e 5' das ORFs de interesse obtidos, foram purificados do gel de agarose e inseridos em vetores pUC18 (fragmento 3' da ORF Xf-1940) e pCR ${ }^{\circledR} 4-T O P O$ (fragmentos 3' das ORFs Xf-818, Xf-2359 e Xf-2708) e em vetor pGEM-T (fragmentos $\left.5^{\prime}\right)$, utilizando as metodologias específicas para cada vetor, e foram transformados em $E$. coli. Após 14 horas de cultivo, colônias brancas e com resistência a ampicilina, que possivelmente continham o DNA recombinante, foram selecionadas e cultivadas para extração do DNA dos plasmídeos.

A confirmação da clonagem dos fragmentos $3^{\prime}$ foi feita digerindo-se os plasmídeos com as enzimas BamHI e XhoI, enquanto na confirmação da clonagem dos fragmentos 5' foram utilizadas as enzimas $S s t \mathrm{I}$ e $B g l \mathrm{II}$. Estes sítios de restrição foram inseridos nos primers empregados para a amplificação dos fragmentos de DNA de $X$. fatidiosa, de forma a permitir as subclonagens posteriores.

Desta forma foram confirmadas as clonagens dos fragmentos 3' e 5' das ORFs Xf-818, Xf-1940, Xf-2359 e Xf-2708 através do perfil de cada restrição, que originava uma banda com tamanho esperado para o fragmento 3' de 537 pb (Xf-818), 603 pb (Xf$1940), 424 \mathrm{pb}(\mathrm{Xf}-2359)$ e $606 \mathrm{pb}(\mathrm{Xf}-2708)$ e outra banda com os vetores pUC18 de 2.686 pb para o fragmento 3' da ORF Xf-1940 e o pCR ${ }^{\circledR}$-TOPO de 3.954 pb para os fragmentos 3' das ORFs Xf-818, Xf-2359 e ORF Xf-2708 (Figura 4A). 
Com estes resultados, foi então confirmado a construção dos plasmídios pSG1, pVF2, pSG12 e pSG21 que contém, respectivamente, os fragmentos 3' das ORFs Xf818, Xf-1940, Xf-2359 e Xf-2708.

Também foi confirmado a construção dos plasmídios pSG2, pSG55, pSG11 e pSG22 contendo, respectivamente, os fragmentos 5' de 563 pb, 504 pb, 819 pb e 540 pb das ORFs Xf-818, Xf-1940, Xf-2359 e Xf-2708, respectivamente, clonados em vetores pGEM-T de 3000 pb (Figura 4B).

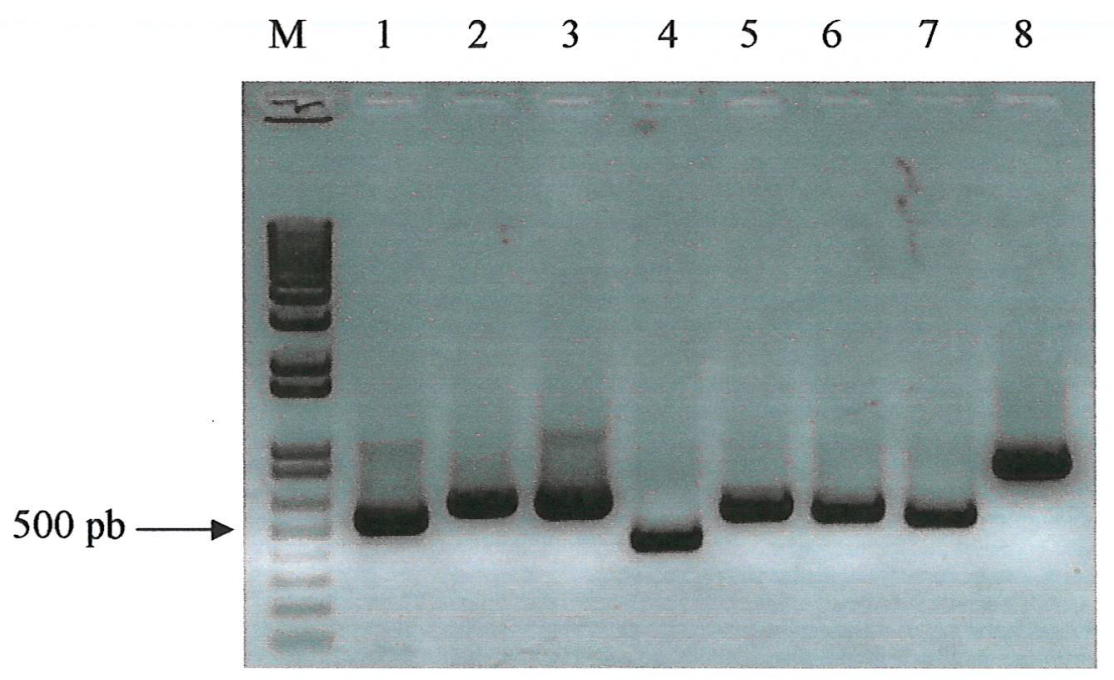

Figura 3 - Obtenção dos fragmentos 3' e 5' das ORFs de interesse amplificados através de PCR e separados em gel de agarose $1 \%$. Foram empregados os iniciadores descritos na Tabela 2. Linhas de 1 a 4: apresentam os fragmentos 3' das ORFs Xf-818 (537 pb), Xf-2708 (606 pb), 1940 (603 pb) e Xf-2359 (424 pb). Linhas de 5 a 8: apresentam os fragmentos 5' das ORFs Xf-818 (563 pb), Xf-2708 (540 pb), Xf-1940 (504 pb) e Xf-2359 (819 pb). M Marcador de massa molecular $1 \mathrm{~kb}$ plus DNA Ladder (Gibco BRL) 

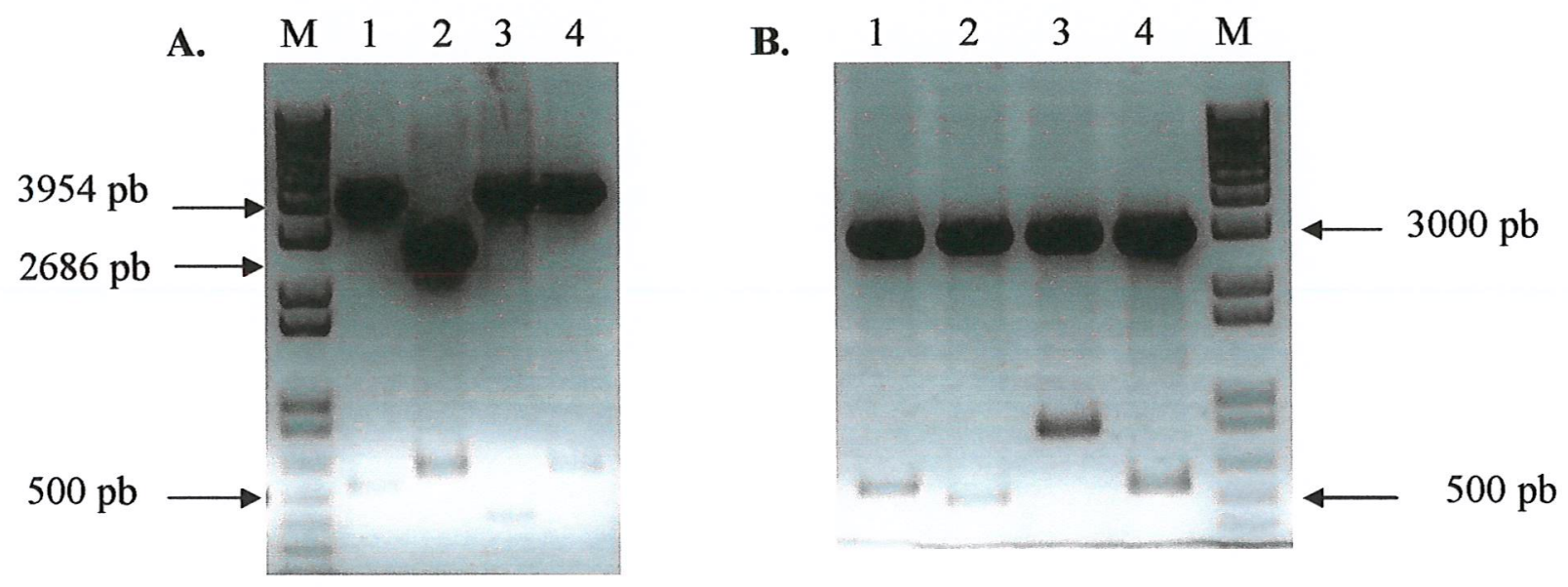

Figura 4 - Perfil de restrição dos plasmídios para confirmação da presença dos fragmentos 3' e 5'. A. Linhas 1 a 4: clones positivos para clonagem dos fragmentos 3' das ORFs Xf-818 (pSG1), Xf-1940 (pVF2), Xf-2359 (pSG12) e Xf-2708 (pSG21), respectivamente. B. Linhas 1 a 4: clones positivos para clonagem dos fragmentos 5' das ORFs Xf-818 (pSG2), Xf-1940 (pSG55), Xf-2359 (pSG11) e Xf-2708 (pSG22), respectivamente. As bandas de maior tamanho representam os vetores linearizados. $\mathbf{M}$ - marcador de massa molecular $1 \mathrm{~kb}$ plus DNA Ladder (Gibco BRL) 


\subsubsection{Clonagem dos fragmentos $3^{\prime}$ em vetor pEYFP-SK}

Os plasmídeos pSG1, pVF2, pSG12 e pSG21 digeridos com as enzimas BamHI e XhoI produziram os fragmentos $3^{\prime}$ (Figura 4A), que foram purificados do gel de agarose e clonados em vetor pEYFP-SK digerido com as enzimas BglII e XhoI. Os produtos destas ligações foram transformados em Escherichia coli e a confirmação das clonagens foram feitas pelas reações de restrição com as enzimas SstI e XhoI, para separação de fragmentos cujos tamanhos compreendam os fragmentos 3' fusionados ao gene yfp que possui 797 pb (Figuras 5).

Observando-se a Figura 5 confirmaram-se as clonagens, pois foram obtidos os fragmentos de $1.334 \mathrm{pb}$ (Xf-818), $1.221 \mathrm{pb}$ (Xf-2359), 1.403 pb (Xf-2708) e $1.400 \mathrm{pb}$ (Xf-1940), separados do restante do vetor de $3000 \mathrm{pb}$.

Foi confirmado então as construções pSG3, pSG13, pSG23 e pVF4 contendo respectivamente os fragmentos 3' das ORFs Xf-818, Xf-2359, Xf-2708 e Xf-1940 clonados em vetor pEYFP-SK. A representação destes plasmídeos está na Figura 6.

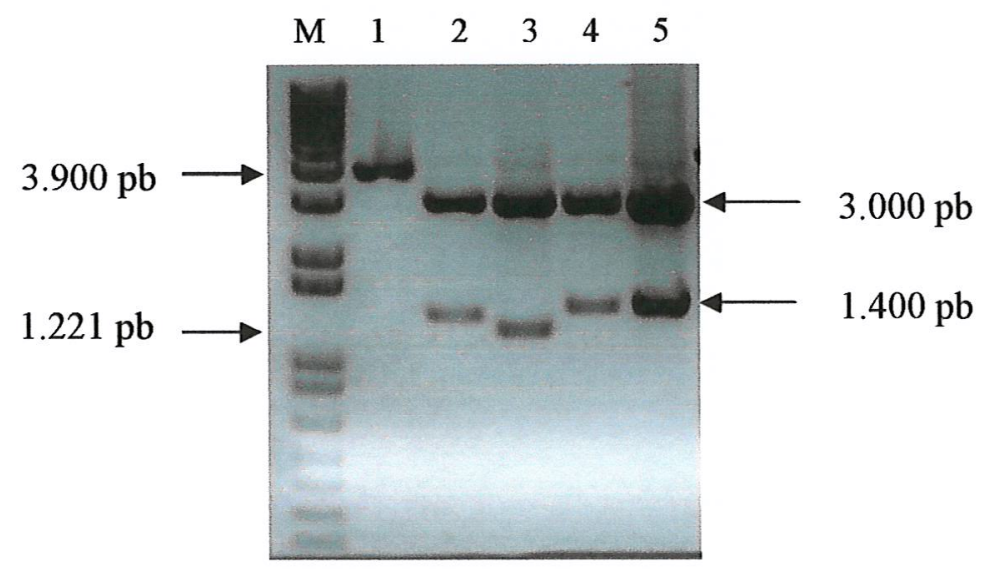

Figura 5 - Perfil de restrição dos plasmídios para a verificação da presença dos insertos. Linha 1: pEYFP linearizado com XhoI (3.900 pb). Linhas 2 a 5: plasmídios pSG3, pSG13, pSG23 e pVF4 digeridos com SstI e XhoI, confirmando a presença de bandas representando os fragmentos 3' fusionados ao gene yfp (1.334 pb, $1.221 \mathrm{pb}, 1.403 \mathrm{pb}$ e $1.400 \mathrm{pb}$, respectivamente) e o restante do vetor (3.000 pb). M- marcador de massa molecular $1 \mathrm{~kb}$ plus DNA Ladder 

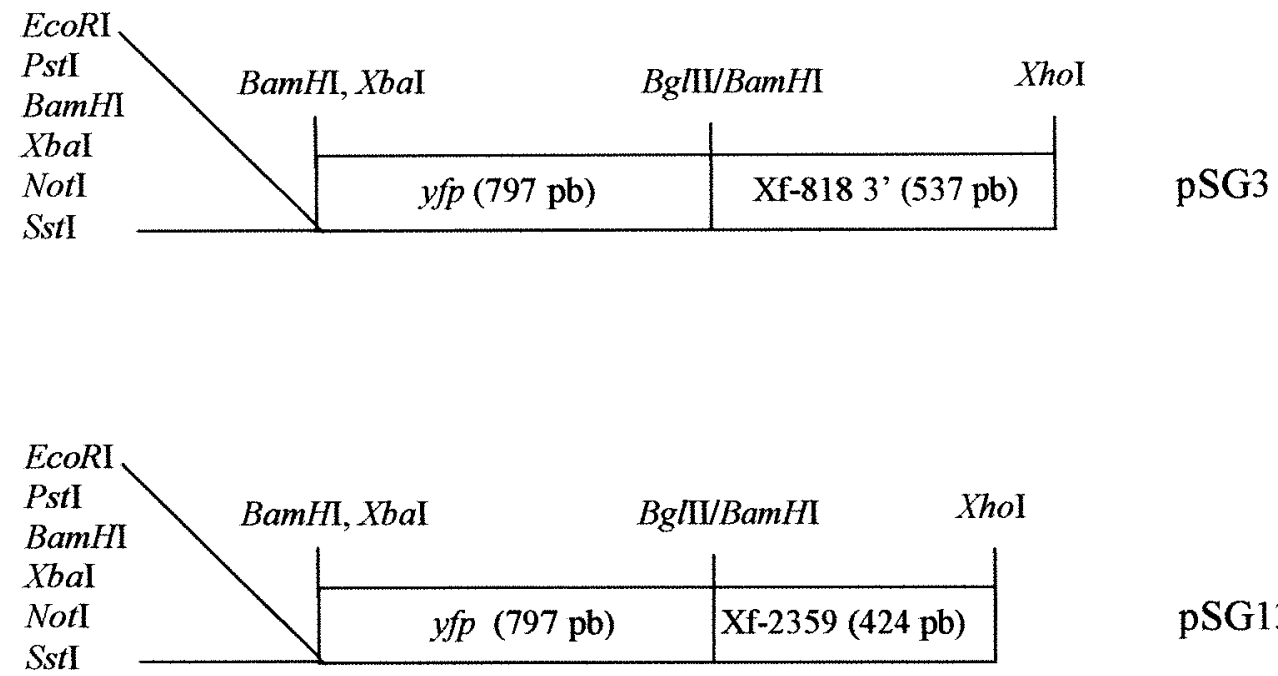

pSG13

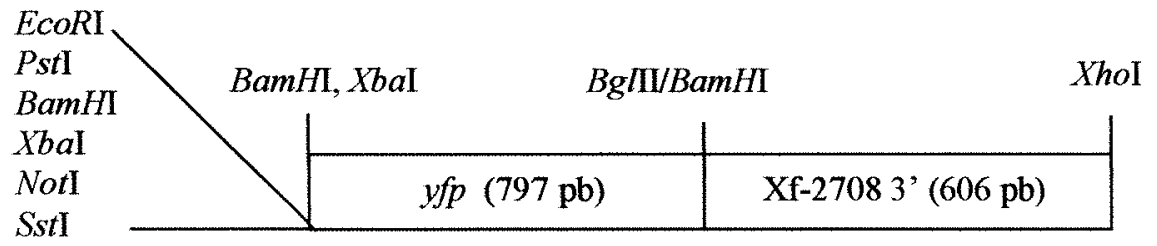

pSG23

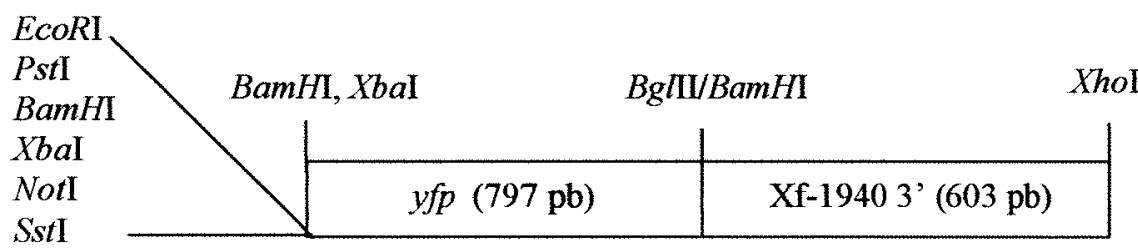

pVF4

Figura 6 - Esquemas representando os fragmentos 3' das ORFs fusionados ao gene yfp em vetor pEYFP resultando nos plasmídios pSG3, pSG13, pSG23 e pVF4 


\subsubsection{Clonagem dos fragmentos 5' nos vetores pSG3, pSG13, pSG23 e pVF4}

Após a construção dos plasmídios pSG3, pSG13, pSG23 e pVF4 fez-se a inserção dos fragmentos 5' nos sítios SstI e BamHI destes plasmídios, a partir dos plasmídeos pSG2, pSG55, pSG11 e pSG22 que foram digeridos com as enzimas SstI e $B g l$ III liberando os fragmentos $5^{\prime}$.

Analisando o perfil de restrição dos plasmídios produzidos por reações de restrição com as enzimas $S s t \mathrm{I}$ e XhoI (Figura 7), para separação de fragmentos cujos tamanhos correspondam ao gene $y f p$ flanqueado pelos fragmentos $5^{\prime}$ e 3 ' das ORF, as clonagens foram confirmadas, pois foram obtidas as bandas de $1.894 \mathrm{pb}$ (Xf-818), 2.040 pb (Xf-2359), 1.943 pb (Xf-2708) e 1.904 pb (Xf-1940), separadas do restante do vetor de $3.000 \mathrm{pb}$.

Confirmaram-se então as construções dos plasmídios pSG4, pSG14, pSG25 e pSG57 contendo o gene $y f p$ flanqueado, respectivamente, pelos fragmentos 5' e 3' das ORFs Xf-818, Xf-2359, Xf-2708 e Xf-1940, representados na Figura 8.

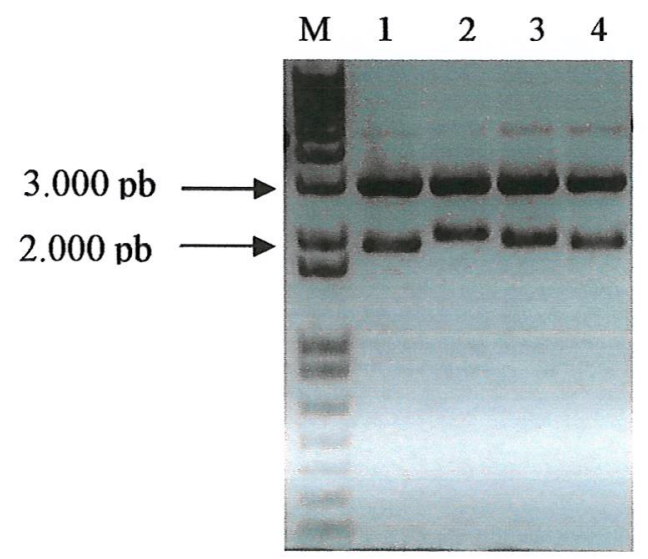

Figura 7 - Perfil de restrição dos plasmídios para a verificação da presença dos insertos. Linhas 1 a 4: plasmídios pSG4, pSG14, pSG25 e pSG57 digeridos com SstI e $X h o I$, confirmando a presença de bandas representando o gene $y f p$ flanqueado pelos fragmentos 5' e 3' das ORFs Xf-818 (1.894 pb), Xf-2359 (2.040 pb), Xf-2708 (1.943 pb) e Xf-1940 (1904 pb) e o restante do vetor (3.000 pb). M - marcador de massa molecular $1 \mathrm{~kb}$ plus DNA Ladder (Gibco BRL) 


\begin{tabular}{|c|c|c|}
\hline $\begin{array}{l}\text { SstI } \\
\text { BamHI }\end{array}$ & $\begin{array}{l}\text { BglIL/BamHI, } \\
\text { Xbal }\end{array}$ & BgIII/BamHI \\
\hline $\begin{array}{l}\text { ORF 818-5 } \\
(563 \mathrm{pb})\end{array}$ & $\begin{array}{c}y f p \\
(797 \mathrm{pb})\end{array}$ & $\begin{array}{c}\text { ORF 818-3 } \\
(537 \mathrm{pb})\end{array}$ \\
\hline
\end{tabular}

pSG4

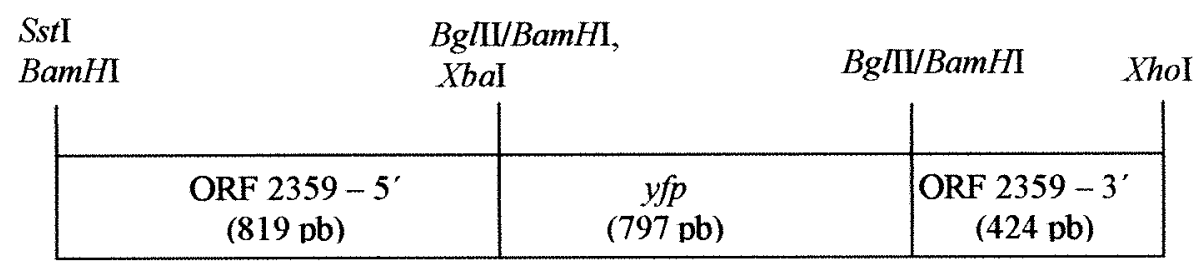

pSG14

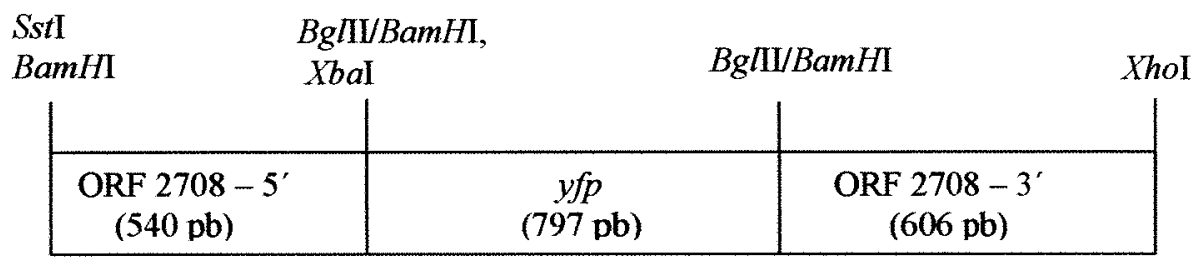

pSG25

SstI $\begin{aligned} & \text { BglII/BamHI, } \\
& \text { BamHI }\end{aligned}$
\begin{tabular}{|c|c|c|}
\hline $\begin{array}{c}\text { ORF } 1940-5^{\prime} \\
(504 \mathrm{pb})\end{array}$ & $\begin{array}{c}\text { yfp } \\
(797 \mathrm{pb})\end{array}$ & $\begin{array}{c}\text { ORF } 1940-3^{\prime} \\
(603 \mathrm{pb})\end{array}$ \\
\hline
\end{tabular}

pSG57

Figura 8 - Esquemas representando o gene $y f p$ flanqueado pelos fragmentos 5' e 3' das ORFs Xf-818, Xf-2359, Xf-2708 e Xf-1940 resultando, respectivamente, nos plasmídios pSG4, pSG14, pSG25 e pSG57 


\subsection{Construção dos vetores para disrupção das ORFs Xf-810 e Xf-1940 utilizando o cassete $l a c Z-\mathrm{Km}^{\mathrm{R}}$}

Para a obtenção de mutagênese das ORFs Xf-810 e Xf-1940 a partir da disrupção das mesmas com lacZ- $\mathrm{Km}^{\mathrm{R}}$, inicialmente foram feitos PCRs para a amplificação das ORFs, utilizando os iniciadores descritos na Tabela 2, a partir dos cosmídeos Xf-07H04 e Xf-03H12, respectivamente.

A construção do plasmídeo de disrupção da ORF Xf-810 foi iniciada a partir do plasmídio pNAW22 (Wulff, 2002) que apresenta um fragmento de 1.767 pb, compreendendo a ORF de $1.698 \mathrm{pb}$ e mais $69 \mathrm{pb}$ da região montante (upstream) à ORF, clonado no sítio SmaI do vetor pUC18.

Como a ORF Xf-810 possui dois sítios internos de restrição para a enzima $B g I I I$, o pNAW22 foi digerido com esta enzima, produzindo um fragmento de $1.068 \mathrm{pb}$ da ORF Xf-810 que foi descartado e substituído pelo cassete lacZ- $\mathrm{Km}^{\mathrm{R}}$ de $4,7 \mathrm{~kb}$, proveniente do plasmídeo pKOK6 digerido com BamHI, no vetor pUC18 resultando no plasmidio pSG30, que possui o cassete $l a c Z-\mathrm{Km}^{\mathrm{R}}$ flanqueado pelos segmentos $5^{\prime}$ e $3^{\prime}$ da ORF com 322 pb e 384 pb, respectivamente. A construção do pSG30 foi confirmada pela digestão com $P s t \mathrm{I}$ produzindo as bandas de tamanho esperado de $4,7 \mathrm{~kb}$ e $3.612 \mathrm{pb}$, e quando digerido com BamHI produziu o plasmídeo linearizado de 11.845 pb (Figuras $9 \mathrm{~A} \mathrm{e} 10)$.

Para a obtenção de vetor para disrupção da ORF Xf-1940 um fragmento de 1.152 pb foi amplificado a partir do cosmídio Xf-03H12, utilizando os primers Mrsa1243 e Mrsa2778 (Tabela 2) (Figura 9B). Este fragmento foi clonado no sítio SmaI em pUC18 obtendo-se o plasmídio pSG50 e confirmado pela digestão deste plasmídio com BamHI e $S s t$, observando-se a banda de $1.152 \mathrm{pb}$ referente ao fragmento contendo a ORF e $2.686 \mathrm{pb}$ do vetor (Figura 9C). Desde que a ORF Xf-1940 apresenta um sítio interno para a enzima Pst I que divide o fragmento de $1.152 \mathrm{pb}$ em duas partes com tamanho suficiente para ocorrência de evento de recombinação (633 e 519 pb), o pSG50 foi parcialmente digerido com Pst, pois o vetor pUC18 também apresenta um sítio de restrição para esta enzima, e no sítio $P s t \mathrm{I}$ interno à $\mathrm{ORF}$ foi inserido o cassete $l a c Z-\mathrm{Km}^{\mathrm{R}}$, 
isolado por digestão com esta mesma enzima a partir do pKOK6. O plasmídeo resultando foi denomidado de pSG51 (Figura 10). Na Figura 9C pode-se observar a confirmação da clonagem do cassete $l a c Z-\mathrm{Km}^{\mathrm{R}}$, após digestão do plasmídio com EcoRV, originando as bandas de 7.343 pb e 1.228 pb, confirmado que a ORF Xf-1940 e o cassete lacZ-Km ${ }^{\mathrm{R}}$ estão na mesma orientação.
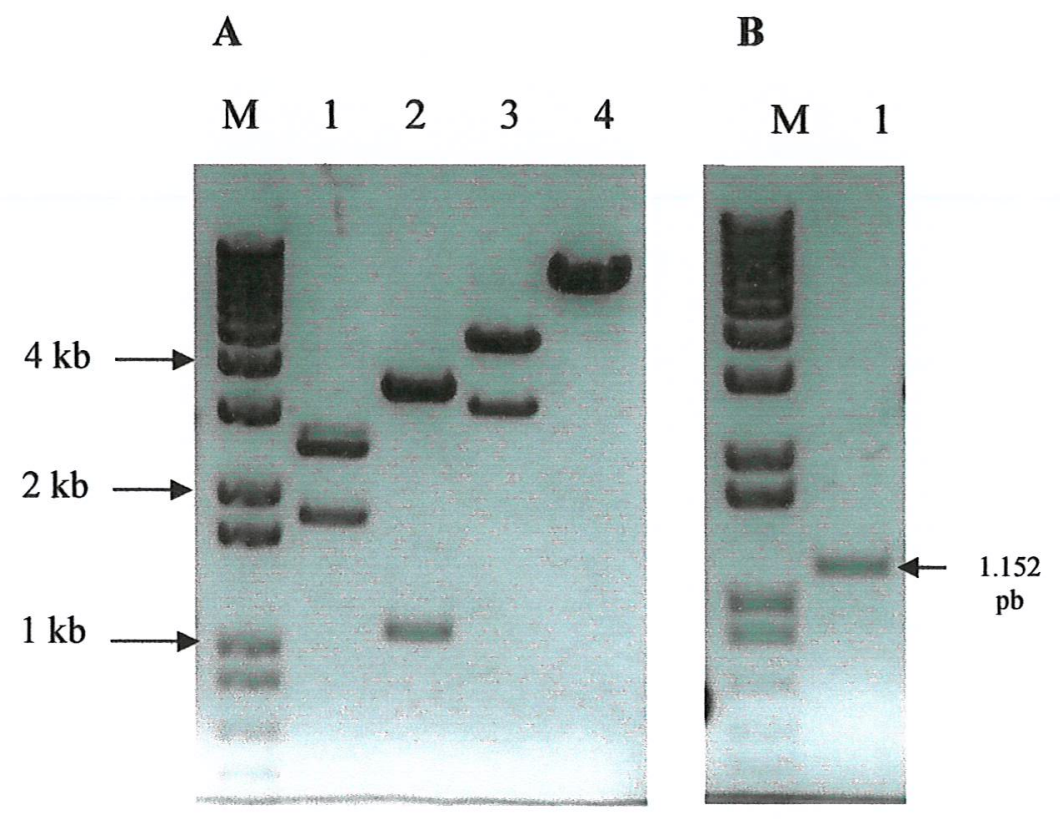

C

$12 \quad \mathrm{M}$

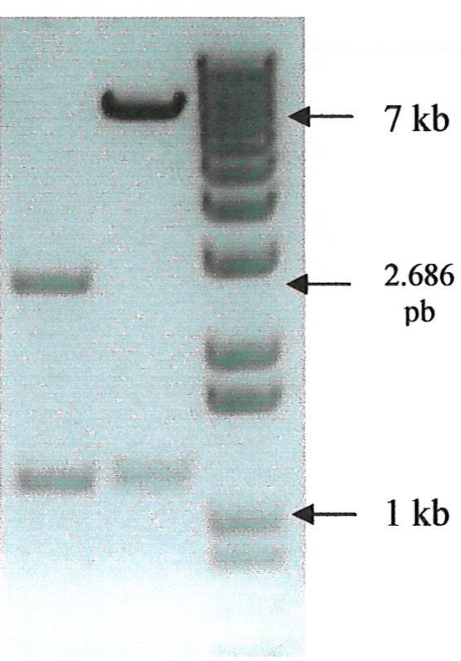

Figura 9 - Confirmação das construções para disrupção utilizando lacZ-Km ${ }^{\mathrm{R}}$. A. Linha 1: pNAW22 digerido com NdeI e HindIII; linha 2: pNAW22 digerido com BglII; linha 3: pSG30 digerido com PstI confirmando a clonagem do lacZ$\mathrm{Km}^{\mathrm{R}}$ (4,7 kb e $3.612 \mathrm{pb}$ do restante do vetor); linha 4: pSG30 digerido com BamHI (11845 pb). B. Linha 1: fragmento de $1.152 \mathrm{pb}$ contendo a ORF Xf1940 amplificada via PCR. C. Linha 1: digestão do pSG50 confirmando a presença do inserto de $1.152 \mathrm{pb}$ e do vetor de $2.686 \mathrm{pb}$; linha 2: pSG51 digerido com EcoRV confirmando que a ORF e o LacZ estão na mesma orientação (7.343 pb e 1.228 pb) 
A.

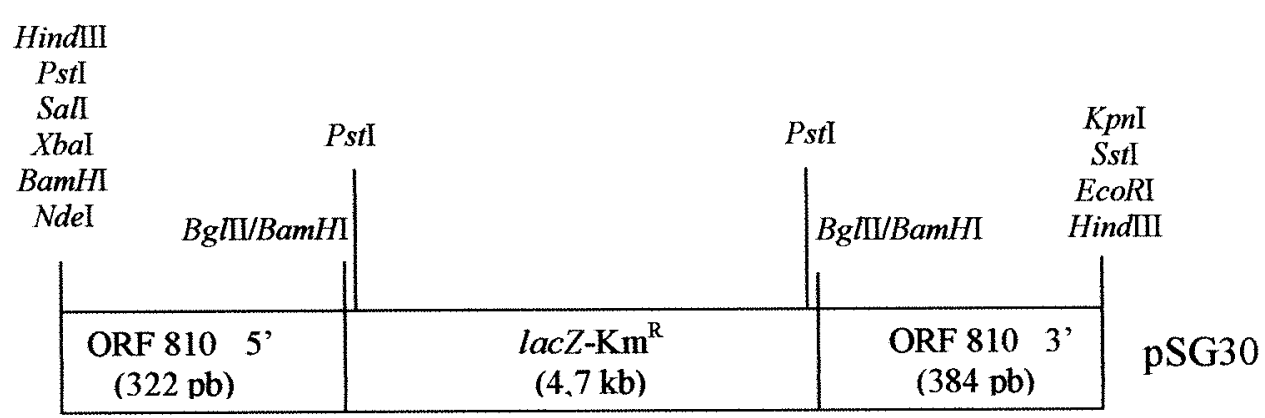

B.

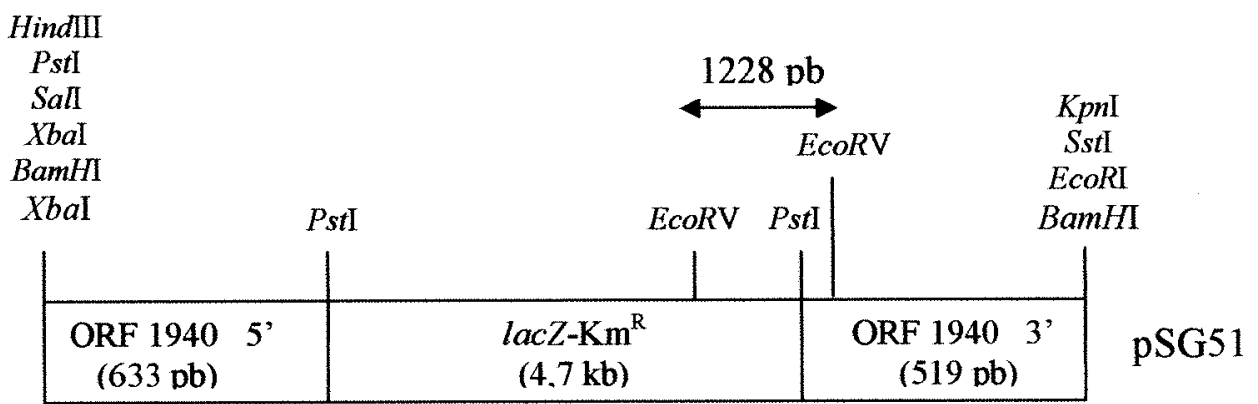

Figura 10 - Esquemas representando os plasmídeos pSG30 e pSG51.

A. Disrupção da ORF Xf-810 pelo cassete lacZ-Km ${ }^{\mathrm{R}}$ (pSG30)

B. Disrupção da ORF Xf-1940 pelo cassete lacZ-Km ${ }^{\mathrm{R}}$ (pSG51) 


\subsection{Clonagem da origem de replicação (OriC) de Xylella fastidiosa}

Para ser possível a replicação do plasmídeo transformado dentro da célula de $X$. fastidiosa-CVC é necessário a presença da origem de replicação nativa dessa bactéria, podendo ser tanto a origem de replicação cromossômica (Monteiro et al., 2001) ou uma origem de replicação plasmidial (Qin \& Hartung, 2001; Silva Neto et al., 2002). No presente trabalho optou-se por utilizar a origem de replicação cromossômica (OriC).

A OriC de 366 pb obtida após digestão do plasmídeo p16Kori (Monteiro et al., 2001b) com BamHI foi clonada nos plasmídeos pSG4, pSG14, pSG25, pSG30 e pSG57 linearizados com BamHI, resultando nos plasmídeos pSG5, pSG15, pSG26, pSG31 e pSG59, respectivamente, representados nas Figuras 13 e 14. A confirmação deste plasmídeos finais construídos está mostrada na Figura 12 onde a digestão com BamHI resultou nos fragmentos de 366 pb (OriC) e de 4.894 pb (pSG5), 5.040 (pSG15), 4.943 pb (pSG26), 11.845 pb (pSG31) e 4.904 pb (pSG59).

O pSG51 apresenta dois sítios de restrição para BamHI, então fez-se a digestão parcial deste plasmídeo para linearizá-lo (Figura 11). Como controle de tamanho linear, pSG51 foi digerido com SalI (8.571 pb, linha 3 - Figura 11). Os fragmentos lineares de $8.571 \mathrm{pb}$ das linhas $4,5,6,7$ e 8 (Figura 11) foram purificados do gel de agarose e usados para a clonagem da OriC com 366 pb obtido da digestão do plasmídeo p16Kori e da OriC de 1,9 kb obtida do p16KdAori, resultando nos plasmídeos pSG52 e pSG53, respectivamente, representados na Figura 14. Para a confirmação da clonagem, os plasmídeos finais foram digeridos novamente com BamHI confirmando a presença da OriC de 366 pb (pSG52) e 1,9 kb (pSG53) (Figura 12).

\subsection{Confirmação das construções finais por seqüenciamento}

O seqüenciamento de nucleotídeos dos plasmídeos pSG5, pSG15, pSG26 e pSG59 utilizando os primers "forward" (F) usados nas amplificações dos fragmentos 5' (Tabela 2) e separadamente o primer P1EY(G)FP (Tabela 3), para as construções 
contendo o gene $y f p$, confirmaram as construções como também confirmou que o ATG, que codifica para o códon de iniciação, do gene $y f p$ estava no mesmo quadro aberto de leitura com relação ao ATG das ORFs (Figura 15).

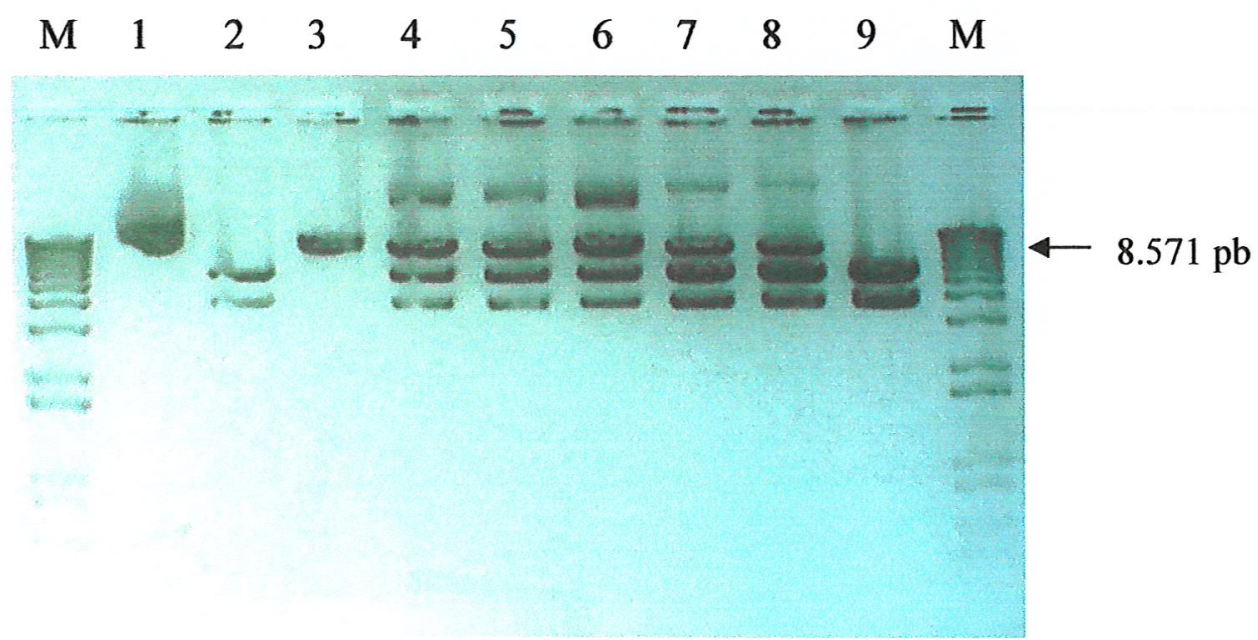

Figura 11 - Digestão parcial do pSG51. Linha 1: $2 \mu \mathrm{L}$ do pSG51 não digerido. Linha 2: pSG 51 digerido totalmente com BamHI. Linha 3: pS51 linearizado com SalI. Linhas 4 a 9: digestão parcial do pSG51 com BamHI a $37^{\circ} \mathrm{C}$ por $1,2,5,10$, 15 e 30 minutos respectivamente. $\mathrm{M}$ - marcador de massa molecular $1 \mathrm{~kb}$ plus DNA Ladder (Gibco BRL) 

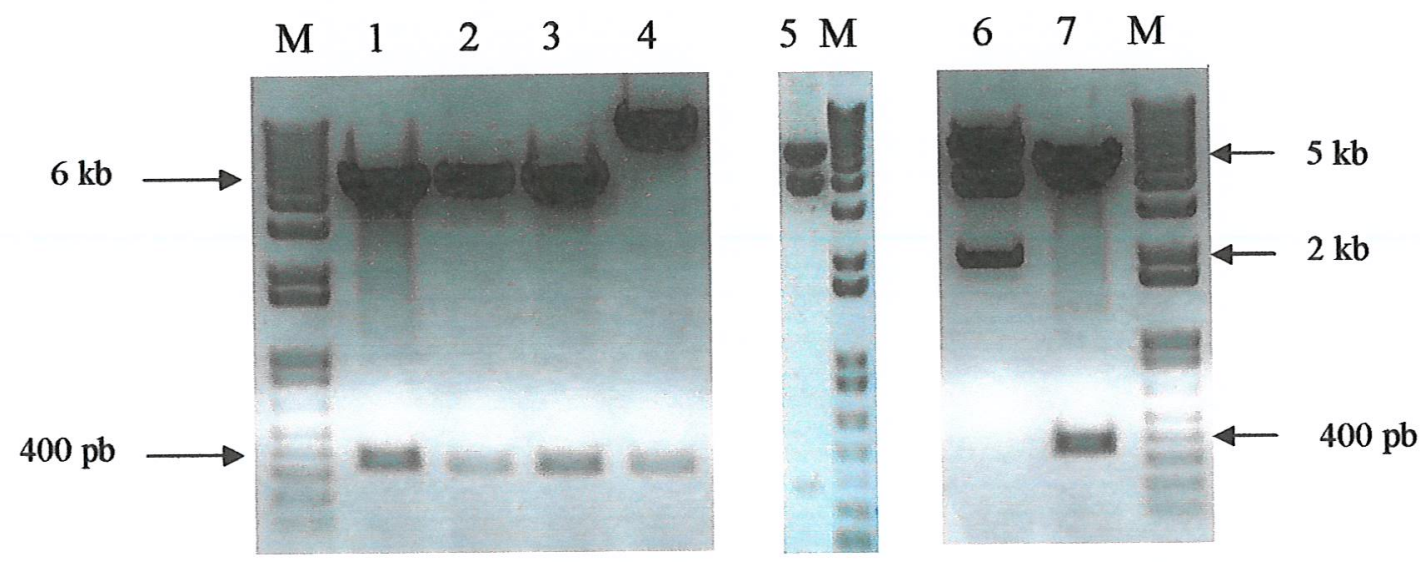

Figura 12 - Confirmação das clonagens da OriC. Linhas 1 a 7: digestão dos plasmídeos pSG5, pSG15, pSG26, pSG31, pSG52, pSG53 e pSG59 com BamHI confirmando a clonagem da OriC de 366 pb (pSG5, pSG15, pSG26, pSG31, pSG52 e pSG59) ou 1,9 kb (pSG53). M - marcador de massa molecular $1 \mathrm{~kb}$ plus DNA Ladder (Gibco BRL) 


\begin{tabular}{|c|c|c|c|}
\hline $\begin{array}{l}\text { SstI } \\
\text { BamHI }\end{array}$ & & & \\
\hline $\begin{array}{c}\text { OriC } \\
(366 \mathrm{pb})\end{array}$ & $\begin{array}{c}\text { ORF } 818-5 \\
(563 \mathrm{pb})\end{array}$ & $\begin{array}{c}y f p \\
(797 \mathrm{pb})\end{array}$ & $\begin{array}{c}\text { ORF } 818-3^{\prime} \\
(537 \mathrm{pb})\end{array}$ \\
\hline
\end{tabular}

\begin{tabular}{|c|c|c|c|}
\hline $\begin{array}{l}\text { Sst I } \\
\text { BamHI }\end{array}$ & & & $a m H I$ \\
\hline $\begin{array}{c}\text { OriC } \\
(366 \mathrm{pb})\end{array}$ & $\begin{array}{c}\text { ORF } 2359-5 \\
(819 \mathrm{pb})\end{array}$ & $\begin{array}{c}y f p \\
(797 \mathrm{pb})\end{array}$ & $\begin{array}{c}\text { ORF } 2359-3 \\
\quad(424 \mathrm{pb})\end{array}$ \\
\hline
\end{tabular}

pSG15

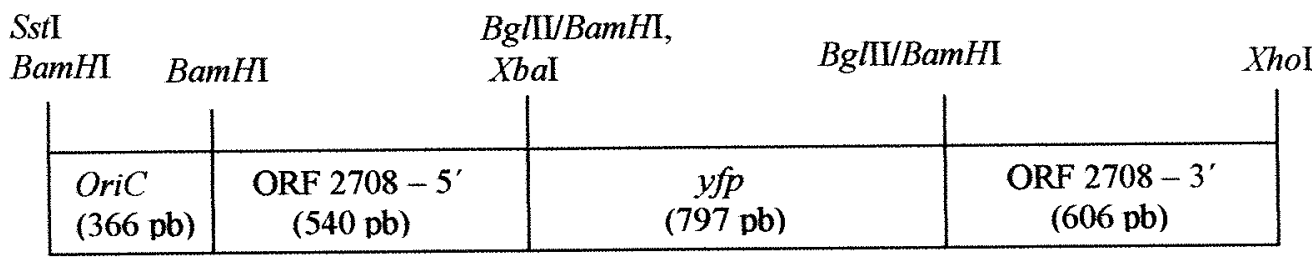

pSG26

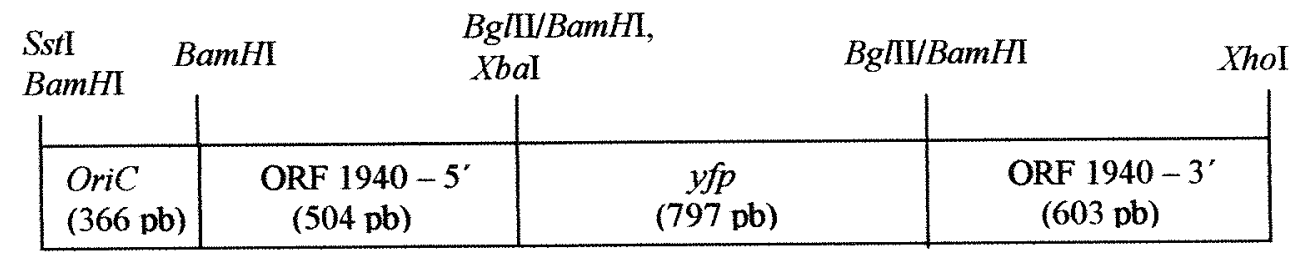

pSG59

Figura 13 - Esquemas representando as plasmídeos finais pSG5, pSG15, pSG26 e pSG57 para a disrupção ORFs Xf-818, Xf-2359, Xf-2708 e Xf-1940 com o gene $y f p$ 

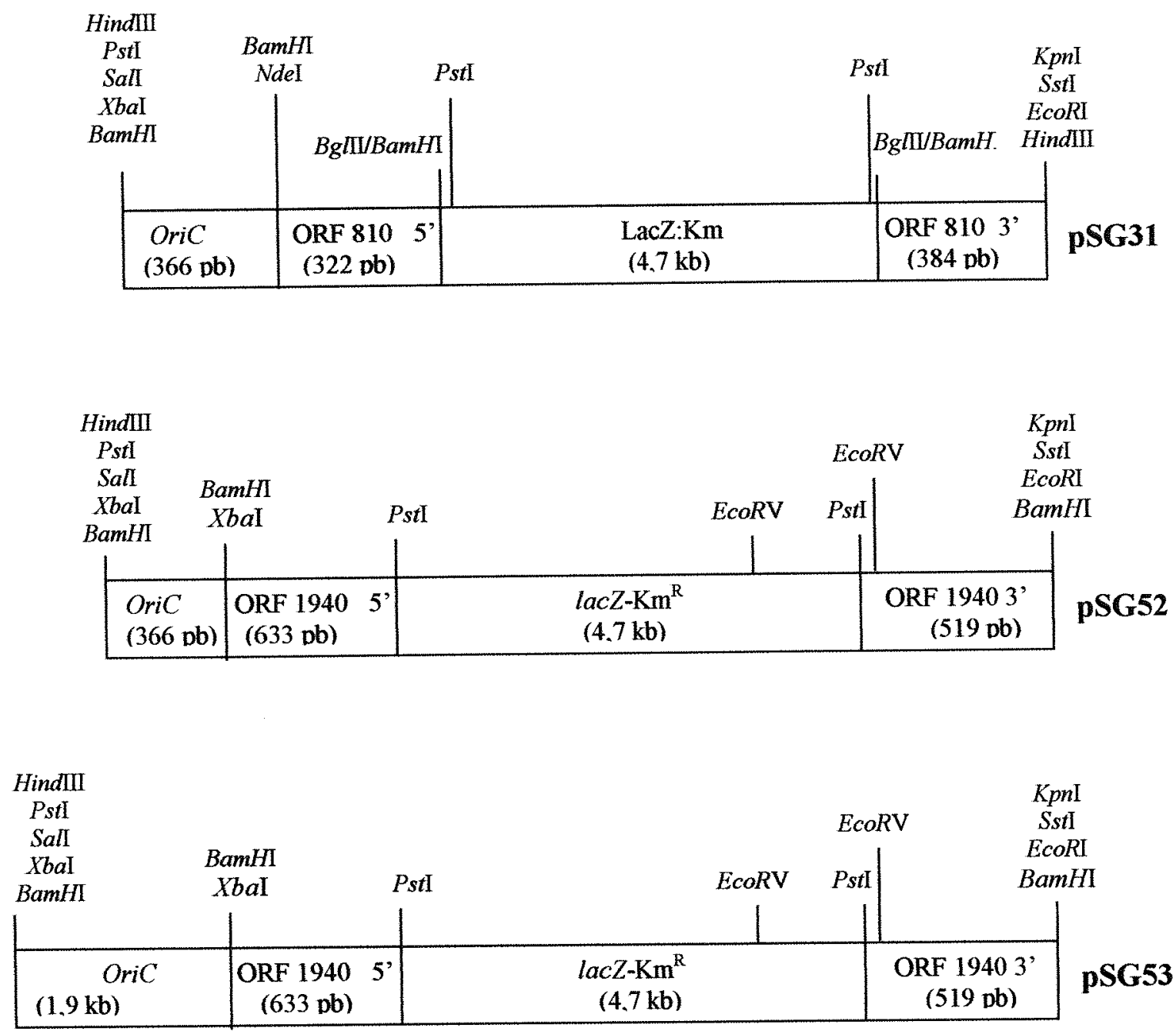

Figura 14 - Esquemas representando as plasmídeos finais pSG31, pSG52 e pSG53 para a disrupção ORFs Xf-810 e Xf-1940 com o cassete lacZ-Km ${ }^{\mathrm{R}}$ 
pSG5

Xf-818

$y f p$

ATGTCGTTTTCCAAACACTTCAGATCCTCTAGAATGGTGAG

pSG15

Xf-2359

$y f p$

ATGACCGAATCTCCACATCACAGATCCTCTAGAATGGTGAG

pSG26

$\mathrm{Xf}-2708$

$y f p$

ATGCCTATTTCCTTTCTATGCAGATCCTCTAGAATGGTGAG

pSG59

Xf-1940

$y f p$

ATGGTACTGACAATCGAAGCCAGATCCTCTAGAATGGTGAG

Figura 15 - Seqüência do quadro aberto de leitura dos plasmídeos pSG5, pSG15, pSG26 e pSG59. O ATG (códon de iniciação da tradução) das ORFs estão no mesmo quadro aberto de leitura com relação ao ATG do gene $y f p$, nos plasmídeos vetores de disrupção de $X$. fastidiosa. O primeiro ATG referese a ORF alvo; a seqüência AGATCC refere-se aos sítios Bglll/BamH onde as ORFs foram fusionadas; o segundo ATG refere-se ao gene $y f p$ 
4.6 Análise da expressão dos genes yfp e $l a c Z-\mathrm{Km}^{\mathrm{R}}$ das construções finais em $E$. coli

As bactérias E. coli contendo os plasmideos pSG5, pSG15, pSG26 e pSG59 apresentaram a expressão da proteína YFP (Yellow Fluorescent Protein), observada em microscópio de fluorescência. Desde que foi usado o mesmo filtro que é utilizado para a proteína GFP (Green Fluorescent Protein), ocorreu fluorescência verde, confirmando a expressão do gene $y f p$ nas construções preparadas para disrupção de $X$. fastidiosa. A Figura 16 A e B apresentam a expressão da YFP das bactérias transformadas com os plasmídeos pSG5 e pSG59, resultados semelhantes foram obtidos com os plasmídeos pSG15 e pSG26.

As bactérias $E$. coli contendo os plasmídeos pSG31, pSG52 e pSG53, que apresentam o cassete $l a c Z-\mathrm{Km}^{\mathrm{R}}$ cresceram em meio contendo canamicina e X-Gal/IPTG, confirmando-se a expressão desses genes pelo crescimento de colônias resistentes ao antibiótico canamicina e pela expressão do gene lacZ produzindo a enzima $\beta$ galactosidase, que age sobre o substrato $\mathrm{X}$-Gal produzindo um composto de cor azul. A Figura 17 A e B apresentam a expressão de bactérias $E$. coli transformadas com os plasmídeos pSG31 e pSG53, resultado semelhante foi obtido com o plasmídeo pSG52. 


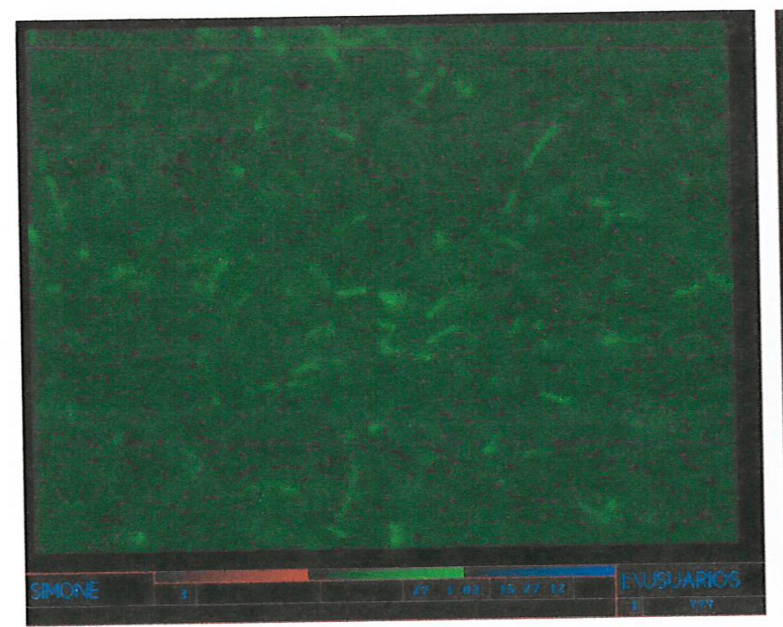

A

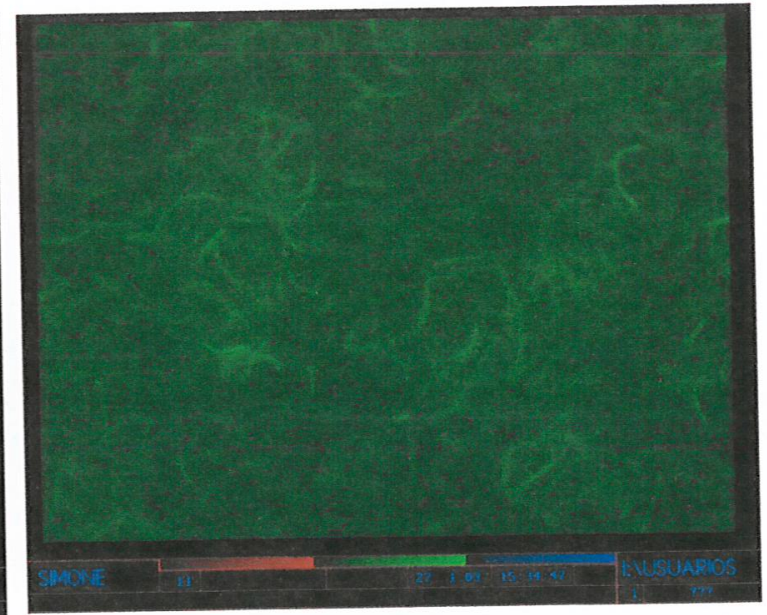

B

Figura 16 - Expressão do gene $y f p$ em microscópio de fluorescência. Bactérias contendo os plasmídeos pSG5 (A) e pSG59(B) fluorescendo (aumento de 1000x)

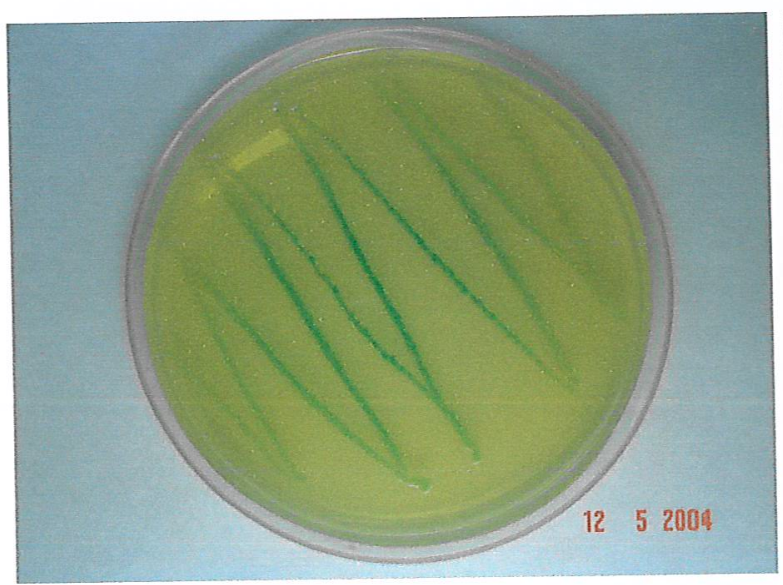

A

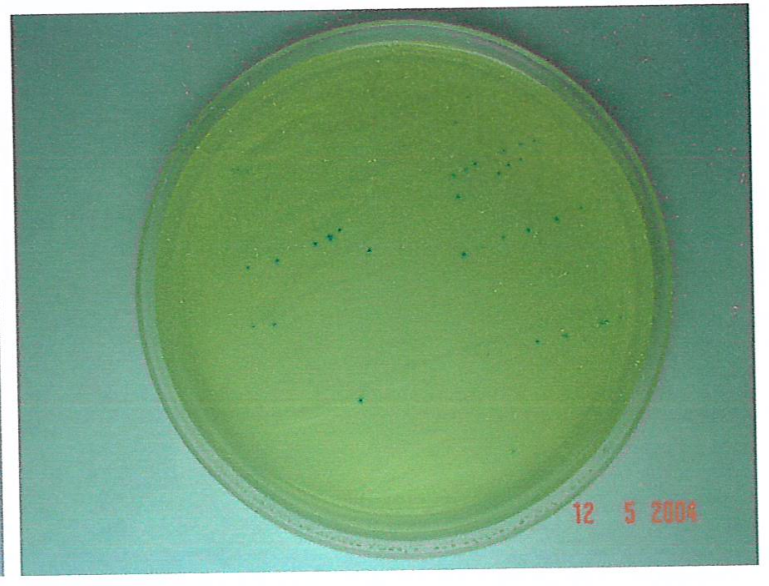

B

Figura 17 - Expressão do cassete lacZ-Km ${ }^{\mathrm{R}}$. Bactérias $E$. coli contendo os plasmídeos pSG31 (A) e pSG53 (B) que cresceram em meio LB contendo canamicina e produziram um precipitado de cor azul 


\subsection{Confirmação do isolado de $X$. fastidiosa e da obtenção de bactérias mutantes}

DNA genômico extraído de $X$. fastidiosa linhagem J1a12 cultivada de acordo com o item 3.9, confirmou-se tratar de Xylella fastidiosa, pois os primers CVC1 e CVC272int. utilizados amplificaram um fragmento de $500 \mathrm{pb}$, que é característico da linhagem causadora de CVC (Figura 18).

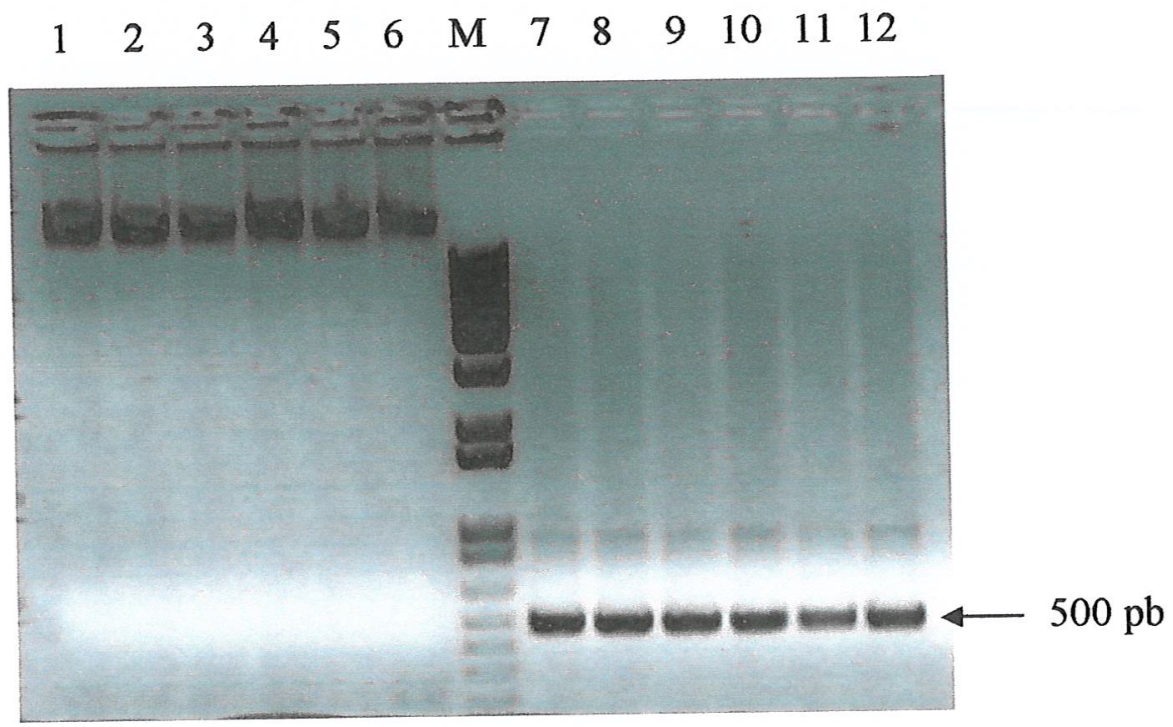

Figura 18 - DNA genômico e produto da amplificação do DNA de $X$. fastidiosa com primers CVC1 e CVC272int. Linhas 1 a 6: $2 \mu \mathrm{L}$ de DNA total de seis culturas de Xylella fastidiosa J1a12. Linhas 7 a 12: fragmentos de $500 \mathrm{pb}$ confirmando as culturas de $X$. fastidiosa. $\mathrm{M}$ - marcador de massa molecular $1 \mathrm{~kb}$ plus DNA Ladder (Gibco BRL) 
A obtenção de bactérias mutantes pela disrupção das ORFs Xf-818, Xf-1940, Xf2359 e Xf-2708 utilizando o gene $y f p$ foi realizada pela transformação via eletroporação com os plasmídeos vetores pSG5, pSG59, pSG15 e pSG26, respectivamente (item 3.10). Após 20 a 30 dias do evento de transformação as colônias de $X$. fastidiosa começaram a aparecer nas placas contendo meio PW sólido.

Nas transformações para a obtenção de bactérias mutantes através da inserção do cassete lacZ-Km ${ }^{\mathrm{R}}$ interrompendo as ORFs Xf-810 e Xf-1940 foram utilizados o plasmídeo pSG31 para a primeira e os plasmídeos pSG52 e pSG53 para a segunda. A diferença entre estes dois últimos plasmídeos é o tamanho da OriC, pSG52 apresenta a OriC de $366 \mathrm{pb}$ enquanto pSG53 apresenta a OriC inteira de aproximadamente 1,9 kb. Colônias de $X$. fastidiosa foram observadas depois de 20 a 30 dias de cultivo após a transformação e apresentaram coloração azul o que pode confirmar a expressão da proteína $\beta$-galactosidase.

A análise de obtenção dos transformantes foi realizada por reações de PCR. A amplificação de fragmentos de DNA de $X$. fastidiosa transformada com os plasmídeos pSG5, pSG15 e pSG26 foi feita utilizando o primer "forward" do fragmento 5' e o primer P1EY(G)FP, confirmando-se a presença dos fragmentos de $681 \mathrm{pb}, 933 \mathrm{pb}$ e 654, respectivamente (Tabela 4, Figura 19). Para bactérias transformadas com o plasmídeo pSG59 o PCR foi feito utilizando o primer "reverse" do fragmento 3' e o primer "forward" P2EY(G)FP, amplificando um fragmento de 637 pb (Tabela 4, Figura 19). Não ocorreu amplificação nos controles negativos (DNA de $X$. fastidiosa não transformada) (Figura 19). Estes resultados demonstram que estas bactérias apresentam as ORFs alvo interrompidas pelo gene $y f p$, conforme seus respectivos plasmídeos transformantes, mas não confirmava a integração do gene yfp no genoma da bactéria.

Para a confirmação da integração do gene yfp e do cassete lacZ- $\mathrm{Km}^{\mathrm{R}}$ no genoma da bactéria, foram utilizados um conjunto de primers sendo que um deles não se pareava no plasmídeo transformante, somente no genoma da bactéria, e o outro se pareava no gene yfp ou no cassete lacZ- $\mathrm{Km}^{\mathrm{R}}$ (Tabela 4). Após corrida em gel de agarose observouse os fragmentos de $900 \mathrm{pb}, 1.050 \mathrm{pb}, 700 \mathrm{pb}, 600 \mathrm{pb}, 600 \mathrm{pb}$ e $655 \mathrm{pb}$ para as culturas de $X$. fastidiosa transformadas com pSG5, pSG15, pSG31, pSG52, pSG53 e pSG59, 
respectivamente, e não ocorreu nenhuma amplificação nos controles negativos (DNA de $X$. fastidiosa não transformada) (Figura 20) e também não foi obtido resultado positivo para bactérias transformadas com pSG26 (dado não apresentado). Dessa maneira conclui-se que ocorreu a disrupção das ORFs Xf-818, Xf-2359 e Xf-1940 com o gene $y f p$, e das ORFs Xf-810 e Xf-1940 com o cassete lacZ-Km ${ }^{\mathrm{R}}$, ou seja, o método de transformação de Xylella fastidiosa utilizado foi eficiente.

Também foi observado que tanto a OriC de $366 \mathrm{pb}$ como a de 1,9 kb tornaram possíveis o evento de transformação de $X$. fastidiosa.

Tabela 4. Conjunto de primers utilizados para a confirmação da transformação de $X$. fastidiosa e os tamanhos de fragmentos esperados

\begin{tabular}{|c|c|c|}
\hline ORF & Primers & $\begin{array}{c}\text { Tamanho do } \\
\text { fragmento esperado } \\
\text { (pb) }\end{array}$ \\
\hline $\mathrm{Xf}-810$ & XF810R e KM Antisense & 700 \\
\hline \multirow[t]{2}{*}{ Xf-818 } & 4941B e P1EY(G)FP & 681 \\
\hline & XF818 e P1EY(G)FP & 900 \\
\hline \multirow[t]{2}{*}{$X f-2708$} & 2708P1SstIBamHI e P1EY(G)FP & 654 \\
\hline & $\mathrm{XF} 2708$ e P1EY(G)FP & 823 \\
\hline \multirow[t]{3}{*}{ Xf- 1940} & Mrsa-Xhol e P2EY(G)FP & 637 \\
\hline & XF1940 e P1EY(G)FP & 655 \\
\hline & Mrsa-Xhol e KM Antisense & 600 \\
\hline \multirow[t]{2}{*}{$\mathrm{Xf}-2359$} & PectatoP1SstIBamHI e PIEY(G)FP & 933 \\
\hline & XF2359 e P1EY(G)FP & 1.050 \\
\hline
\end{tabular}



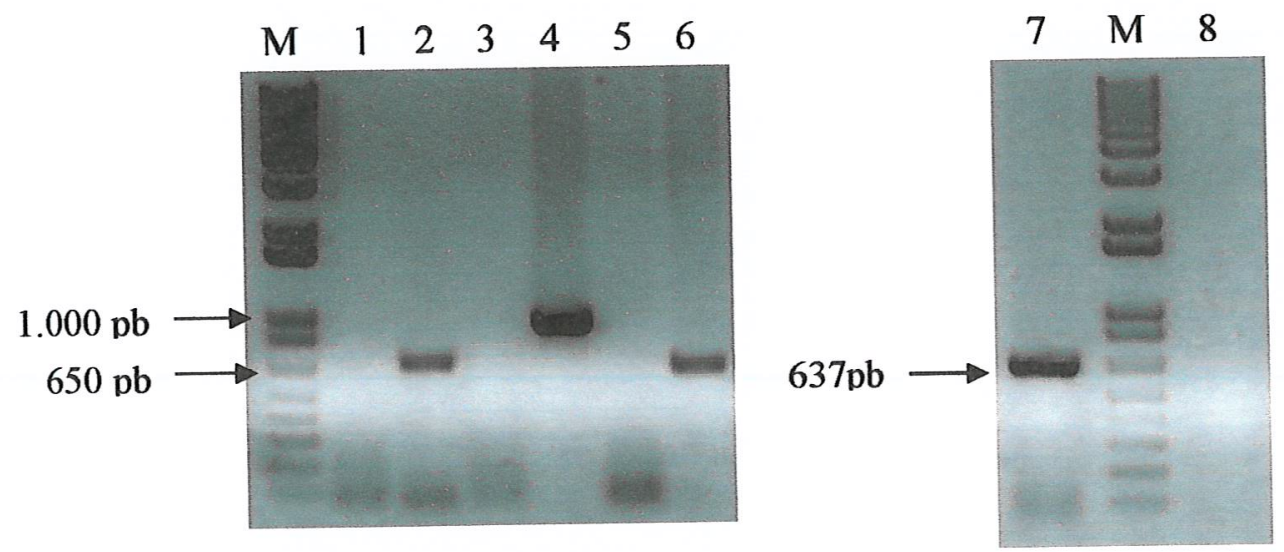

Figura 19 - Confirmação da presença das ORFs interrompidas pelo gene $y f p$ por PCR. Linhas $1,3,5$ e 8: DNA de $X$. fastidiosa não transformada utilizando os mesmos primers que para as transformações com os plasmídeos pSG5, pSG15, pSG26 e pSG59, respectivamente (controles negativos). Linha 2: $X$. fastidiosa transformada com pSG5 (681 pb). Linha 4: X. fastidiosa transformada com pSG15 (933 pb). Linha 6: $X$. fastidiosa transformada com pSG26 (654 pb). Linha 7: X. fastidiosa transformada com pSG59 (637 pb) 

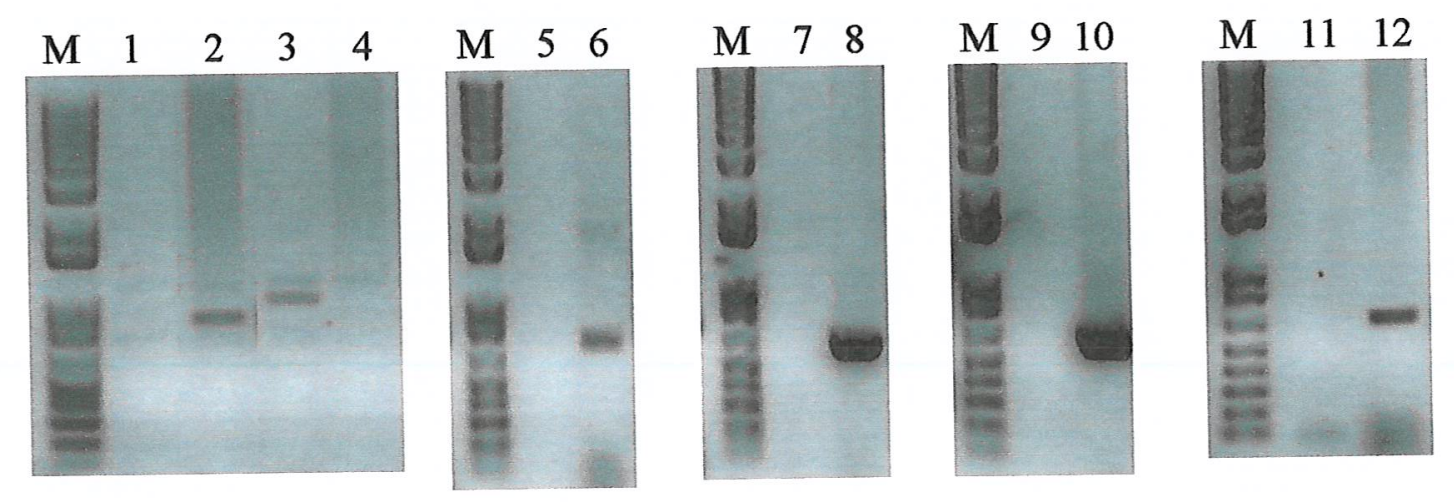

Figura 20 - Confirmação da disrupção das ORFs de $X$. fastidiosa. Linhas 1, 4, 5, 7, 9 e 11: PCR com DNA de $X$. fastidiosa não transformada utilizando os mesmos primers que para as transformações com os plasmídeos pSG5, pSG15, pSG31, pSG52, pSG53 e pSG59, respectivamente (controles negativos). Linha 2: $X$. fastidiosa transformada com pSG5 (900 pb). Linha $3: X$. fastidiosa transformada com pSG15 (1.050 pb). Linha 6: X. fastidiosa transformada com pSG31 (700 pb). Linha 8: $X$. fastidiosa transformada com pSG52 (600 pb). Linha 10: $X$. fastidiosa transformada com pSG53 (600 pb). Linha 12: $X$. fastidiosa transformada com pSG59 (655 pb) 


\section{DISCUSSÃO}

O seqüenciamento do genoma da $X$. fastidiosa por Simpson et al. (2000) identificou $2.904 \mathrm{ORFs}$, sendo que $47 \%$ apresentaram similaridade de seqüência com proteínas conhecidas já estudadas em outros organismos, entre estas ORFs, 147 apresentaram função biológica relacionada a genes de patogenicidade, virulência $\mathrm{e}$ adaptação do patógeno ao hospedeiro. Dois anos depois, o genoma de $X$ fastidiosa foi reanalisado por Bhattacharyya et al. (2002) e atualizou a anotação das ORFs, verificando 2.985 ORFs, das quais $58 \%$ apresentaram função biológica por similaridade de sequêencia. $O$ genoma de mais de 100 raças de bactérias está completamente seqüenciado. As ORFs representam $90 \%$ do cromossomo bacteriano, mas a função de 40 a $60 \%$ dos genes não é conhecida (Philippe et al., 2004). A confirmação da função biológica de uma ORF deve ser determinada experimentalmente e um método eficiente para isso, é pela obtenção de mutantes em que a ORF em estudo é interrompida e perde a sua função biológica.

A metodologia de disrupção gênica é amplamente utilizada em estudos de genes relacionados a patogenicidade de microrganismos e vem contribuindo marcantemente para a identificação da função de genes (Donovan et al., 2001; Huang et al., 2000; Provence \& Curtiss, 1992). Esta metodologia é feita através da recombinação homóloga com conseqüente inativação do gene em estudo, substituindo-o por cassetes de expressão gênica como por exemplo, o lacZ-Km ${ }^{\mathrm{R}}$ (Kokotek \& Lotz, 1989) e também por genes repórteres como gfp e $y f p$ que codificam para proteínas fluorescentes, verde e amarelada, respectivamente (Shen et al., 2003; Adaikkalam \& Swarup, 2002). A 
introdução de gene repórter no lugar do gene de interesse é preferencial, pois assim torna-se possível à monitoração "in situ" da expressão pelo promotor endógeno do gene.

A utilização de genes marcadores, que codificam para proteínas fluorescentes, apresentam muitas vantagens, pois podem ser detectadas "in situ" em células isoladas, mesmo que localizadas em sistemas complexos, usando microscópio de fluorescência (Normander et al., 1999) e a fluorescência é independente da presença de substrato, apesar de que para a expressão adequada da proteína é necessário a presença de oxigênio (Heim et al., 1994).

Griesbeck et al. (2001) obtiveram a expressão do gene yfp em E. coli e Miller et al. (2000) observaram a expressão deste gene em $E$. coli e também em outra bactéria gram-negativa, a Campylobacter jejuni que é parasita de animais. Já Stuurman et al. (2000) visualizaram a expressão da yfp em Rhizobium leguminosarum biovar trifolii. Vários outros estudos foram realizados utilizando a expressão do gene yfp como, por exemplo, em neurônios de rato (Narayan \& Greif, 2004), em células de humanos (Kretzschmar et al., 2004, Sorkina et al., 2003), em células de plantas como de Arabidopsis thaliana (Boisnard-Lorig et al., 2001, Van-Bruaene et al., 2003, Kiegle et al., 2000) e em células de epiderme de cebola (Duque \& Chua, 2003), confirmando que o gene $y f p$ apresenta-se muito útil para estudos de expressão gênica em diferentes organismos.

Neste trabalho foram construídos vetores de disrupção das ORFs de $X$. fastidiosa Xf-810, Xf-818, Xf-1940, Xf-2359 e Xf-2708. As ORFs Xf-818, Xf-2708, Xf-2359 e Xf-1940 foram interrompidas pela substituição utilizando o gene de fluorescência $y f p$, e as ORFs Xf-810 e, novamente, a Xf-1940 foram interrompidas com o cassete lacZ-Km ${ }^{\mathrm{R}}$.

Estas ORFs foram selecionadas pois possuem similaridade de seqüência com proteínas relacionadas a patogenicidade de microorganismos (Simpson et al., 2000; Bhattacharyya et al., 2002). A ORF Xf-1940 apresenta similaridade com a proteína MsrA (metionina sulfoxido redutase) que se mostrou importante no processo de manutenção da adesão da bactéria $X$. fastidiosa (Leite et al., 2002). As Orfs Xf-810 e Xf818 apresentam similaridade de $3 \mathrm{e}^{-50}$ e $1 \mathrm{e}^{-145}$, respectivamente, com endoglicanase, que é uma celulase com mecanismo endoglicolítico de ataque às moléculas de celulose, de 
Xanthomonas campestris pv. campestris (Gough et al., 1990). A ORF Xf-2708 também apresenta função de endoglicanase com similaridade de seqüência de $2 \mathrm{e}^{-85}$ com uma endoglicanase de Ralstonia solanacearum (http://aeg.lbi.ic.unicamp.br/xf/; Wulff et al., 2003). A atividade celulásica desses genes de $X$. fastidiosa foi confirmada clonando-os em vetores de expressão e as respectivas proteínas foram produzidas em $E$. coli, e após ensaios enzimáticos foram caracterizadas como endoglicanases (Wulff, 2002), e também foi observada a expressão da ORF Xf-818 em bactérias $X$. fastidiosa crecendo em meio PW (Scarpari, 2001), confirmando a função biológica a elas atribuídas pela anotação das ORFs.

Para obter sucesso no ataque da célula hospedeira, o patógeno tem que passar pela barreira externa da célula, que em plantas é a parede celular que é composta principalmente pelos polissacarídeos celulose, hemicelulose e pectina. Celulose representa o principal constituinte dos polissacarídeos da parede celular e consiste de polímeros lineares de resíduos de glicose. Os polímeros de celulose estão presentes em estruturas ordenadas (fibras), e a sua principal função é conferir rigidez à parede celular vegetal (Vries \& Visser, 2001). A pectina é outra substância importante presente na parede celular primária e na lamela média de vegetais, mantendo a integridade estrutural das paredes de células de plantas superiores (Carpita \& Gibeaut, 1993).

Celulases são essenciais para a reciclagem da celulose, considerado o polímero mais abundante já encontrado até hoje. Devido o seu potencial uso na indústria (Bhat, 2000) e o seu proeminente papel como fator de patogenicidade, as celulases são focos de numerosos estudos bioquímicos e fisiológicos (Ahn et al., 2001; Vries \& Visser, 2001; Wilson, 2004; Bera-Maillet et al., 2004). A pectato liase também é importante na degradação da parede celular, pois esta enzima quebra a pectina localizada na lamela média e na parede celular primária levando a maceração do tecido da planta (Lietzke et al., 1994), sendo esta degradação da pectina uma característica de muitas bactérias associadas a plantas, especialmente fitopatógenos (Bekri et al., 1999). As celulases juntamente com pectato liase são enzimas importantes que são utilizadas por patógenos para a obtenção de energia e também como um mecanismo de patogenicidade na 
colonização do tecido vegetal (Nunes et al. 2003; Dow \& Daniels, 2000; Lambais et al., 2000).

Enzimas extracelulares que degradam a pectina, comprovadamente contribuem para o desenvolvimento de sintomas em doenças de podridão de raiz e pode induzir resposta de defesa em um grande número de plantas (Walton, 1994). A maior barreira para uma definição mais precisa do papel da degradação da pectina no processo da doença é a presença na maioria dos microorganismos, de múltiplos genes que codificam enzimas que degradam a pectina. Para comprovar a importância da pectato liase na virulência de Nectria hematococca foi necessário a disrupção, simultaneamente, dos dois genes que codificam pectato liases presentes no microoganismo (Rogers et al., 2000). No genoma da $X$. fasidiosa não foi identificado à presença de nenhuma ORF classificada como pectato liase, mas a ORF Xf-2359 com 236 aminoácidos, apresentou similaridade $\left(1 \mathrm{e}^{-10}\right)$ com a pectato liase de Pseudomonas viridiflava (Liao et al., 1988), a qual possui 896 aminoácidos. Esta diferença acentuada de tamanho pode acarretar na ausência de função desta ORF ou pode apresentar outra função biológica, pois $X$. fastidiosa não precisa de mecanismos para invadir a planta já que ela é depositada no xilema por insetos (Keen et al., 2000). Alves (2003) através de observações utilizando microscópio eletrônico de transmissão e varredura e imunomarcação para componentes da parede celular, observaram fortes evidências de que $X$. fastidiosa é capaz de degradar a parede celular primária das pontuações dos vasos do xilema de citros e migrar para os vasos adjacentes, assim, se a ORF Xf-2359 não codificar uma pectato liase, restará uma dúvida sobre como a bactéria passa de um vaso para outro do xilema sem precisar degradar a pectina presente na parede celular primária e na lamela média. Em adição a esta observação também não foi detectada a expressão de um suposto precursor de poligalacturonase (Xf-2466) (Simpson et al., 2000) em culturas de X. fastidiosa, crescendo em meio PW sob condições de baixa e alta densidade celular (Scarpari, 2001).

Dessa maneira, a importância do estudo funcional das endoglicanases Xf-810, $\mathrm{Xf}-818, \mathrm{Xf}-2708$ e da suposta pectato liase Xf-2359 se deve ao fato de que um mecanismo patogênico importante envolve a degradação da parede celular vegetal por 
uma bateria de enzimas secretadas por fitopatógenos, que degradam a celulose e a matriz de pectina por adição de água, quebrando as ligações glicosídicas (Herron et al., 2000).

Muitos genes relacionados com a produção de exoenzimas em bactérias gramnegativas foram estudados utilizando-se da tecnologia de disrupção gênica. Em Xanthomonas campestris pv. campestris, sete fatores relacionados com a patogenicidade necessários para a produção de pectato liases, proteases, endoglicanase, amilase e goma xantana foram identificados por esta tecnologia (Tang et al., 1991).

Com a disrupção de celulases foi observada a importância dessas enzimas na patogenicidade de muitos microorganismos como, Erwinia carotovora subsp. carotovora (Mae et al., 1995), Claviceps purpurea (Muller et al. 1997), Clavibacter michiganensis subsp. michiganensis (Jahr et al., 2000) e Clavibacter michiganensis subsp. sepedonicus (Laine et al., 2000), sendo que nesses dois últimos microoganismos endoglicanases foram essenciais para o desenvolvimento de sintomas nos hospedeiros. Mutante de Pseudomonas solanacearum deficiente na produção de celulase (egl) mostrou-se menos virulento após inoculação em plantas de tomate (Roberts et al., 1988). A endoglicanase EngXCA de Xanthomonas campestris pv. campestris é importante nos primeiros estágios da patogenicidade em nabo e rabanete. Quando essas plantas eram inoculadas com os mutantes os sintomas demoraram um dia a mais para surgirem (Gough et al., 1988; Gough et al., 1990).

Pectato liases de fitopatógenos também foram inativados por disrupção e essas mutações foram importantes para a confirmação da importância dessa enzima na virulência do fungo patogênico de planta Nectria hematococca (Rogers et al., 2000) e de Colletotrichum gloeosporioides em planta de abacateiro (Yakoby et al., 2001), mas não mostrou-se essencial na patogenicidade de Glomerella cingulata (Bowen et al., 1995). A produção de pectato liase pela bactéria Xanthomonas campestris possui relação direta com o desenvolvimento dos sintomas de podridão em tubérculos de batata e em pimentão (Liao et al., 1996).

Uma característica comum entre enzimas extracelulares degradadoras produzidas por microorganismos é a redundância, ou seja, muitos microorganismos apresentam duas ou mais proteínas que possuem atividade enzimática iguais ou similar (Görlach et 
al., 1998), ou seja, a disrupção de um gene pode ser compensada por outras enzimas com atividades similares, e assim, individualmente, enzimas que degradam a parede celular podem não ser cruciais para patogenicidade de microorganismos, e uma bateria de tais enzimas certamente contribui para o desenvolvimento de muitas doenças de plantas (Sexton et al., 2000). A disrupção de apenas um gene em X. fastidiosa e a observação de que nesse mutante não ocorreu diminuição de patogenicidade pode levar a uma interpretação errada de que aquele gene não é importante para virulência da bactéria, por outro lado o gene pode ser essencial e apenas a distupção dele possa ser suficiente para alterar o nível de patogenicidade da bactéria, essas dúvidas só serão esclarecidas experimentalmente através da disrupção de cada gene, e se possível todos eles simultaneamente, e a análise de patogenicidade da bactéria após inoculação em plantas de citros ou em plantas hospedeiras alternativas como tabaco (Lopes et al, 2000; Alves et al., 2003) ou vinca (Monteiro et al., 2001a).

Além das enzimas degradadoras da parede celular, a aderência do patôgeno bacteriano às células eucarióticas é um passo crítico para a colonização e o sucesso da infeç̧ão (Finlay \& Falkow, 1997). A proteína metionina sulfoxide redutase é codificada pelo gene $m s r A$ tendo sido encontrada em uma variedade de organismos e tecidos animais (Kuschel et al., 1999; Brot et al., 1981; Moskovitz et al., 1996). Esta proteína é bastante estudada devido apresentar importante papel antioxidante nas células (Lowther et al., 2000; Douglas el al., 2004; Yermolaieva et al., 2004), e por apresentar papel importante na adesão de microorganismos (Leite et al., 2002; Wizemann et al., 1996). A ORF Xf-1940 de $X$. fastidiosa apresenta similaridade de sequêencia de $2 \mathrm{e}^{-67}$ com $m s r A$ de Synechocystis sp. e de $1 \mathrm{e}^{-60}$ com msrA de Escherichia coli (http://aeg.lbi.ic.unicamp.br/xf/).

A disrupção do gene que codifica a MsrA em muitos patógenos bacterianos responsáveis por infecções em humanos resultou na perda da habilidade de colonizar células hospedeiras (Taylor et al., 2003), sendo comprovado o envolvimento dessa proteína na virulência de microorganismos patógenos de humanos como Escherichia coli (Moskovitz et al., 1995; John et al., 2001; Wizemann et al., 1996), Streptococcus pneumoniae, Neisseria gonorrhoeae (Wizemann et al., 1996), Mycoplasma genitalium 
(Dhandayuthapani et al., 2001), em células de leveduras (Moskovitz et al., 1998) e também foi demonstrado ser um fator de virulência para o patógeno de planta Erwinia chrysanthemi (Hassouni et al., 1999).

Xylella fastidiosa possui as cigarrinhas como importante vetor de disseminação da doença entre plantas, e devido à alta velocidade e pressão com que a seiva do xilema passa pelas peças bucais e trato intestinal desses vetores, a adesão da bactéria é essencial para a colonização no inseto (Simpson et al., 2000). Assim a inoculação de $X$. fastidiosa mutante para a produção da proteína MsrA nos insetos vetores será importante para avaliar se esta proteína participa neste processo. Também, esta proteína está envolvida no processo de aderência e formação de agregados nos vasos do xilema, que levam aos sintomas da CVC (Leite et al., 2002).

Eventos de transformação e mutagênese por recombinação homóloga na linhagem de $X$. fastidiosa de citros mostrou-se ser menos eficiente quando comparado com linhagens de $X$. fastidiosa-PD, que apresentaram facilmente recombinação homóloga por troca alélica (Feil et al., 2003). Por razões ainda não estabelecidas, a transformação de $X$. fastidiosa parece ser dependente da linhagem da bactéria utilizada, sendo que até o momento não foi possível a transformação das linhagens 9a5c, PR1111 e AR1111 que causam doença em citros e das linhagens CA1111 e CA3124 que causam doença em café, sendo possivel apenas a transformação das linhagens de citros J1a12 e B111(Monteiro et al., 2001b). Possivelmente, a presença de barreiras funcionais de restrição que degradam DNA exógeno, evidenciado pela presença no genoma da bactéria, de quatro endonucleases de restrição (Simpson et al., 2000) e a dificuldade do cultivo desta bactéria, poderia contribuir para dificultar o evento de transformação.

Para testar a presença de transformantes de $X$. fastidiosa linhagem J1a12 deste presente trabalho, aliquotas das culturas transformadas foram analisadas por PCR com primers especificos, confirmando a presença de $X$. fastidiosa mutantes contendo as ORFs Xf-818, Xf-2359 e Xf-1940 substituídas pelo gene $y f p$ e as ORFs Xf-810 e Xf1940 interrompidas pelo cassete $l a c Z-\mathrm{Km}^{\mathrm{R}}$, confirmando a eficiência do método utilizado. O evento de recombinação homóloga com duas permutas foi possível, 
demonstrando que o tamanho dos fragmentos $5^{\prime}$, entre 322 e $819 \mathrm{pb}$, e dos fragmentos 3', entre 384 e 606 pb, são suficientes para a ocorrência de recombinação homóloga.

No trabalho de Monteiro et al. (2001b) foram obtidos a transformação de $X$. fastidiosa-CVC utilizando uma parte da OriC de 366 pb e também a OriC inteira de 1,9 $\mathrm{kb}$ oriundas da mesma bactéria, mas não obteve-se transformação quando utilizado plasmídeo vetor sem a OriC. No presente trabalho foi obtido a disrupção das ORFs utilizando tanto a OriC de $366 \mathrm{pb}$, que devido ao pequeno tamanho foi mais fácil de clonar nos plasmídeos vetores, como também com a OriC de $1,9 \mathrm{~kb}$, corroborando os resultados obtidos por Monteiro et al. (2001b).

Até o momento não foi obtido resultado positivo por PCR da disrupção da ORF $\mathrm{Xf}-2708$, pela integração do gene $y f p$, quando se utilizou primer específico cuja seqüência está presente no genoma de $X$. fastidiosa e ausente no plasmídeo vetor, mas quando utilizou-se primers internos ao plasmídeo vetor, o gene $y f p$ estava presente. É possivel ter ocorrido algum problema na escolha deste primer especifico.

A disrupção por recombinação homóloga com uma permuta já foi obtida para $X$. fastidiosa causadora da CVC (Silva Neto et al. 2002; Gaurivaud et al. 2002; Souza, 2002) e com duas permutas, como no caso deste trabalho, apenas um artigo foi publicado utilizando a linhagem J1a12 (Gaurivaud et al., 2002), e Sousa (2002) tentou, mas não obteve mutantes de $X$. fastidiosa J1a12 por troca alélica, demonstrado a dificuldade da ocorrência desse tipo de recombinação homóloga.

Mutantes de $X$. fastidiosa expressando o gene lacZ e o $\mathrm{Kam}^{R}$ usados para interromper as ORFs Xf-810 e Xf-1940 foram inoculados em meio PW líquido contendo o antibiótico canamicina. Após novas análises de PCR e Southern Blot para confirmar a cultura somente com mutantes, estes serão inoculados em plantas hospedeiras para análise funcional no hospedeiro. A seleção de colônias individuais expressando o gene $y f p$ será mais trabalhosa devido o fato de não existir um agente seletivo, que permita o crescimento diferenciado das colônias transformadas, como também existe o risco de perda das bactérias $X$. fastidiosa mutantes devido à ausência de uma pressão de seleção. A presença de um gene de resistência a antibiótico na construção dos plasmídeos vetores facilitaria a seleção destas bactérias mutantes. 
No trabalho de Souza (2002) não foi observado sintomas em plantas inoculadas com mutantes do operom gum de $X$. fastidiosa da linhagem J1a12 e nem com a linhagem selvagem controle, indicando que esta linhagem seja avirulenta ou tenha sua virulência reduzida. $\mathrm{O}$ autor sugere que é provável que a linhagem J1a12 seja uma linhagem naturalmente pouco virulenta ou que as sucessivas repicagens para a manutenção em laboratório, tenham comprometido a sua capacidade de colonizar a planta e desenvolver sintomas, apesar desta linhagem ter sido isolada de plantas sintomáticas para a CVC. Já foi comprovado que sucessivas repicagens em meio de cultura causa redução na virulência da linhagem 9a5c de $X$. fastidiosa (Monteiro et al., 2001a). Souza et al. (2003) também confirmaram a perda da patogenicidade da bactéria $X$. fastidiosa-CVC após 46 repicagens com relação à bactéria recém isolada da planta, e utilizando DNA microarray observaram que a maioria dos genes induzidos nesta última condição eram associados com a adesão e provavelmente com a adaptação ao ambiente do hospedeiro, sugerindo que a falta ou diminuição da expressão desses genes na bactéria que sofreu muitas repicagens em meio de cultura, poderia ser responsável pela alteração da sua patogenicidade.

Os mutantes produzidos neste trabalho poderão ser inoculados em plantas hospedeiras de tabaco (Lopes et al. 2000; Alves et al., 2003) ou vinca (Monteiro et al., 2001a) ou até mesmo em plantas de citros, para a análise funcional biológica da importância desses genes na patogenicidade da bactéria. Maiores esforços devem ser voltados para a obtenção de mutantes de $X$. fastidiosa da linhagem 9a5c, comprovadamente virulenta, para confirmação dos resultados que serão obtidos das plantas infectadas com mutantes de $X$. fastidiosa linhagem J1a12.

$X$. fastidiosa mutante para a adesina MsrA, além de ser inoculada em plantas hospedeiras também será utilizada para estudos do processo de adesão da bactéria no aparelho bucal e no trato intestinal de insetos vetores. Também seria importante a produção de mutantes de $X$. fastidiosa apresentado a disrupção de todas as ORFs que codificam exoenzimas simultaneamente, pois como apresentado anteriormente, existe a redundância de enzimas extracelulares produzidas por microorganismos (Görlach et al., 
1998) e a disrupção simultânea dessas ORFs poderá permitir melhor caracterização desta classe de enzimas na patogenicidade da bactéria. 


\section{CONCLUSÕES}

- Com o seqüenciamento e a observação da expressão da proteína amarela fluorescente em microscópio de fluorescência, dos plasmídeos pSG5, pSG15, pSG26 e pSG59 na bactéria $E$. coli, confirmou-se a correta construção dos vetores para a disrupção das ORFs Xf-818, Xf-2359, Xf-2708 e Xf-1940, respectivamente, utilizando a estratégia de substituição da ORF pelo gene $y f p$.

- Com a obtenção de colônias de E. coli apresentando os plasmídeos pSG31, pSG52 e pSG53, resistentes ao antibiótico canamicina e a expressão do gene lacZ conferindo coloração azul às colônias, em meio contendo substrato $\mathrm{X}$-Gal, foram confirmados a correta construção dos vetores para a disrupção das ORFs Xf-810 (pSG31) e Xf-1940 (pSG52 e pSG53), usando a estratégia de interromper a ORF com o cassete lacZ- $\mathrm{Km}^{\mathrm{R}}$.

- Obteve-se a disrupção das ORFs Xf-810, Xf-818, Xf-1940 e Xf-2359 de $X$. fastidiosa linhagem J1a12, confirmadas por PCR (Reação em Cadeia da Polimerase) utilizando oligonucleotídeos específicos, demonstrando a obtenção de bactérias mutantes.

- A seleção de colônias de bactérias de $X$. fastidiosa transformadas e individualizadas, poderão ser utilizadas como importante estratégia para estudo funcional dessas ORFs, que codificam exoenzimas e uma adesina, na patogenicidade da bactéria e nos estudos do mecanismo de disseminação da doença pelos insetos vetores. 


\section{ANEXOS}


Anexo A - Meio de cultura LB - “Luria-Bertani” (Sambrook et al., 1989):

$\begin{array}{ll}\text { Extrato de levedura ... } & 5 \mathrm{~g} \\ \mathrm{NaCl} \ldots \ldots \ldots \ldots \ldots \ldots \ldots \ldots . & 10 \mathrm{~g} \\ \text { Triptona .................. } & 10 \mathrm{~g} \\ \text { Água destilada ........... } & \text { completa para } 1 \mathrm{~L}\end{array}$

$\mathrm{O} \mathrm{pH}$ do meio era de 7,0. O meio de cultura foi esterilizado através de autoclavagem a $121^{\circ} \mathrm{C}, 1 \mathrm{~atm}$, durante 20 minutos. Para o preparo do meio sólido, adicionou-se $15 \mathrm{~g} / \mathrm{L}$ de ágar antes da autoclavagem. 


\section{Anexo B - Preparo de células competentes de Escherichia coli}

1) Pré inocular "over night", em $10 \mathrm{~mL}$ de meio SOB, uma colônia de E. coli DH5 $\alpha$ de uma placa de LB recente, incubar a $37^{\circ} \mathrm{C}$ por 16 horas, sob agitação constante de $220 \mathrm{rpm} ;$

2) Inocular $1 \mathrm{~mL}$ do pré-inóculo em $100 \mathrm{~mL}$ de meio $\mathrm{SOB}$ enriquecido com $1 \mathrm{~mL}$ de $\mathrm{MgSO}_{4} 1 \mathrm{M} \mathrm{e} 1 \mathrm{~mL}$ de $\mathrm{MgCl}_{2} 1 \mathrm{M}$, incubar nas mesmas condições de temperatura e rotação até atingir D. $0.600 \mathrm{~nm}$ entre 0,45 a 0,55 ;

3) Transferir a cultura para tubo de $200 \mathrm{~mL}$ de polipropileno da centrífuga Sorvall GSA autoclavado e a $0^{\circ} \mathrm{C}$, e deixar no gelo por 10 minutos. A cultura foi centrifugada a $3500 x g$ por 10 minutos, a $4^{\circ} \mathrm{C}$. O sobrenadante foi descartado;

4) O precipitado resultante foi ressuspendido em $15 \mathrm{~mL}$ de tampão $\mathrm{RF} 1$ gelado e deixado no gelo por 15 minutos;

5) Em seguida a suspensão foi centrifugada a $3000 \mathrm{xg}$, por 10 minutos, a $4^{\circ} \mathrm{C}$;

6) O sobrenadante foi descartado e o precipitado ressuspendido em $8 \mathrm{~mL}$ de tampão RF2 gelado e foi deixado no gelo por 30 minutos;

7) Alíquotas de $200 \mu \mathrm{L}$ foram distribuídas em tubos de microcentrifuga de 1,5 mL previamente resfriados. Esses tubos foram congelados em nitrogênio líquido e estocados $\mathrm{a}-70^{\circ} \mathrm{C}$ até o momento de uso. 


\section{SOB (para $1 \mathrm{~L}$ ):}

Triptona …........... $20 \mathrm{~g}$

Extrato de levedura . $5 \mathrm{~g}$

$\mathrm{NaCl} \ldots \ldots \ldots \ldots \ldots \ldots \ldots . . . . . . . .586 \mathrm{~g}$

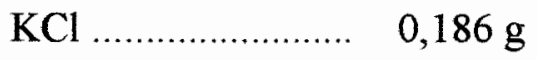

RF1 (para $250 \mathrm{~mL}$ ):

KAc $30 \mathrm{mM}$.......... $\quad 7,5 \mathrm{~mL}$ solução $1 \mathrm{M} \mathrm{pH} \mathrm{7,5}$

$\mathrm{RbCl} 100 \mathrm{mM} \ldots \ldots . . .3 \mathrm{~g}$

$\mathrm{MnCl} 50 \mathrm{mM} \ldots \ldots \ldots . \quad 2,5 \mathrm{~g}$

$\mathrm{CaCl}_{2} 10 \mathrm{mM} \ldots \ldots \ldots . .0,38 \mathrm{~g}$

Glicerol $15 \%(\mathrm{p} / \mathrm{v}) . . \quad 37,5 \mathrm{~g}$

Ajustar o $\mathrm{pH}$ para 5,8 com ácido acético $0,2 \mathrm{M}$ e filtrar em millipore $0,2 \mu \mathrm{m}$.

RF2 (para $250 \mathrm{~mL}$ ):

MOPS $10 \mathrm{mM}$........ $5 \mathrm{~mL}$ solução $0,5 \mathrm{M} \mathrm{pH} \mathrm{6,8}$

$\mathrm{RbCl} 10 \mathrm{mM} \ldots \ldots \ldots \ldots . \quad 0,3 \mathrm{~g}$

$\mathrm{CaCl}_{2} 75 \mathrm{mM} \ldots \ldots \ldots . . .2,75 \mathrm{~g}$

Glicerol $15 \%(\mathrm{p} / \mathrm{v}) \ldots \quad 37,5 \mathrm{~g}$

Ajustar o $\mathrm{pH}$ para $6,8 \mathrm{com} \mathrm{NaOH} 2,0 \mathrm{M}$. 
Anexo C - Preparo de X-Gal/IPTG 2X

\begin{tabular}{|c|c|}
\hline X-Gal ............... & $0,2 \mathrm{~g}$ \\
\hline IPTG & $0,048 \mathrm{~g}$ \\
\hline $\mathrm{MF}$ & $10 \mathrm{~mL}$ \\
\hline
\end{tabular}


Anexo D - Tampão CTAB $10 \%$ (para $100 \mathrm{~mL})$ :

$\mathrm{CTAB} \ldots \ldots \ldots \ldots \ldots \ldots \ldots \ldots \ldots \ldots \ldots$

$\mathrm{NaCl} 1,4 \mathrm{M}$.................... $28 \mathrm{~mL}$ de $\mathrm{NaCl} 5 \mathrm{M}$

EDTA $100 \mathrm{mM}$.............. $4 \mathrm{~mL}$ EDTA 0,5 M

Tris- $\mathrm{HCl} 100 \mathrm{mM} \mathrm{pH} \mathrm{8,0 \ldots 10} \mathrm{mL} \mathrm{Tris-} \mathrm{HCl} 1 \mathrm{M}$ 


\section{REFERÊNCIAS BIBLIOGRÁFICAS}

ADAIKKALAM, V.; SWARUP, S. Molecular characterization of an operon, cueAR, encoding a putative P1-type ATPase and a MerR-type regulatory protein involved in copper homeostasis in Pseudomonas putida. Microbiology, v.148, n.9, p.2857$2867,2002$.

AHN, J.H.; SPOSATO, P.; KIM, S.I.; WALTON, J.D. Molecular cloning and characterization of cel2 from the fungus Cochlibolus carbonum. Bioscience, Biotechnology, and Biochemistry, v.65, n.6, p.1406-1411, 2001.

ALBIBI, R.; CHEN, J.; LAMIKANRA, O.; BANKS, D.; JARRET, R.L.; SMITH, B.J. RAPD fingerprinting Xylella fastidiosa Pierce's disease strains isolated from a vineyard in North Florida. FEMS Microbiology Letters, v.165, n.2, p.347-352, 1998.

ALMEIDA, R.P.P.; PEREIRA, E.F.; PURCELL, A.H. Multiplication and movement of a citrus strain of Xylella fastidiosa within sweet orange. Plant Disease, v.85, n.4, p.382-386, 2001.

ALVES, E. Xylella fastidiosa adesão e colonização em vasos do xilema de laranjeira doce, cafeeiro, ameixeira, fumo e espécies de cigarrinhas vetoras e formação de biofilme sobre película de poliestireno. Piracicaba, 2003. 122p. Tese (Doutorado) Escola Superior de Agricultura "Luiz de Queiroz", Universidade de São Paulo.

ALVES, E.; KITAJIMA, E.W.; LEITE, B. Interaction of Xylella fastidiosa with different cultivars of Nicotiana tabacum: a comparison of colonization patterns. Journal of Phytopathology, v.151, n.9, p.500-506, 2003. 
ARAUJO, W.L.; MARCON, J.; MACCHERONI W. J.; VAN ELSAS, J.D; VAN VUURDE, J.W.; AZEVEDO, J.L. Diversity of endophytic bacterial populations and their interaction with Xylella fastidiosa in citrus plants. Applied and Environmental Microbiology, v.68, n.10, p.4906-4914, 2002.

BANKS, D.; ALBIBI, R.; CHEN, J.; LAMIKANRA, O.; JARRET, R.L.; SMITH, B.J. Specific detection of Xylella fastidiosa Pierce's disease strains. Current Microbiology, v.39, n.2, p.85-88, 1999.

BARBER, C.E.; TANG, J.L.; FENG, J.X.; PAN, M.Q.; WILSON, T.J.; SLATER, H.; DOW, J.M.; WILLIAMS, P.; DANIELS, M.J. A novel regulatory system required for pathogenicity of Xanthomonas campestris is mediated by a small diffusible signal molecule. Molecular Microbiology, v.24, n.3, p.555-566, 1997.

BAULARD, A.; KREMER, L; LOCHT, C. Efficient homologous recombination in fast-growing and slow-growing mycobacteria. Journal of Bacteriology, v.178, n.11, p.3091-3098, 1996.

BEKRI, M.A.; DESAIR, J.; KEIJERS, V.; PROOST, P., SEARLE-VAN LEEUWEN, M.; VANDERLEYDEN, J; VANDE BROEK, A. Azospirillum irakense produces a novel type of pectate lyase. Journal of Bacteriology, v.181, n.8, p.2440-2447, 1999.

BERA-MAILLET, C.; RIBOT, Y.; FORANO, E. Fiber-degrading systems of different strains of the genus Fibrobacter. Applied and Environmental Microbiology, v.70, n. 4, p. 2172-2179, 2004.

BERETTA, M. J. G.; BARTHE, G. A.; CECCARDI, T. L.; LEE, R. F.; DERRICK, K. S. Survey for strains of Xylella fastidiosa in citrus affected by citrus variegated chlorosis and citrus blight in Brazil. Plant Disease, v.81, n.10, p.1196-1198, 1997.

BHAT, M.K. Cellulases and related enzymes in biotechnology. Biotechnology Advances, v. 18, n.5, p.355-383, 2000.

BHATTACHARYYA, A; STILWAGEN, S; IVANOVA, N. et al. Whole-genome comparative analysis of three phytopathogenic Xylella fastidiosa strains. Proceedings of The National Academy of Sciences Of The United States of America, v.99, n.19, p.12403-12408, 2002. 
BOCCARA, M; AYMERIC, J.L.; CAMUS, C. Role of endoglucanases in Erwinia chrysanthemi 3937 virulence on Saintpaulia ionantha. Journal of Bacteriology, v. 176, n. 5, p. $1524-1526,1994$.

BOISNARD-LORIG, C.; COLON-CARMONA, A.; BAUCH, M; HODGE, S.; DOERNER, P.; BANCHAREL, E.; DUMAS, C.; HASELOFF, J; BERGER, F. Dynamic analyses of the expression of the HISTONE::YFP fusion protein in arabidopsis show that syncytial endosperm is divided in mitotic domains. Plant Cell, v.13, n.3, p.495-509, 2001.

BOLTE, S.; BROWN, S.; SATIAT-JEUNEMAITRE, B. The N-myristoylated RabGTPase $\mathrm{m}$-Rabmc is involved in post-Golgi trafficking events to the lytic vacuole in plant cells. Journal of Cell Science, v.117, n.6, p.943-954, 2004.

BOWEN, J.K.; TEMPLETON, M.D.; SHARROCK, K.R.; CROWHURST, R.N.; RIKKERINK, E.H. Gene inactivation in the plant pathogen Glomerella cingulata: three strategies for the disruption of the pectin lyase gene pnlA. Molecular And General Genetics, v.246, n.2, p.196-205, 1995.

BRLANSKY, R.H.; DAVIS, C.L.; TIMMER, L.W.; HOWD, D.S.; CONTRERAS, J. Xylem-limited bacteria in citrus from Argentina with symptoms of citrus variegated chlorosis. Phytopathology, v.81, p.1210, 1991.

BRLANSKY, R.H.; TIMMER, L.W.; FRENCH, W.J.; MCCOY, R.E. Colonization of the sharpshooter vactors Oncometopia nigricans and Homalodisca coagulate by xylem-limited bacteria. Phytopathology, v.73, n.4, p.530-535, 1983.

BROT, N.; WEISSBACH, L.; WERTH, J.; WEISSBACH, H. Enzymatic reduction of protein-bound methionine sulfoxide. Proceedings Of The National Academy of Sciences Of The United States Of America, v.78, n.4, p.2155-2158, 1981.

CAO, T.B.; SAIER, M.H.J. Conjugal type IV macromolecular transfer systems of Gram-negative bacteria: organismal distribution, structural constraints and evolutionary conclusions. Microbiology, v.147, n.12, p.3201-3214, 2001.

CARLOS, E.F.; RODRIGUES NETO, J.; BERETTA, M.J.G. A bactéria Xylella fastidiosa. In: DONADIO, L.C.; MOREIRA, C.S. Clorose variegada dos citros. Araraquaral: Fundecitrus, 1997. p.22-36. 
CARPITA, N. C.; GIBEAUT, D.M. Structural models of primary cell walls in flowering plants: consistency of molecular structure with the physical properties of the walls during growth. The Plant Journal, v.3, n.1, p.1-30, 1993.

CARVALHO, M.L.V.; ROSSETTI, V.; POMPEU, J.R.J. Evolução da sintomatologia de clorose variegada dos citros em laranja doce (C. sinensis). Fitopatologia Brasileira, v. 20, Supl. p.351, 1995. Suplemento.

CHAGAS, C. M.; ROSSETTI, V.; BERETTA, M. J. G. Electron-microscopy studies of a xylem-limited bacterium in sweet orange affected with citrus variegated chlorosis disease in Brazil. Journal of Phytopathology, v.134, n.4, p.306-312, 1992.

CHANG, C.L.; GARNIER, M.; ZREIK, L.; ROSETTI, V.; BOVÉ, J.M. Culture and serological detection of the bacterium causing CVC-a strain of Xylella fastidiosa. Current Microbiology, v.27, n.3, p.137-142, 1993.

CHANG, J.H.; GOEL, A.K.; GRANT, S.R.; DANGL, J.L. Wake of the flood: ascribing functions to the wave of type III effector proteins of phytopathogenic bacteria. Current Opinion in Microbiology, v.7, n. 1, p.11-18, 2004.

CHEN, J.; CHANG, C.J.; JARRET, R.L.; GAWEL, N. Genetic variation among Xylella fastidiosa strains. Phytopathology, v.82, n.9, p.973-977, 1992.

CHEN, J.; LAMIKANRA, O.; CHANG, C.J.; HOPKINS, D.L. Randomly amplified polymorphic DNA analysis of Xylella fastidiosa Pierce's disease and oak leaf scorch pathotypes. Applied and Environmental Microbiology, v.61, n.5, p.1688-1690, 1995.

CHEN, J.; JARRET, R.L.; QIN, X.; HARTUNG, J.S.; BANKS, D.; CHANG, C.J.; HOPKINS, D.L. 16S rDNA sequence analysis of Xylella fastidiosa strains. Systematic and Applied Microbiology, v.23, n.3, p.349-354, 2000.

CODY, C.W.; PRASHER, D.C.; WESTLER, W.M.; PRENDERGAST, F.G.; WARD, W.W. Chemical structure of the hexapeptide chromophore of the Aequorea greenfluorescent protein. Biochemistry, v.32, n.5, p.1212-1218, 1993.

DANGL, J.L.; JONES, J.D.G. Plant pathogens and integrated defence responses to infection. Nature, v.411, n.6839, p. 826-833, 2001. 
DAVIS, M.J.; PURCELL, A.H.; THOMSON, S.V. Pierce's disease of grapevines: isolation of the causal bacterium. Science, v.199, n.1, p.75-77, 1978.

DELLA COLETTA-FILHO, H.; MACHADO, M.A. Evaluation of the genetic structure of Xylella fastidiosa populations from different Citrus sinensis varieties. Applied and Environmental Microbiology, v.68, n.8, p.3731-3736, 2002.

DE NEGRI, J.D.; GARCIA JUNIOR, A. Sugestões para o manejo de pomares com clorose variegada de citros. Laranja, v.14, n.1, p.255-267, 1993.

DHANDAYUTHAPANI, S.; BLAYLOCK, M.W; BEBEAR, C.M.; RASMUSSEN, W.G.; BASEMAN, J.B. Peptide methionine sulfoxide reductase (MsrA) is a virulence determinant in Mycoplasma genitalium. Journal of Bacteriology, v.183, n. 19, p.5645-5650, 2001.

DONADIO, L.D.; MOREIRA, C.S. Clorose variegada dos citros. Bebedouro: Estação Experimental de Citricultura de Bebedouro, 1997. 162p.

DONOVAN, W.P.; DONOVAN, J.C.; ENGLEMAN, J.T Gene knockout demonstrates that vip $3 A$ contributes to the pathogenesis of Bacillus thuringiensis toward Agrotis ipsilon and Spodoptera exigua. Journal of Invertebrate Pathology, v.78, n.1, p.45$51,2001$.

DOUGLAS, T.; DANIEL, D.S.; PARIDA, B.K.; JAGANNATH, C.; DHANDAYUTHAPANI, S. Methionine sulfoxide reductase A (MsrA) deficiency affects the survival of Mycobacterium smegmatis within macrophages. Journal of Bacteriology, v.186, n.11, p.3590-3598, 2004.

DOW, J.M; DANIELS, M.J. Xylella genomics and bacterial pathogenicity to plants. Yeast, v.17, n.4, p.263-271, 2000.

DOW, J.M.; SCOFIELD, G.; TRAFFORD, K.; TURNER, P.C.; DANIELS, M.J. A gene cluster in Xanthomonas campestris pv. campestris required for pathogenicity controls the excretion of polygalacturonate lyase and other enzymes. Physiological and Molecular Plant Pathology, v.31, n.2, p.261-271, 1987.

DOW, J.M.; FENG, J.X.; BARBER, C.E.; TANG, J.L.; DANIELS, M.J. Novel genes involved in the regulation of pathogenicity factor production within the rpf gene cluster of Xanthomonas campestris. Microbiology, v.146, n.4, p.885-891, 2000. 
DUMS, F.; DOW, J.M.; DANIELS, M.J. Structural characterization of protein secretion genes of the bacterial phytopathogen Xanthomonas campestris pathovar campestrisrelatedness to secretion systems of other Gram-negative bacteria. Molecular and General Genetics, v.229, n.3, p.357-364, 1991.

DUQUE, P.; CHUA, N.H. IMB1, a bromodomain protein induced during seed imbibition, regulates $\mathrm{ABA}$ - and phyA-mediated responses of germination in Arabidopsis. The Plant Journal, v.35, n.6, p.787-799, 2003.

FEIL, H.; FEIL, W.S.; DETTER, J.C.; PURCELL, A.H.; LINDOW, S.E. Site-directed disruption of the fimA and fimB fimbrial genes of Xylella fastidiosa. Bacteriology, v.93, n.6, p.675-682, 2003.

FERNANDEZ, L.A.; BERENGUER, J. Secretion and assembly of regular surface structures in Gram-negative bacteria. FEMS Microbiology Reviews, v.24, n.1, p. $21-44,2000$.

FERREIRA, H.; RODRIGUES NETO, J.; GONÇALVES, E.R.; ROSATO, Y.B. A simplified subtractive hybridization protocol used to isolate DNA sequences specific to Xylella fastidiosa. Microbiology, v.145, n.8, p.1967-1975, 1999.

FINLAY, B.B.; FALKOW, S. Common themes in microbial pathogenicity revisited. Microbiology and Molecular Biology Reviews, v.61, n.2, p136-169, 1997.

FUNDO DE DEFESA DA CITRICULTURA (FUNDECITRUS). Estatísticas: clorose variegada dos citros. http://www.fundecitrus.com.br/ (05 maio 2004).

GAURIVAUD, P.; SOUZA, L.C.; VIRGILIO, A.C.; MARIANO, A.G.; PALMA, R.R.; MONTEIRO, P.B. Gene disruption by homologous recombination in the Xylella fastidiosa citrus variegated chlorosis strain. Applied and Environmental Microbiology, v.68, n.9, p.4658-4665, 2002.

GOHEEN, A.C.; NYLAND, G.; LOWE, S.K. Association a riccketsialike organism with Pierce's disease of grapevinessand alfafa dwarf and heat therapy of the disease in grapevines. Phytopathology, v.63, n.3, p.341-345, 1973. 
GORLACH, J.M.; VAN DER KNAAP, E.; WALTON, J.D. Cloning and targeted disruption of $M L G 1$, a gene encoding two of three extracellular mixed-linked glucanases of Cochliobolus carbonum. Applied and Environmental Microbiology, v.64, n.2, p.385-391, 1998.

GOUGH, C.L.; DOW, J.M.; BARBER, C.E.; DANIELS, M.J. Cloning of two endoglucanase genes of Xanthomonas campestris pv. campestris. Molecular Plant Microbe Interactions, v.1, p.275-281, 1988.

GOUGH, C.L.; DOW, J.M.; KEEN, J.; HENRISSAT, B.; DANIELS, M.J. Nucleotide sequence of the engXCA gene encoding the major endoglucanase of Xanthomonas campestris pv. campestris. Gene, v.89, n.1, p.53-59, 1990.

GRIESBECK, O.; BAIRD, G.S.; CAMPBELL, R.E.; ZACHARIAS, D.A.; TSIEN, R.Y. Reducing the environmental sensitivity of yellow fluorescent protein. The Journal of Biological Chemistry, v.276, n.31, p.29188-29194, 2001.

GUILHABERT, M.R.; HOFFMAN, L.M.; MILLS, D.A.; KIRKPATRICK, B.C. Transposon mutagenesis of Xylella fastidiosa by electroporation of Tn5 synaptic complexes. Molecular Plant Microbe Interactions, v. 14, n.6, p.701-706, 2001.

GUILHABERT, M.R.; KIRKPATRICK, B.C. Transformation of Xylella fastidiosa with broad host range RSF1010 derivative plasmids. Molecular Plant Pathology, v.4, n.4, p. 279-285, 2003.

HAMILTON, H.L.; SCHWARTZ, K.J.; DILLARD, J.P. Insertion-duplication mutagenesis of neisseria: use in characterization of DNA transfer genes in the gonococcal genetic island. Journal of Bacteriology, v.183, n.16, p.4718-4726, 2001.

HANAHAN, D. Transformation of Escherichia coli with plasmids. Journal of Molecular Biology, v.166, n.4, p.557-580, 1983.

HARTUNG, J.S.; BERETTA, M.J.G.; BRLANSKY, R.H.; SPISSO, J.; LEE, R.F. Citrus variegated chlorosis bacterium: axenic culture, pathogenicity and serological relationships with other strains of Xylella fastidiosa. Phytopathology, v.84, n.6, p.591-597, 1994. 
HASSOUNI, M.E.; CHAMBOST, J.P.; EXPERT, D.; VAN GIJSEGEM, F.; BARRAS, F. The minimal gene set member $m s r A$, encoding peptide methionine sulfoxide reductase, is a virulence determinant of the plant pathogen Erwinia chrysanthemi. Proceedings of The National Academy of Sciences Of The United States Of America, v.96, n.3, p.887-892, 1999.

HEIM, R.; PRASHER, D.C.; TSIEN, R.Y. Wavelength mutations and posttranslational autoxidation of green fluorescent protein. Proceedings Of The National Academy Of Sciences Of The United States Of America, v.91, n.26, p.12501-12504, 1994.

HENDAWY, H.H.; FREER, J.H.; CLARKE, D.D; ABYAD, M.S.; SALEH, Y.E. Pectate lyase isozymes and the pathogenicity of soft rotting strains of Erwinia for melon and cucumber. Microbiological Research, v.152, n.4, p.331-339, 1997.

HERRON, S.R.; BENEN, J.A.E.; SCAVETTA, R.D.; VISSER, J.; JURNAK, F. Structure and function of pectic enzymes: Virulence factors of plant pathogens. Proceedings of The National Academy of Sciences of The United States of America, v.97, n.16, p.8762-8769, 2000.

HE, S.Y.; JIN, Q. The Hrp pilus: learning from flagella. Current Opinion in Microbiology, v.6, n.1, p.15-19, 2003.

HILL, B.L.; PURCELL, A.H. Acquisition and retention of Xylella fastidiosa by an efficient vector, Graphocephala atropunctata. Phytopathology, v.85, n.2, p.209$212,1995$.

HOPKINS, D.L. Xylella fastidiosa and other fastidious bacteria of uncertain affiliation. In: SCHAAD, N.W. (Ed.) Laboratory guide for identification of plant pathogenic bacteria, 2. ed. St. Paul: APS Press, p.95-113, 1988.

HOPKINS, D.L. Xylella fastidiosa: a xylem-limited bacterial pathogen of plants. Annual Review of Phytopathology, v.27, p.271-290, 1989.

HOPKINS, D.L.; MOLLENHAUER, H.H. Rickettsia-like bacterium associated with Pierce's disease of grapes. Science, v.179, p.298-300, 1973.

HUANG, G.Z.; ZHANG, L.H.; BIRCH, R.G. Characterization of the acyl carrier protein gene and the fab gene locus in Xanthomonas albilineans. FEMS Microbiology Letters, v. 193, n.1, p. 129-136, 2000. 
INSTITUTO BRASILEIRO DE GEOGRAFIA E ESTATÍSTICA (IBGE). Levantamento Sistemático da Produção Agrícola. http://www.ibge.gov.br/ (01 jun. 2004).

JAHR, H.; DREIER, J.; MELETZUS, D.; BAHRO, R.; EICHENLAUB, R. The endo$\beta$-1,4-glucanase of Clavibacter michiganensis subsp. michiganensis is a pathogenicity determinant required for induction of bacterial wilt of tomato. Molecular Plant Microbe Interactions, v.13, n.7, p.703-714, 2000.

JOHN, G.S.; BROT, N.; RUAN, J.; ERDJUMENT-BROMAGE, H.; TEMPST, P.; WEISSBACH, H.; NATHAN, C. Peptide methionine sulfoxide reductase from Escherichia coli and Mycobacterium tuberculosis protects bacteria against oxidative damage from reactive nitrogen intermediates. Proceedings of the National Academy of Sciences of the United States of America, v.98, n.17, p.9901-9906, 2001.

KAIN, S.R. Green fluorescent protein (GFP): applications in cell-based assays for drug discovery. Drug Discovery Today, v.4, n.7, p.304-312, 1999.

KAISER, D.; LOSICK, R. How and why bacteria talk to each other. Cell, v.73, n.5, p.873-885, 1993.

KATZEN, F.; FERREIRO, D.U.; ODDO, C.G.; IELMINI, M.V.; BECKER, A.; PUHLER, A.; IELPI, L. Xanthomonas campestris pv. campestris gum mutants: effects on xanthan biosynthesis and plant virulence. Journal of Bacteriology, v.180, n.7, p.1607-1617, 1998.

KEEN, N.T.; DUMENYO, C.K.; YANG, C.H.; COOKSEY, D.A. From rags to riches: insights from the first genomic sequence of a plant pathogenic bacterium. Genome Biology, v.1, n.3, p.1019.1-1019.4, 2000.

KERR, J.R. Cell adhesion molecules in the pathogenesis of and host defence against microbial infection. Molecular Pathology, v.52, n.4, p.220-230, 1999.

KOIDE, T.; DA SILVA NETO, J.F.; GOMES, S.L.; MARQUES, M.V. Insertional transposon mutagenesis in the Xylella fastidiosa Citrus Variegated Chlorosis strain with transposome. Current Microbiology, v.48, n.4, p.247-250, 2004. 
KOKOTEK, W.; LOTZ, W. Construction of a lacZ-kanamycin-resistence cassete, useful for site-directed mutagenesis and as a promoter probe. Gene, v. 84, n.2, p.467-471, 1989.

KOLPAK, F.J.; BLACKWELL, J. Determination of the structure of cellulose II. Macromolecules, v.9, p.273-278, 1976.

KOSTKA, S.J.; TATTAR, T.A.; SHERALD, J.L. Elm leaf scorch: abnormal physiology in American elms infected with fastidious, xylem-inhabiting bacteria. Canadian Journal of Forest Research, v. 16, p.1088-1091, 1986.

KRETZSCHMAR, A.K.; DINGER, M.C.; HENZE, C.; BROCKE-HEIDRICH, K.; HORN, F. Analysis of Stat3 (signal transducer and activator of transcription 3) dimerization by fluorescence resonance energy transfer in living cells. Biochemical Jourmal, v.377, n.2, p.289-297, 2004.

KUSCHEL, L.; HANSEL, A.; SCHOHERR, R.; WEISSBACH, H.; BROT, N.; HOSHI, T.; HEINEMANN, S.H. Molecular cloning and functional expression of a human peptide methionine sulfoxide reductase (hMsrA). FEBS Letters, v.456, n.1, p.17$21,1999$.

LAINE, M.J.; HAAPALAINEN, M.; WAHLROSS, T.; KANKARE, K.; NISSINEN, R.; KASSUWI, S.; METZLER, M.C. The cellulase encoded by the native plasmid of Clavibacter michiganensis ssp. sepedonicus plays a role in virulence and contains an expansin-like domain. Physiology and Molecular Plant Pathology, v.57, n.5, p.221-233, 2000.

LAMBAIS, M.R.; GOLDMAN, M.H.; CAMARGO, L.E.; GOLDMAN, G.H. A genomic approach to the understanding of Xylella fastidiosa pathogenicity. Current Opinion in Microbiology, v.3, n.5, p.459-462, 2000.

LEE, M.S.; SEOK, C.; MORRISON, D.A. Insertion-duplication mutagenesis in Streptococcus pneumoniae: targeting fragment length is a critical parameter in use as a random insertion tool. Applied and Environmental Microbiology, v.64, n. 12, p.4796-4802, 1998 . 
LEE, R.F.; DERRICK, K.F.; BERETTA, M.J.G.; CHAGAS, C.M.; ROSETTI, V. Citrus variegated chlorosis: a new destructive disease of citrus in Brazil. Citrus Industry, v.72, n. 10, p.12-13, 1991.

LEE, V.T.; SCHNEEWIND, O. Protein secretion and the pathogenesis of bacterial infections. Genes \& Development, v.15, n. 14, p.1725-1752, 2001.

LEITE, B.; ISHIDA, M.L.; ALVES, E.; CARRER, H.; PASCHOLATI, S.F.; KITAJMA, E.W. Genomics and X-ray microanalysis indicate that $\mathrm{Ca}^{2+}$ and thiols mediate the aggregation and adhesion of Xylella fastidiosa. Brazilian Journal of Medical and Biological Research, v.35, n.6, p.645-650, 2002.

LEITE, B.; PASCHOLATI, S.F.; KITAJIMA, E.W.; ISHIDA, M.L. Mecanismos de adesão de bactérias e fungos às plantas hospedeiras. Revisão Anual de Patologia de Plantas, v.9, p.119-157, 2001.

LEITE, R.M.V.B.C.; LEITE Júnior., R.P.; CERESINI, P.C. Hospedeiros alternativos de Xylella fastidiosa entre plantas invasoras de pomares de amexeira com escaldadura da folha. Fitopatologia Brasileira, v.22, n.1, p.54-57, 1997.

LEMOS, E.G.; ALVES, L.M.; CAMPANHARO, J.C. Genomics-based design of defined growth media for the plant pathogen Xylella fastidiosa. FEMS Microbiology Letters, v.219, n.1, p.39-45, 2003.

LEU, L.S.; SU, C.C. Isolation, cultivation, and pathogenicity of Xylella fastidiosa, the causal bacterium of pear leaf scorch disease in Taiwan. Plant Disease, v.77, n.7, p.642-646, 1993.

LIAO, C.H. Analysis of pectate lyase produced by soft rot bacteria associated with spoilage of vegetables. Applied and Environmental Microbiology, v.55, n.7, p.1677-1683, 1989.

LIAO, C.H.; HUNG, H.Y.; CHATTERJEE, A.K. An extracellular pectate lyase is the pathogenicity factor of the soft-rotting bacterium Pseudomonas viridiflava. Molecular Plant Microbe Interactions, v.1, p.199-206, 1988. 
LIAO, C.H.; MCCALLUS, D.E.; FETT, W.F. Molecular characterization of two gene loci required for production of the key pathogenicity factor pectate lyase in Pseudomonas viridiflava. Molecular Plant Microbe Interactions, v.7, n.3, p.391$400,1994$.

LIAO, C.H.; GAFFNEY, T.D.; BRADLEY, S.P.; WONG, L.C. Cloning of a pectate lyase gene from Xanthomonas campestris pv. malvacearum and comparison of its sequence relationship with pel genes of soft-rot Erwinia and Pseudomonas. Molecular Plant Microbe Interactions, v.9, n.1, p. 14-21, 1996.

LIETZKE, S.E; YODER, M.D.; KEEN, N.T.; JURNAK, F. The three-dimensional structure of pectate lyase e, a plant virulence factor from Erwinia chrysanthemi. Plant Physiology, v.106, n.3, p.849-862, 1994.

LI, W.B.; ZHOU, C.H.; PRIA, W.D.; TEIXEIRA, D.C.; MIRANDA, V.S.; PEREIRA, E.O.; AYRES, A.J.; HARTUNG, J.S. Citrus and coffee strains of Xylella fastidiosa induce Pierce's disease in grapevine. Plant Disease, v.86, n. 11, p. 1206-1210, 2002.

LIMA, J.E.O; MIRANDA, V.S.; HARTUNG, J.S.; BRLANSKY, R.H.; COUTINHO, A.; ROBERTO, S.R., CARLOS, E.F. Coffee leaf scorch bacterium: axenic culture, pathogenicity, and comparision with Xylella fastidiosa of citrus. Plant Disease, v.82, n.1, p.94-97, 1998 .

LONG, S.R.; STASKAWICS, B.L. Prokaryotic plant parasites. Cell, v.73, p.921-935, 1993.

LOPES, S.A.; ROBERTO, P.G; FRANÇA, S.C. Hospedeiros alternativos da Xylella fastidiosa dos citros. Fitopatologia Brasileira, v.24, Supl. p.250, 1999. Suplemento.

LOPES, S.A.; RIBEIRO, D.M.; ROBERTO, P.G.; FRANCA, S.C.; SANTOS, J.M. Nicotiana tabacum as an experimental host for the study of plant - Xylella fastidiosa interactions. Plant Disease, v.84, n.8, p.827-830, 2000.

LOWTHER, W.T.; BROT, N.; WEISSBACH, H.; HONEK, J.F.; MATTHEWS, B.W. Thiol-disulfide exchange is involved in the catalytic mechanism of peptide methionine sulfoxide reductase. Proceedings of the National Academy of Sciences of the United States of America, v.97, n.12, p.6463-6468, 2000. 
MACHADO, M.A.; SILVÉRIO, J.L.; BAPTISTA, C.R.; CRISTOFANI, M.. Avaliação de transmissão e seleção de variedades à clorose variegada dos citros (CVC). Laranja, v.13, n.2, p.515-531, 1992.

MAE, A.; HEIKINHEIMO, R.; PALVA, E.T. Structure and regulation of the Erwinia carotovora subspecies carotovora SCC3193 cellulase gene celVI and the role of cellulase in phytopathogenicity. Molecular and General Genetics, v.247, n.1, p.17-26, 1995.

MALHOTRA, V.; SHARMA, D; RAMANATHAN, V.D.; SHAKILA, H.; SAINI, D.K.; CHAKRAVORTY, S.; DAS, T.K.; LI, Q.; SILVER, R.F.; NARAYANAN, P.R.; TYAGI, J.S. Disruption of response regulator gene, devR, leads to attenuation in virulence of Mycobacterium tuberculosis. FEMS Microbiology Letters, v.231, n.2, p.237-245, 2004.

MCELRONE, A.J.; SHERALD, J.L.; FORSETH, I.N. Effects of water stress on symptomatology and growth of Parthenocissus quinquefolia infected by Xylella fastidiosa. Plant Disease, v.85, p.1160-1164, 2001.

MCELRONE, A.J.; SHERALD, J.L.; FORSETH, I.N. Interactive effects of water stress and xylem-limited bacterial infection on the water relations of a host vine. Journal of Experimental Botany, v.54, n.381, p.419-430, 2003.

MCNEILL, M.; DARVILL, A.G.; FRY, S.C.; ALBERSHEIM, P. Structure and function of the primary cell walls of plants. Annual Review of Biochemistry, v.53, p.625-663, 1984.

MILLER, W.G.; BATES, A.H.; HORN, S.T.; BRANDL, M.T.; WACHTEL, M.R.; MANDRELL, R.E. Detection on surfaces and in Caco-2 cells of Campylobacter jejuni cells transformed with new gfp, yfp, and cfp marker plasmids. Applied and Environmental Microbiology, v.66, n.12, p.5426-5436, 2000.

MIRCETICH, S.M; LOWE, S.K.; MOLLER, W.J.; NYLAND, G. Etiology of the almond leaf scorch disease and transmission of the causal agent. Phytopathology, v.66, n.1, p.17-24, 1976. 
MONTEIRO, P.B; RENAUDIN, J; JAGOUEIX-EVEILLARD, S.; AYRES, A.J.; GARNIER, M; BOVÉ, J.M. Catharanthus roseus, an experimental host plant for citrus strain of Xylella fastidiosa. Plant Disease, v.86, n.3, p.246-251, 2001 a.

MONTEIRO, P.B.; TEIXEIRA, D.C.; PALMA, R.R.; GARNIER, M.; BOVE, J.M.; RENAUDIN, J. Stable transformation of the Xylella fastidiosa citrus variegated chlorosis strain with oriC plasmids. Applied and Environmental Microbiology, v.67, n.5, p.2263-2269, 2001b.

MORRISON, D.A.; TROMBE, M.C.; HAYDEN, M.K.; WASZAK, G.A.; CHEN, J.D. Isolation of transformation-deficient Streptococcus pneumoniae mutants defective in control of competence, using insertion-duplication mutagenesis with the erythromycin resistance determinant of pAM beta 1. Journal of Bacteriology, v.159, n.3, p.870-876, 1984.

MOSKOVITZ, J.; FLESCHER, E.; BERLETT, B.S.; AZARE, J.; POSTON, J.M.; STADTMAN, E.R. Overexpression of peptide-methionine sulfoxide reductase in Saccharomyces cerevisiae and human $\mathrm{T}$ cells provides them with high resistance to oxidative stress. Proceedings of The National Academy Of Sciences of The United States Of America, v.95, n.24, p.14071-14075, 1998.

MOSKOVITZ, J.; JENKINS, N.A.; GILBERT, D.J.; COPELAND, N.G.; JURSKY, F.; WEISSBACH, H; BROT, N. Escherichia coli peptide methionine sulfoxide reductase gene: regulation of expression and role in protecting against oxidative damage. Proceedings of The National Academy Of Sciences Of The United States Of America, v.93, n.8, p.3205-3208, 1996.

MOSKOVITZ J.; RAHMAN M.A.; STRASSMAN J.; YANCEY S.O.; KUSHNER S.R.; BROT N.; WEISSBACH H. Escherichia coli peptide methionine sulfoxide reductase gene: Regulation of expression and role in protecting against oxidative damage. Journal of Bacteriology, v.177, n.3, p.502-507, 1995.

MULLER, U; TENBERGE, K.B.; OESER, B.; TUDZYNSKI, P. Cell, probably encoding a cellobiohydrolase lacking the substrate binding domain, is expressed in the initial infection phase of Claviceps purpurea on Secale cereale. Molecular Plant Microbe Interactions, v. 10, n.2, p.268-279, 1997. 
NARAYAN, S.; GREIF, K.F. Transport of a synaptotagmin-YFP fusion protein in sympathetic neurons during early neurite outgrowth in vitro after transfection in vivo. Journal of Neuroscience Methods, v. 133, n. 1/2, p. 91-98, 2004.

SILVA NETO, J.F.; KOIDE, T.; GOMES, S.L.; MARQUES, M.V. Site-directed gene disruption in Xylella fastidiosa. FEMS Microbiology Letters, v.210, n.1, p.105$110,2002$.

NEWMAN, K.L.; ALMEIDA, R.P.P.; PURCELL, A.H.; LINDOW, S.E. Cell-cell signaling controls Xylella fastidiosa interactions with both insects and plants. Proceedings Of The National Academy Of Sciences Of The United States Of America, v. 101, n.6, p.1737-1742, 2004.

NORMANDER, B.; HENDRIKSEN, N.B.; NYBROE, O. Green fluorescent proteinmarked Pseudomonas fluorescens: localization, viability, and activity in the natural barley rhizosphere. Applied and Environmental Microbiology, v.65, n.10, p.4646-4651, 1999.

NORMAN-SETTERBLAD, C.; VIDAL, S.; PALVA, E.T. Interacting signal pathways control defense gene expression in Arabidopsis in response to cell wall-degrading enzymes from Erwinia carotovora. Molecular Plant Microbe Interactions, v.13, n. 4, p. $430-438,2000$.

NOWAK, K.; LUNIAK, N.; MEYER, S.; SCHULZE, J.; MENDEL, R.R.; HANSCH, R. Fluorescent proteins in poplar: a useful tool to study promoter function and protein localization. Plant Biology, v.6, n.1, p.65-73, 2004.

NUNES, L.R.; ROSATO, Y.B.; MUTO, N.H.; YANAI, G.M.; DA SILVA, V.S.; LEITE, D.B.; GONCALVES, E.R.; DE SOUZA, A.A.; COLETTA-FILHO, H.D.; MACHADO, M.A.; LOPES, S.A.; DE OLIVEIRA, R.C. Microarray analyses of Xylella fastidiosa provide evidence of coordinated transcription control of laterally transferred elements. Genome Research, v.13, n.4, p.570-578, 2003.

PEREZ, S.; MAZEAU, K.; HERVE DU PENHOAT, C. The three-dimensional structures of the pectic polysaccharides. Plant Physiology and Biochemistry, v.38 n. $1 / 2$, p. $37-55,2000$. 
SCARPARI, L.M. Modulação da expressão de genes de patogenicidade putativos em Xylella fastidiosa sob condições de baixa e alta densidade celular. Piracicaba, 2001. 72p. Dissertação (Mestrado) - Escola Superior de Agricultura "Luiz de Queiroz", Universidade de São Paulo.

SEXTON, A.C.; PAULSEN, M.; WOESTEMEYER, J.; HOWLETT, B.J. Cloning, characterization and chromosomal location of three genes encoding host-cell-walldegrading enzymes in Leptosphaeria maculans, a fungal pathogen of Brassica spp. Gene, v.248, n.1/2, p.89-97, 2000.

SHEN, J.; HSU, C.M.; KANG, B.K.; ROSEN, B.P.; BHATTACHARJEE, H. The Saccharomyces cerevisiae Arr4p is involved in metal and heat tolerance. Biometals, v. 16, n.3, p.369-378, 2003.

SHERALD, J.L.; KOSTKA, S.J. Bacterial leaf scorch of landscape trees caused by Xylella fastidiosa. Journal of Arboriculture, v.18, n.1, p.57-63, 1992.

SHERALD, J.L.; WELLS, J.M; HURTT, S.S.; KOSTKA, S.J. Association of fastidious, xylem-inhabiting bacteria with leaf scorch in red maple. Plant Disease, v.71, p.930-933, 1987.

SILVA NETO, J.F.; KOIDE, T.; GOMES, S.L.; MARQUES, M.V. Site-directed gene disruption in Xylella fastidiosa. FEMS Microbiology Letters, v.210, n.1, p.105$110,2002$.

SILVA, F.R.; VETTORE, A.L.; KEMPER, E.L.; LEITE, A.; ARRUDA, P. Fastidian gum: the Xylella fastidiosa exopolysaccharide possibly involved in bacterial pathogenicity. FEMS Microbiology Letters, v.203, n.2, p.165-171, 2001.

SIMPSON, A.J.G; REINACH, F.C.; ARRUDA, P. et al. The genome sequence of the plant pathogen Xylella fastidiosa. Nature, v.406, n.6792, p.151-157, 2000.

SLATER, H.; ALVAREZ-MORALES, A.; BARBER, C.E.; DANIELS, M.J.; DOW, J.M. A two-component system involving an HD-GYP domain protein links cell-cell signalling to pathogenicity gene expression in Xanthomonas campestris. Molecular Microbiology, v.38, n.5, p.986-1003, 2000. 
TANG, J.L.; LIU, Y.N.; BARBER, C.E.; DOW, J.M.; WOOTTON, J.C.; DANIELS, M.J. Genetic and molecular analysis of a cluster of $r p f$ genes involved in positive regulation of synthesis of extracellular enzymes and polysaccharide in Xanthomonas campestris pathovar campestris. Molecular and General Genetics, v.226, n.3, p.409-417, 1991.

TAYLOR, A.B.; BENGLIS D.M.J.; DHANDAYUTHAPANI, S.; HART, P.J. Structure of Mycobacterium tuberculosis methionine sulfoxide reductase A in complex with protein-bound methionine. Journal of Bacteriology, v.185, n.14, p.4119-4126, 2003.

TEERI, T.T. Crystalline cellulose degradation: New insight into the function of cellobiohydrolases. Trends in Biotechnology, v.15, n.5, p.160-167, 1997.

TSE, Y.C.; MO, B.; HILLMER, S.; ZHAO, M.; LO, S.W.; ROBINSON, D.G.; JIANG, L. Identification of multivesicular bodies as prevacuolar compartments in Nicotiana tabacum BY-2 cells. The Plant Cell, v.16, n.3, p.672-693, 2004.

TYSON, G.E.; STOJANOVIC, B.J.; KUKLINSKI, R.F.; DIVITTORIA, T.J.; SULLIVAN, M.L. Scanning electron microscopy of Pierce's disease bacterium in petiolar xylem of grape leaves. Phytopathology, v.75, n.3, p.264-269, 1985.

VAN SLUYS, M.A.; DE OLIVEIRA, M.C.; MONTEIRO-VITORELLO, C.B. et al. Comparative analyses of the complete genome sequences of Pierce's disease and citrus variegated chlorosis strains of Xylella fastidiosa. Journal of Bacteriology, v.185, n.3, p.1018-1026, 2003.

VAN SLUYS, M.A.; MONTEIRO-VITORELLO, C.B.; CAMARGO, L.E.; MENCK, C.F.; DA SILVA, A.C.; FERRO, J.A; OLIVEIRA, M.C.; SETUBAL, J.C.; KITAJIMA, J.P.; SIMPSON, A.J. Comparative genomic analysis of plantassociated bacteria. Annual Review of Phytopathology, v.40, p. 169-189, 2002.

VRIES, R.P.; VISSER, J. Aspergillus enzymes involved in degradation of plant cell wall polysaccharides. Microbiology and Molecular Biology Reviews, v.65, n.4, p.497-522, 2001.

WALton, J. D. Deconstructing the cell wall. Plant Physiology, v.114, n.4, p.11131118, 1994. 
WEISSBACH, H.; ETIENNE, F.; HOSHI, T.; HEINEMANN, S.H.; LOWTHER, W.T.; MATTHEWS, B.; ST JOHN, G.; NATHAN, C.; BROT, N. Peptide methionine sulfoxide reductase: structure, mechanism of action, and biological function. Archives of Biochemistry and Biophysics, v.397, n.2, p.172-178, 2002.

WELLS, J.M.; RAJU, B.C.; JUNG, H.Y; WEISBURG, W.G.; MANDELCO-PAUL, L.; BRENNER, D.J. Xylella fatidiosa gen nov., sp. nov. gram negative, xylem limited fastidious plant bacteria related to Xanthomonas spp. International Journal of Systematic Bacteriology, v.37, n.2, p.136-143, 1987.

WELLS, J.M.; RAJU, B.C.; NYLAND, G. Isolation, culture, and pathogenicity of the bacterium causing phony disease of peach. Phytopathology, v.73, p.859-862, 1983.

WELLS, J.M; WAVER, D.J.; RAJU, B.C. Distribution of rickettsia-like bacteria in peach, and their ocurrence in plum, cherry, and some perennial weeds. Phytopathology, v.70, p.817-820, 1980.

WILSON, D.B. Studies of Thermobifida fusca plant cell wall degrading enzymes. The Chemical Record, v.4, n.2, p.72-82, 2004.

WILSON, T.J.G.; BERTRAND, N.; TANG, J.L.; FENG, J.X.; PAN, M.Q.; BARBER, C.E.; DOW, J.M.; DANIELS, M.J. The rpfA gene of Xanthomonas campestris pathovar campestris, which is involved in the regulation of pathogenicity factor production, encodes an aconitase. Molecular Microbiology, v.28, n.5, p.961-970, 1998.

WIZEMANN, T.M.; MOSKOVITZ, J.; PEARCE, B.J.; CUNDELL, D.; ARVIDSON, C.G.; SO, M.; WEISSBACH, H.; BROT, N.; MASURE, H.R. Peptide methionine sulfoxide reductase contributes to the maintenance of adhesins in three major pathogens. Proceedings Of The National Academy Of Sciences Of The United States Of America, v.93, n. 15, p.7985-7990, 1996.

WULFF, N.A. Caracterização enzimática das celulases Xf-810, Xf-818 e Xf-2708 de Xylella fastidiosa e purificação da proteína Xf-818, expressas em Escherichia coli. Piracicaba, 2002. 196p. Tese (Doutorado) - Escola Superior de Agricultura "Luiz de Queiroz", Universidade de São Paulo. 
WULFF, N.A.; CARRER, H.; PASCHOLATI, S.F. Cloning and expression of cellulose XF-818 of Xylella fastidiosa in Escherichia coli. Scientia Agricola, v.60, n.4, p.715-721, 2003.

XI, C.; LAMBRECHT, M.; VANDERLEYDEN, J.; MICHIELS, J. Bi-funcional $g f p$ and gusA-containing mini-Tn5 transposon derivatives for combined gene expression and bacterial localization studies. Journal of Microbiological Methods, v.35, n.1, p.85-92, 1999.

YAKOBY, N.; BENO-MOUALEM, D.; KEEN, N.T.; DINOOR, A.; PINES, O.; PRUSKY, D. Colletotrichum gloeosporioides pelB is an important virulence factor in avocado fruit-fungus interaction. Molecular Plant Microbe Interactions, v.14, n. 8, p.988-995, 2001.

YAMAMOTO, P.T.; ROBERTO, S.R.; PRIA JÚNIOR, W.D.; FELIPPE, M.R.; MIRANDA, V.S.; TEIXEIRA, D.C.; LOPES, J.R.S. Trasmissão de Xylella fastidiosa pelas cigarrinhas Homalodisca ignorata, Acrogonia virescens e Molomea cincta (Hemíptera: Cicadellidae) em plantas cítricas. Summa Phytopathologica, v.26, n.1, Supl. p.128, 2000. Suplemento.

YERMOLAIEVA, O.; XU, R.; SCHINSTOCK, C.; BROT, N.; WEISSBACH, H.; HEINEMANN, S.H.; HOSHI, T. Methionine sulfoxide reductase A protects neuronal cells against brief hypoxia/reoxygenation. Proceedings Of The National Academy Of Sciences Of The United States Of America, v.101, n.5, p.1159-1164, 2004. 